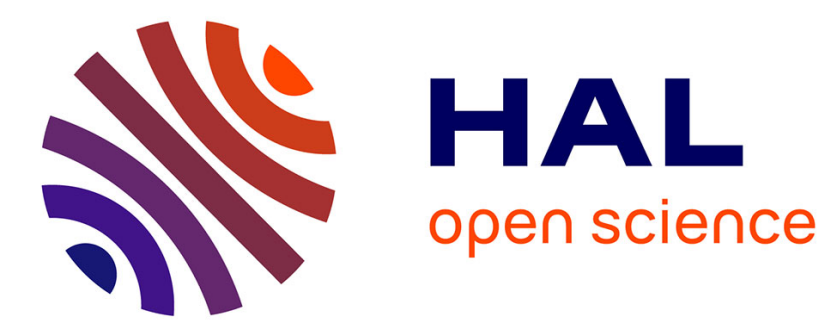

\title{
Mass accumulation rates in Asia during the Cenozoic
}

François Métivier, Yves Gaudemer, Paul Tapponnier, Michel Klein

\section{To cite this version:}

François Métivier, Yves Gaudemer, Paul Tapponnier, Michel Klein. Mass accumulation rates in Asia during the Cenozoic. Geophysical Journal International, 1999, 137 (2), pp.280-318. hal-00987908

\section{HAL Id: hal-00987908 \\ https: / hal-univ-paris.archives-ouvertes.fr/hal-00987908}

Submitted on 4 Apr 2017

HAL is a multi-disciplinary open access archive for the deposit and dissemination of scientific research documents, whether they are published or not. The documents may come from teaching and research institutions in France or abroad, or from public or private research centers.
L'archive ouverte pluridisciplinaire HAL, est destinée au dépôt et à la diffusion de documents scientifiques de niveau recherche, publiés ou non, émanant des établissements d'enseignement et de recherche français ou étrangers, des laboratoires publics ou privés. 


\title{
Mass accumulation rates in Asia during the Cenozoic
}

\author{
François Métivier, ${ }^{1}$ Yves Gaudemer, ${ }^{1}$ Paul Tapponnier ${ }^{1}$ and Michel Klein ${ }^{2}$ \\ ${ }^{1}$ Laboratoire de Tectonique, Mécanique de la Lithosphère, UMR 7578, Institut de Physique du Globe de Paris, 4 place Jussieu, 75252 Paris Cedex 05 , \\ France.E-mail:metivier@ipgp.jussieu.fr \\ ${ }^{2}$ Tour TOTAL, 24 cours michelet, Cedex 47, 92069 La Défense, France
}

Accepted 1998 November 6. Received 1998 September 14; in original form 1998 March 11

\begin{abstract}
SUMMARY
This work establishes estimates of mass accumulation rates in 18 mostly offshore sedimentary basins in Asia since the beginning of the Cenozoic, $\approx 66 \mathrm{Ma}$. The estimates were derived from isopach maps, cross-sections and drill holes or stratigraphic columns assuming regional similarity of the strata. Average solid phase volumes and accumulation rates were calculated for nine epochs approximately corresponding to geological periods: Palaeocene $(\approx 66-58 \mathrm{Ma})$, Eocene $(\approx 58-37 \mathrm{Ma})$, Oligocene $(\approx 37-30$ and $30-24 \mathrm{Ma})$, Miocene $(\approx 24-17,17-11$ and $11-5 \mathrm{Ma})$, Pliocene $(\approx 5-2 \mathrm{Ma})$ and Quaternary $(\approx 2-0 \mathrm{Ma})$. These rates shed new light on the geological history of Asia since the onset of the collision of India with Asia $(\approx 50 \mathrm{Ma})$. The overall average accumulation rates curve for Asian sedimentary basins since the beginning of the Tertiary shows an exponential form with slow accumulation rates (less than $0.5 \times 10^{6} \mathrm{~km}^{3} \mathrm{Myr}^{-1}$ ) until the beginning of the Oligocene, more than $15 \mathrm{Myr}$ after the onset of the collision. From the Oligocene onwards rates increase quickly in an exponential manner, reaching their maximum values in the Quaternary (more than $1.5 \times 10^{6} \mathrm{~km}^{3} \mathrm{Myr}^{-1}$ ). From these observations we suggest that extrusion and crustal shortening are complementary processes that have been successively dominant throughout the India-Eurasia collision history. At smaller scales one may distinguish between independent histories at the subcontinental and basin scales. This permits a comparison of the relative importance of tectonic and climatic erosion processes affecting the different mountain belts of Asia during the Cenozoic.
\end{abstract}

Key words: accumulation rates, Asia, Cenozoic, mass balance, sedimentary basins.

\section{INTRODUCTION}

What is the importance of erosion in the mechanisms of mountain building? During the last decade, analysis of morphology has proven to be a useful tool to study active tectonics in various regions of the world (e.g. Hanks et al. 1984; Weldon \& Sieh 1985; Armijo et al. 1986, 1989; Tapponnier et al. 1990; Gaudemer et al. 1995). Measurements of vertical and horizontal movements of dated morphological markers permit quantification of the average movement along the faults that border every active mountain range. Most of the time these morphological markers have been subjected to alteration and erosion so that the problem of decorrelating the respective influences of tectonics and erosion arises. At the scale of a mountain range, the problem is not very different. A mountain range is nothing but a marker of the long-term tectonic activity in a given region of the planet. Uplift and building of mountain belts along thrust ramps accommodate the shortening induced by the convergence of two crustal blocks. Stacking of mass and growth of relief leads to a rise of the potential energy stored in the range, whereas erosion, removing mass and lowering the elevation, counteracts the effects of uplift and reduces the potential energy of the system. This simple scheme should then lead us to conclude that tectonics is responsible for mountain building, while erosion, rearranging the stored masses, sometimes extremely rapidly (Leeder 1991; Burbank et al. 1996), reshapes the ranges and, in the end, destroys them.

This view does not encounter uniform agreement. Some have proposed that if erosion, on average, leads to a reduction of the average elevation (long-period in space) it can induce uplift of mountain peaks (short-period in space) through the incision of deep valleys because of the regional nature of the isostatic response to local unloading (e.g. Molnar \& England 1990; Montgomery 1994). Others argue that if tectonics were much more efficient or rapid than erosion, it should induce the formation of broad high plateaux eroded only on their borders, as for example is the case with Tibet. It could then also contribute to the local uplift of mountain peaks (Masek et al. 1994). Others even propose erosion as the driving mechanism that supports existing mountain belts, assuming Couette-type 
flow of a Newtonian fluid-like lower crust (Avouac \& Burov 1996). Under dynamic equilibrium conditions, erosion could keep the deformation localized and prevent the mountain range from collapsing. The question of the relation between tectonics and erosion remains unaddressed because of the lack of quantitative data that would enable us to fix the boundary conditions and even the mechanics of the problem with any certainty. Several conceptual models estimate the erosion of drainage areas. Depending on the scale, alteration and transport are modelled as diffusive, proportional to the height, to the slope or to physiographic parameters of the drainage basin and can even incorporate thresholds. Two conceptually different approaches have so far been developed in geomorphology. The first, experimental in nature, relies either on the statistical analysis of data sets (e.g. Fournier 1960; Ahnert 1970; Pinet \& Souriau 1988; Summerfield \& Hulton 1994) or on the analysis of small-scale models in the field or in the laboratory (e.g. Schumm et al. 1987; Howard \& Kerby 1983; Buffalo 1989; Meunier 1995). Other conceptual approaches have been developed that combine the different mechanisms that contribute to the evolution of a pre-existing topography into a general geomorphological evolution model (e.g. Willgoose et al. 1991; Tucker \& Slingerland 1994; Kooi \& Beaumont 1994). In these models erosion is mainly modelled as a coupled diffusive-advective transport system. Efforts to model the mechanisms of erosion concentrate on the analysis of topography to distinguish between tectonic and topographic signals.

Quantifying the importance of the different parameters inducing the formation of a topography implies that in the end one is able to establish the balance of mass transfers at any point during any given time interval (e.g. Hay et al. 1989). Complexity of the balance depends on the scale at which one looks at the problem. Mountain ranges, because they are the sites of many interactions, are not well suited for mass-balance studies. Sedimentary basins are where the products or erosion of the related reliefs accumulate. They offer the possibility of quantifying the fluxes leaving the drainage basins over long periods. Some basins are not subjected to compressive deformation; others are not affected by any deformation at all. They are mostly located at the periphery of mountain ranges and collect detrital material eroded during the mountain building process. They can experience long periods of average stability and therefore carry very long sedimentary records. It is then possible to determine the volume that accumulated and therefore the mass fluxes resulting from erosion of a growing mountain range during its tectonic build-up. It should then be possible to place constraints on the mechanical processes taking place upstream in the mountain range.

We address this problem in the context of the collision of India with Asia and present estimates of mass accumulation rates in the major Cenozoic basins surrounding the collision zone (Fig. 1). The collision, the age of which is still a matter of debate (e.g. Jaeger et al. 1990; Beck et al. 1995), has induced major deformation of the Asian crust since 50 Ma (Patriat \& Achache 1984; Besse et al. 1984): uplift of the Himalayas, the Pakistan ranges, the Makran, the Indoburman ranges, the Tien Shan and Tibet. The collision also seems to have induced deformation in the Altai and the Baikal region to the north (e.g. Molnar \& Tapponnier 1975; Tapponnier \& Molnar 1977, 1979). Lateral movements of crustal blocks, also termed extrusion (e.g. Tapponnier et al. 1986), have been the subject of a major argument in the scientific community. This debate leads to different histories of the Tertiary deformation of Asia since the onset of the collision (e.g. England \& Houseman 1986, 1988; Tapponnier et al. 1986; Peltzer \& Tapponnier 1988; Burchfiel et al. 1991; Le Pichon et al. 1992; Avouac \& Tapponnier 1993; Molnar et al. 1993; Leloup et al. 1995; Peltzer \& Saucier 1996) that especially concern the timing and magnitude of events. More and more data sets suggest the existence of significant extrusion (e.g. Yang \& Besse 1993; Leloup et al. 1995), although the quantitative partitioning of the India-Asia shortening between crustal thickening, extrusion, possibly continental subduction (Mattauer 1986), and erosion is still a matter of debate (Tapponnier et al. 1986; Le Pichon et al. 1992; Molnar et al. 1993; Leloup et al. 1995; Peltzer \& Saucier 1996).

Asia bears many advantages as a field of study, among them the scale of the deformation, which should result in clear quantitative signals in the geological record. It also poses a certain number of special problems such as the formation of the Tibetan highs and the evolution of the monsoonal climate. The formation of exceptional relief such as Tibet or the east-west-trending Himalaya induces profound perturbation of the Hadley circulation in the Northern Hemisphere (Chen \& Trenberth 1988; Kutzbach et al. 1989). This perturbation of zonal circulation causes climatic variations on either side of the relief, especially in the average annual precipitation balance (Prell et al. 1992). This may perhaps induce quantitative changes in the sedimentary record (Burbank et al. 1993). The timing and cause of the rise of Tibet is also a matter of debate. Multiple hypotheses have been proposed to explain the uplift of the largest and highest plateau on earth, including delamination of the lower crust (Bird 1978, 1979), injection of the Indian crust into the weaker Asian crust (Zhao \& Morgan 1985), buckling of a multilayered lithosphere (Jin et al. 1994; Burg et al. 1995), plastic deformation of the Asian crust modelled as a Newtonian viscous fluid (England \& McKenzie 1982; England \& Houseman 1986), very rapid uniform uplift of Tibet at $8 \mathrm{Ma}$ because of the sinking of a part of the lithospheric root underlying the plateau (Molnar et al. 1993), or propagation of shortening along thrust fronts that branch from the Altyn Tagh fault at least in the NE of Tibet (Tapponnier et al. 1990; Métivier et al. 1998; Meyer et al. 1998).

Whatever the mechanisms, throwing light on the Cenozoic history of Asia implies solving these two problems. Massbalanced reconstruction of the volumes stored in the sedimentary basins of Asia should enable us to impose constraints on the mechanisms and timing of deformation in Asia since the onset of collision $50 \mathrm{Ma}$. We shall first describe the nature of sedimentation during the Cenozoic in the main sedimentary basins of Asia, with the exception of sedimentary basins of central Asia that have been reported elsewhere (Métivier \& Gaudemer 1997; Métivier et al. 1998). We then explain the technique we developed to estimate the mass accumulation rates curve by reconstructing the thicknesses of sediments that accumulated. Finally, we present and discuss our results.

\section{GEOLOGY OF THE BASINS}

In this section we briefly summarize the main stratigraphic features of the Cenozoic sedimentary basins. This description constitutes a general basis for the discussion of accumulation rates presented in the next sections. We shall focus only on the 


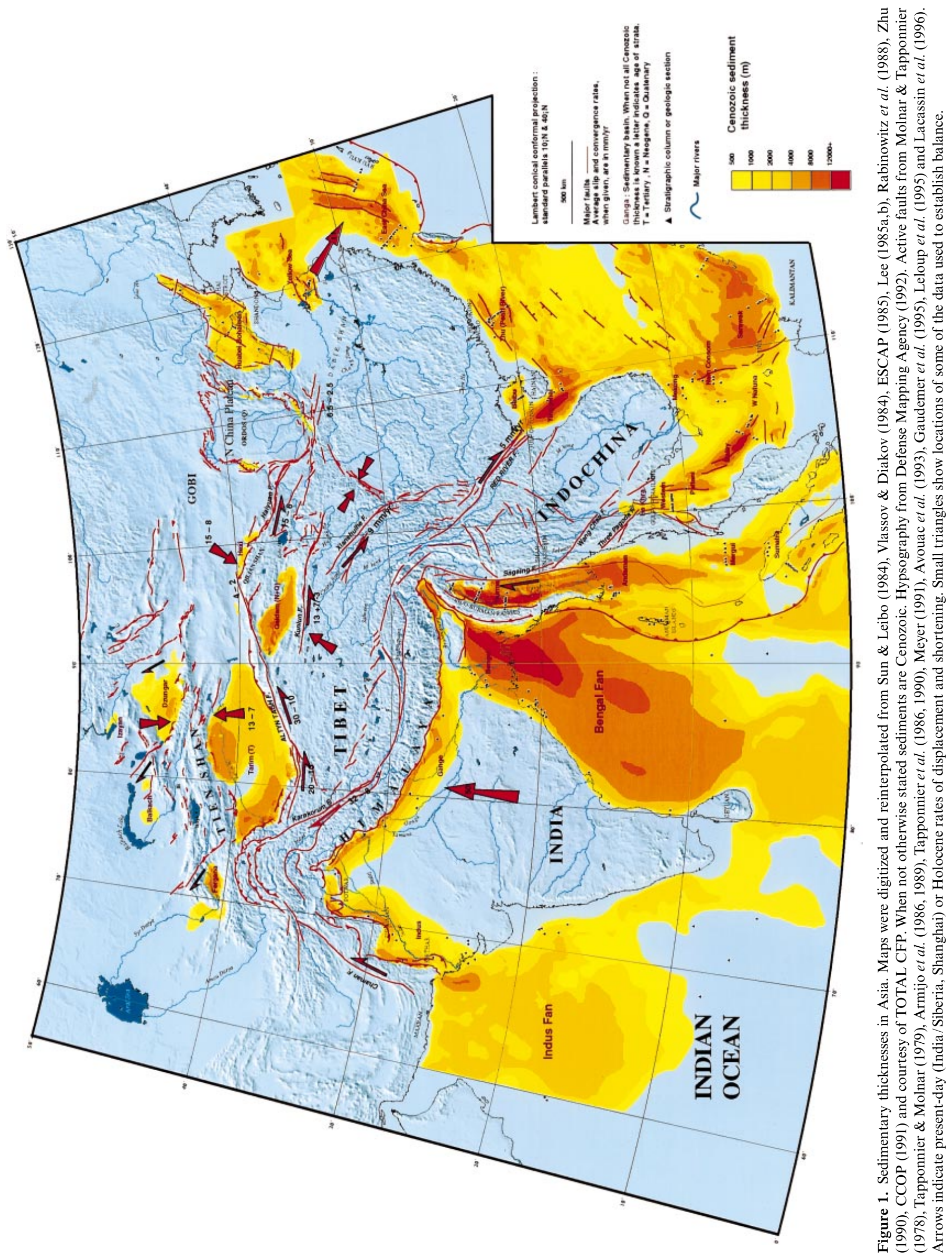


Tertiary and Quaternary history of these basins related to the India-Asia collision, even though some of them have experienced sedimentation since the Palaeozoic. Data sources are referenced in Table 1. Three types of data were used to reconstruct the mass balance: isopach maps, drill logs or stratigraphic columns, and cross-sections. The isopach maps were first digitized and regrided on a $5^{\prime}$ of arc numerical grid extending from $55^{\circ} \mathrm{E}$ to $130^{\circ} \mathrm{E}$ and from 0 to $50^{\circ} \mathrm{N}$ to compute Fig. 1 (Fig. 2 shows the data points we sampled and used to produce the map shown in Fig. 1). With the exception of the basins of continental China, the isopachs represent thicknesses of total Cenozoic sediments. Because of the uncertainty in the dating of clastic continental materials, it is possible that some Mesozoic sediment is included in the volume. The uncertainty in this database is of the order of $1000 \mathrm{~m}$ (one contour interval on the original maps). Further data and cross-sections can be found in the references included in the general stratigraphic description of the Cenozoic basins of Asia. In order to provide a summary of accumulation patterns in different parts of the basins we present cumulative thickness/age curves for each basin (references are listed in Table 1) in the course of the description. Sediment thicknesses given in this section come from drill logs (hereafter referred to as DLs) or stratigraphic sections onland. They may be lower than the real maximum values of stratal thickness determined from seismic profiling. Table 2 provides a summary of the sedimentary environments and nomenclature in Asia during the Cenozoic. This simplified description should allow rapid cross-correlations between sedimentary basins, and may be useful when we analyse the results. We summarize the technique of reconstruction (developed in Métivier \& Gaudemer 1997) before discussing the results.

\subsection{Basins located east of continental China}

\subsubsection{The Hubei-Bohai basin, mouth of the Huang He}

This basin, extending from longitude $112.5^{\circ} \mathrm{E}$ to $124^{\circ} \mathrm{E}$ and latitude $35^{\circ} \mathrm{N}$ to $42^{\circ} \mathrm{N}$, covers an area of approximately $200000 \mathrm{~km}^{2}$ (Figs 1 and 3a). It is in part continental and in part extends into the Gulf of Bohai. The basin is limited to the west by the foothills of the North China Plateau, to the south by the Dabie Shan and to the east by the Shandong and Bohai strait. To the north the Bohai Bay extends to the alluvial plain of the Liao He. There is no clear topographic boundary between the Hubei basin and the Subei basin located south and west of the Shandong, which was also fed by the Huang He in the Quaternary. The basin basement is dated around $1700 \mathrm{Ma}$ and a description of the pre-Cenozoic history may be found in Zhang (1985), Ye et al. (1985) and $\mathrm{Hu}$ et al. (1989). The Palaeocene, up to $1700 \mathrm{~m}$ thick in DLs and apparently a time of reduced sedimentation, is often cited as a period of resurgent tectonic activity in the basin (Ye et al. 1985; Zhang 1985). From the Eocene onwards, extensional tectonics and subsidence developed, with activation of east-west strike-slip faults that offset the grabens forming the depocentres. Sedimentation was detrital, in a continental environment (Zhang 1985). During the Neogene subsidence clearly affected the entire depositional area. Thicknesses recorded in DLs are up to $2700 \mathrm{~m}$ and average 1000-1500 m. All types of sediments may be found in the Palaeogene series: clastics (sands or shales), limestones and even dolomitic intercalations. Three units are commonly distinguished: the Kongdian, Shahejie and Dongying units. Ages are well constrained by the radiometric dating of volcanic ashes intercalated in the sediments (Ye et al. 1985). Cyclicity of

Table 1. Database used to derive the mass balance reconstitution of accumulation rates in Asia; the basins of Central Asia are described elsewhere (Métivier \& Gaudemer 1997; Métivier et al. 1998).

\begin{tabular}{|c|c|c|c|c|}
\hline Basin & $\begin{array}{l}\text { Drill hole or } \\
\text { stratigraphic section }\end{array}$ & Cross-section & Isopach maps & Sources \\
\hline Andaman & 31 & & 1 & TOTAL CFP; CCOP (1991) \\
\hline Beibu & & 1 & 1 & CCOP (1991) \\
\hline Bengal & 60 & 4 & 2 & $\begin{array}{l}\text { TOTAL CFP; Rabinowitz et al. 1988; Reimann 1993; Cochran \& } \\
\text { Stow (1989); Van der Borsch et al. (1974); Lindsay et al. } 1991\end{array}$ \\
\hline Burma & & 4 & 1 & TOTAL CFP \\
\hline East China & 9 & 1 & 2 & Sun \& Leibo (1984) \\
\hline Dzungar & & 1 & 1 & Sun \& Leibo (1984) \\
\hline Ganga & 8 & 1 & 1 & TOTAL CFP; Acharyya \& Ray (1982); Sastri et al. 1971 \\
\hline G. of Thailand & 3 & 2 & 2 & CCOP (1991); Hamilton (1979); Pradidtan \& Dook (1992) \\
\hline Hexi & 4 & & 1 & Sun \& Leibo (1984); TOTAL CFP \\
\hline Bohai & 52 & & 3 & Sun \& Leibo (1984); Zhu (1990); CCOP (1991); ESCAP (1985) \\
\hline Indus & 26 & & 3 & TOTAL CFP; Geol. map of Pakistan; Whitmarsh et al. (1974) \\
\hline Malay & & 2 & 2 & ASCOPE (1981); CCOP (1991); TOTAL CFP; Hamilton (1979) \\
\hline Mekong & 41 & 1 & 2 & TOTAL CFP; CCOP (1991); Hamilton (1979) \\
\hline Mergui & & 1 & 1 & CCOP (1991) \\
\hline Qaidam & 8 & & 4 & ESCAP (1985); Sun \& Leibo (1984) \\
\hline Qong Dong Nan & 9 & & 2 & Sun \& Leibo (1984); TOTAL CFP; ESCAP (1985) \\
\hline Sabah & & 1 & 2 & CCOP (1991); Hamilton (1979) \\
\hline Sarawak & & 1 & 2 & CCOP (1991); Hamilton (1979) \\
\hline Sibolga & & 1 & 1 & CCOP (1991) \\
\hline Subei & 19 & 1 & 2 & CCOP (1991); Sun \& Leibo (1984) \\
\hline N. Sumatra & & 1 & 1 & CCOP (1991) \\
\hline Tarim & 6 & & 2 & ESCAP (1985); Lee (1985a) \\
\hline Yinggehai & 52 & 2 & 2 & TOTAL CFP; CCOP (1991); Sun \& Leibo (1984) \\
\hline Zhu & 5 & 1 & 2 & TOTAL CFP; CCOP (1991); Sun \& Leibo (1984); ESCAP (1985) \\
\hline
\end{tabular}




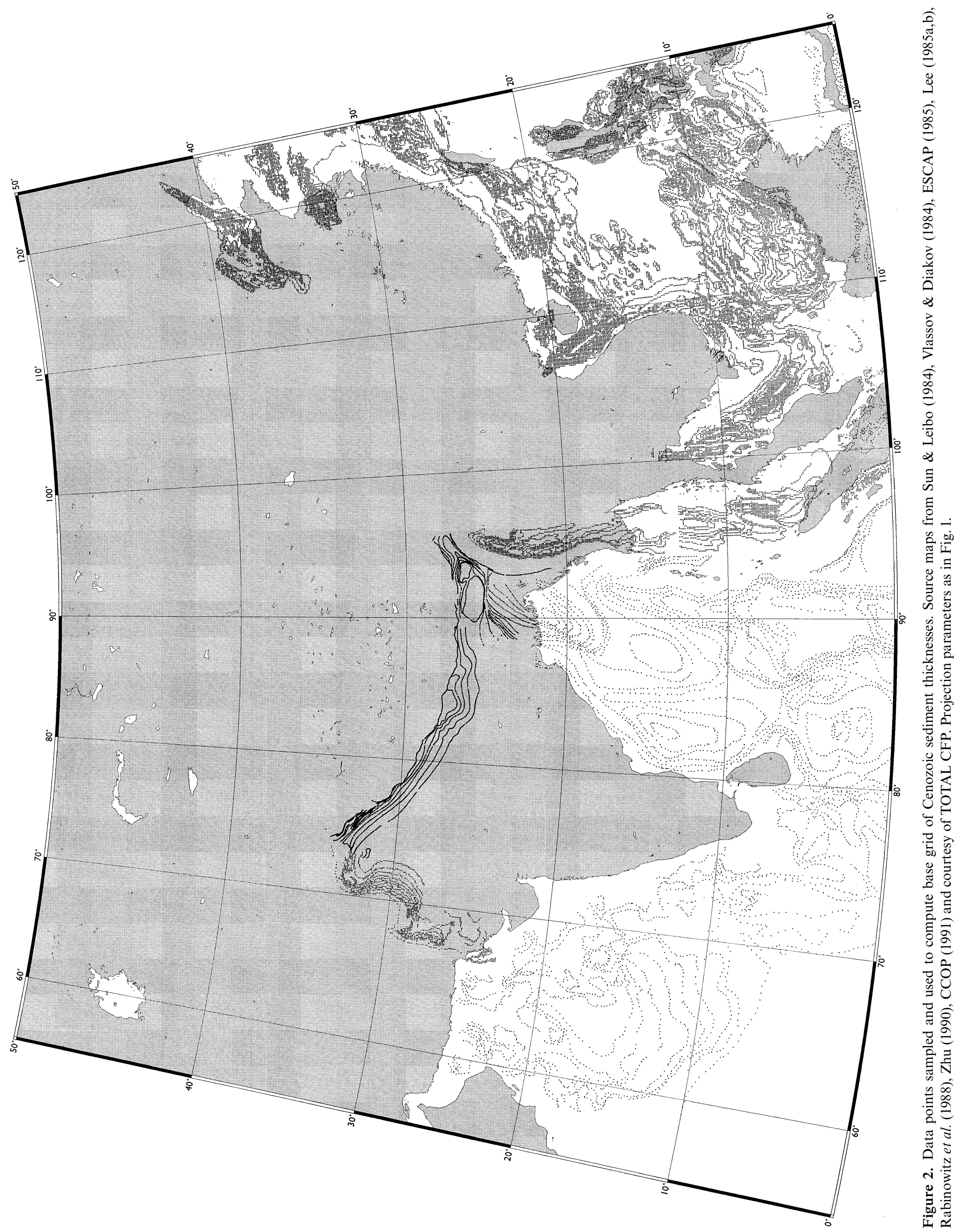


Table 2. Simplified stratigraphic correlation chart in Asia. Stratigraphic formations are given in italics. NN indicates no formation name exists or was found in the literature. Shading indicates whether deposition environment was predominantly marine (deep grey), continental (medium grey) or alternating (light grey)

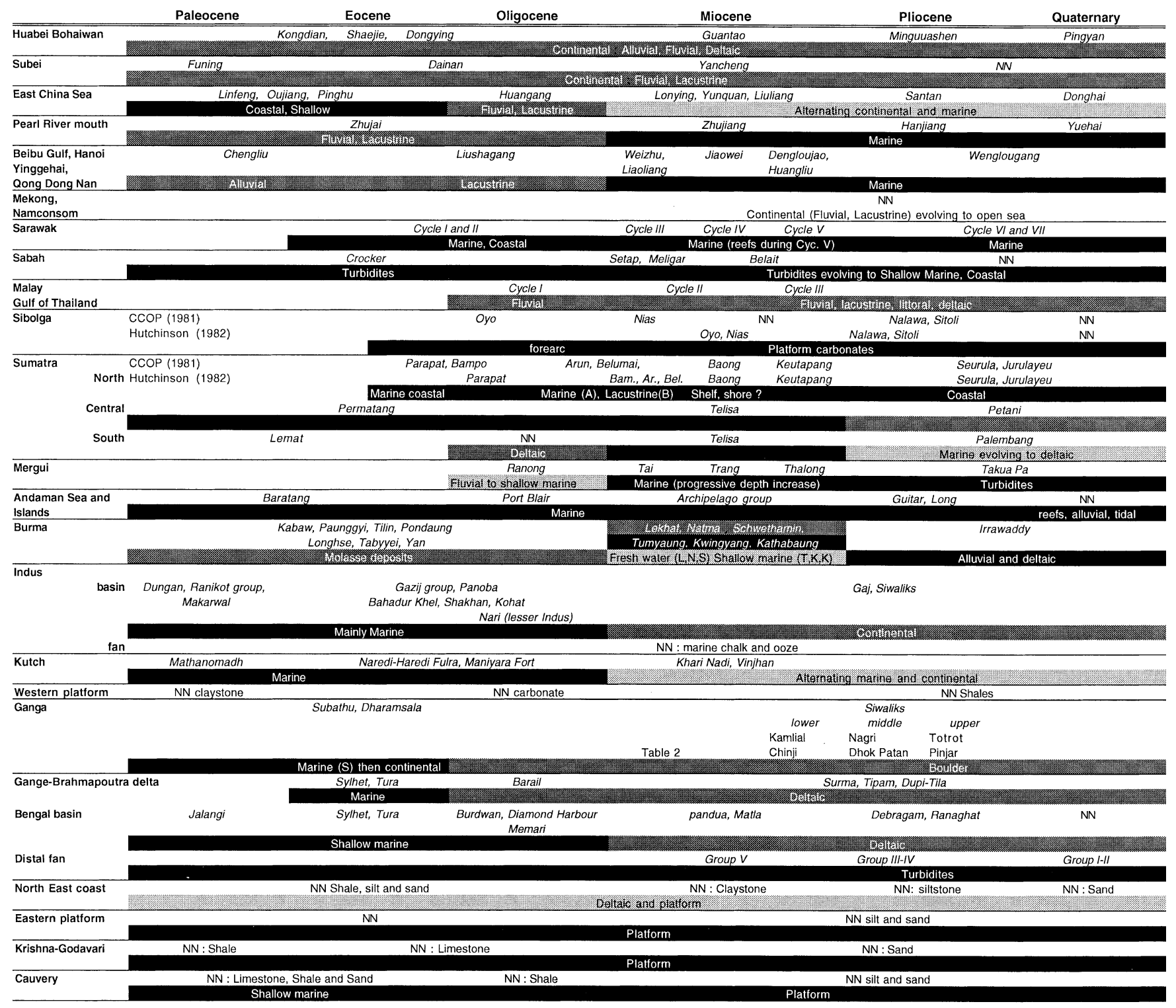

the deposits is also evident but the number of cycles varies between authors (Ye et al. 1985; Zhang 1985). The depositional environment was continental, ranging from lacustrine (Zhang 1985) to alluvial, fluvial and even deltaic (Zhang 1985). The Neogene and Quaternary strata that unconformably overlie the older deposits are divided into three sequences: Guantao, Minghuashen and Pingyuan (see Zhang 1985, Table 1 for a complete description).

\subsubsection{Subei and Yellow Sea basins}

This triangle-shaped basin lies one third on the continent and two-thirds in the Yellow Sea (Figs 1 and 3b). It extends south and east of the Shandong to the Dabie Shan and is known as one of the historical and geological mouths of the Huang He. The present-day sedimentation area covers $100000 \mathrm{~km}^{2}$. Sedimentation has been continuous throughout the Tertiary and Quaternary. DL Cenozoic thickness is up to $3600 \mathrm{~m}$. The depositional environments were fluvial and lacustrine. Four main formations are encountered from the Palaeocene to the Miocene: the Funing (Palaeocene), the Dainan (EoceneOligocene), the Yancheng (Miocene) and the Plio-Quaternary (Zhao et al. 1985).

\subsubsection{The East China Sea basin, mouth of the Chang Jiang}

The East China Sea extends south from the Yellow Sea with continental China on the west and the Ryu Kyu archipelago (Japan) on the east and to Taiwan to the south (Figs 1 and 3c). It extends over an area of $800000 \mathrm{~km}^{2}$ and is the outlet of the Chang Jiang (Yang Tzi or Blue River). Two major Cenozoic basins developed there diachronously: the East China Sea margin basin (ECS) and the Okinawa basin. The basement of both is Proterozoic (1.68 Ga according to Zhou et al. 1989) 

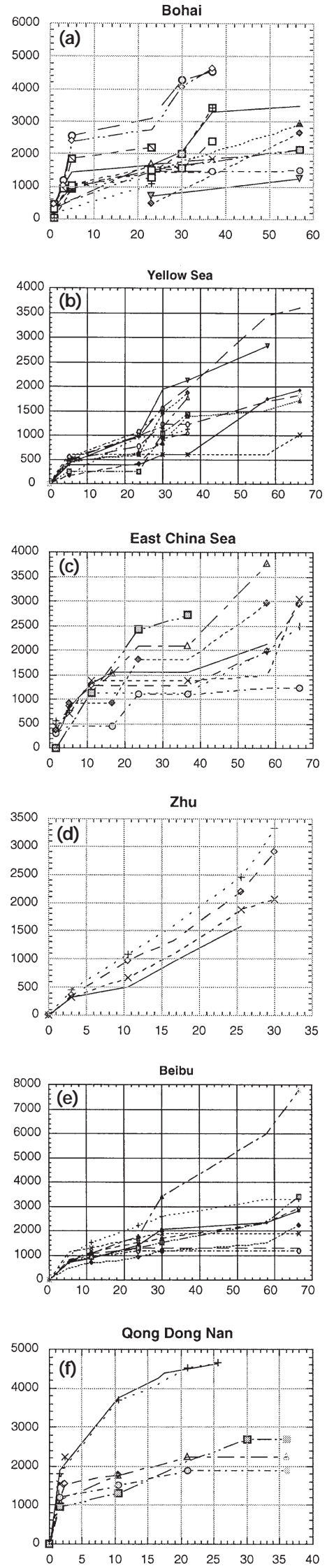
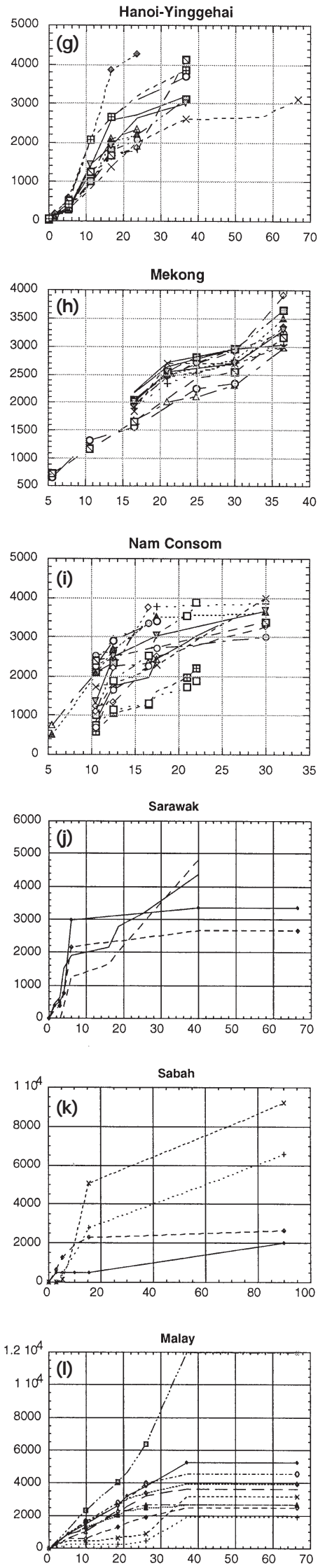
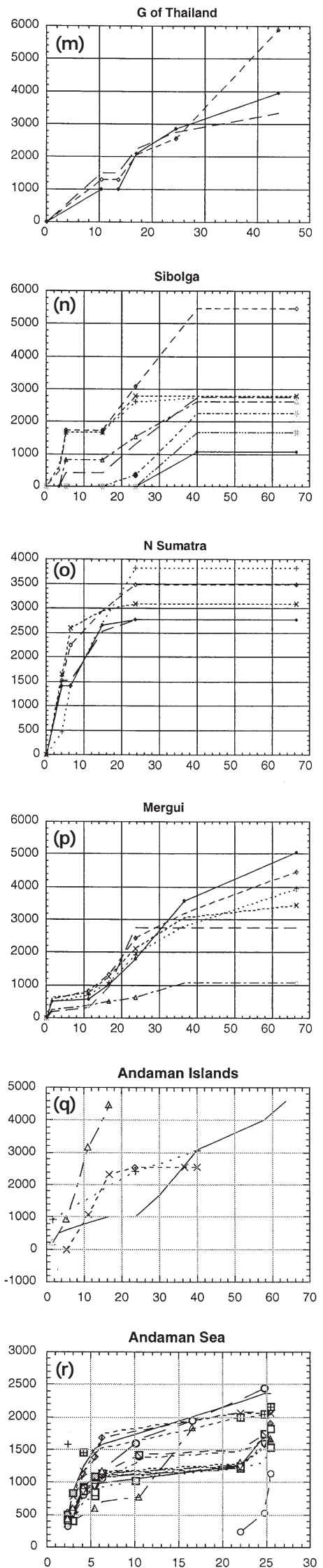

Figure 3. Cumulative thicknesses for several stratigraphic columns and geological sections of Asian basins. $x$-axis: ages in $10^{6}$ yr; $y$-axis: cumulative thickness in $\mathrm{m}$. Because most of the data come from petroleum company TOTAL CFP, exact correspondence with locations in Fig. 1 are not shown but can partly be obtained from the authors on request. Other sources are listed in text. 

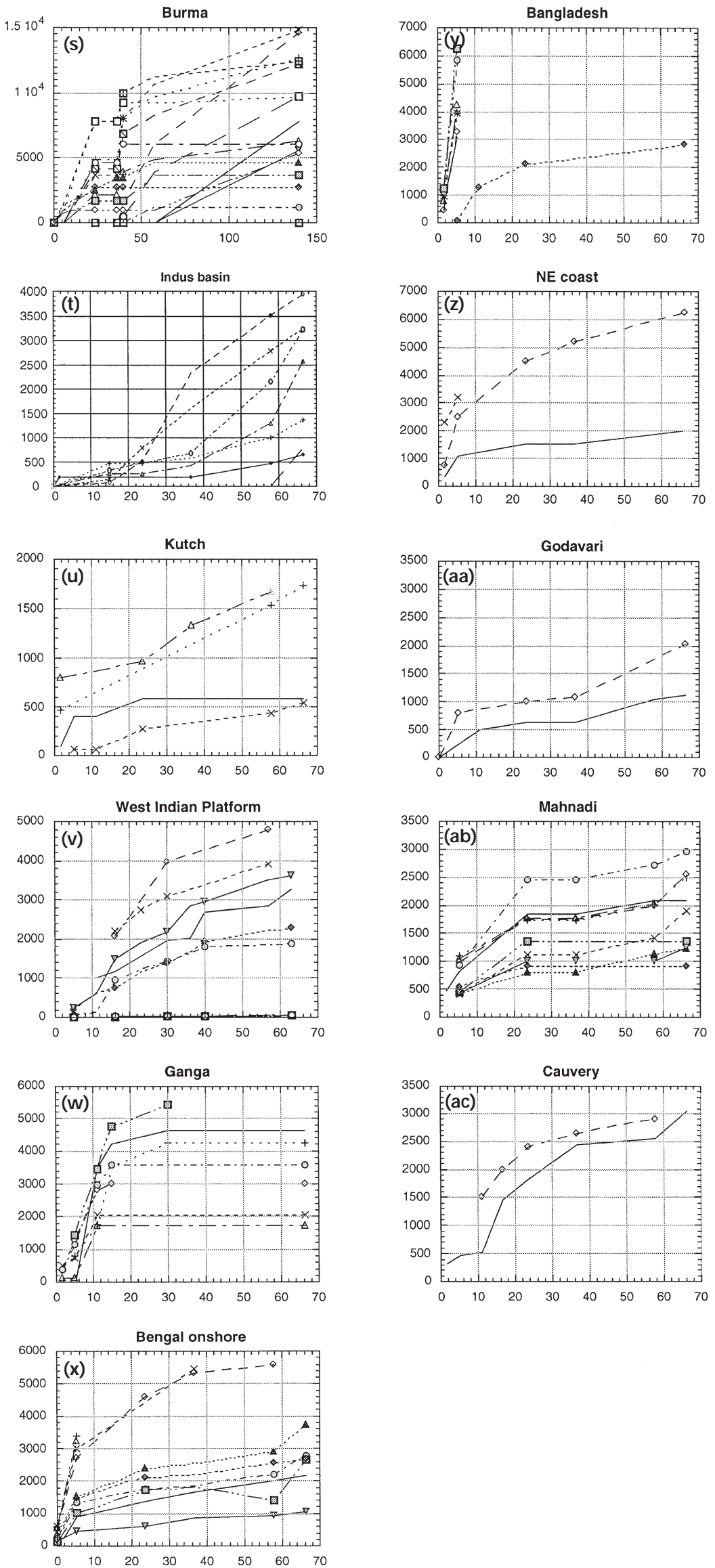

Figure 3. (Continued.)

(C) 1999 RAS, GJI 137, 280-318 
but the sedimentary history of the Okinawa basin extends back only through the Pliocene (CCOP 1991) or possibly into the Miocene (Zhou et al. 1989). Palaeogene sediments (up to $2000 \mathrm{~m}$ ) of the ECS basin are composed of three formations, the Linfeng, Oujiang and Pinghu, which comprise coastal and shallow-sea deposits (Zhou et al. 1989). Typical continental deposits, fluvial and lacustrine, started to accumulate during the Oligocene (Huangang formation). Alternating continental and marine strata accumulated during the Miocene (Longjing, Yuquan and Liulang formations). Since the beginning of the Pliocene, the deposits consist of alternating marine and continental sandstones and silts [Pliocene Santan and Quaternary Donghai formations (Zhou et al. 1989)]. DL Neogene thicknesses range between 1000 and $2500 \mathrm{~m}$.

Sedimentary units that accumulated to the south in the Taiwan basins are mainly shallow marine sediments. Lateral facies variations are numerous from the south to the north of the island; they are extensively described by Ho (1988). The oldest sediments are Oligocene and composed of calcareous sandstones and dark shales. The Miocene deposits rest unconformably on the Oligocene and consist of clastics, sandstones, siltstones and claystones. Pliocene deposits consist mainly of marine clastics. The sediments become finer and thicker to the south of the island. During the Quaternary, marine and continental sediments of all types accumulated west of the island

\subsubsection{The Pearl River Mouth basin}

Near Hongkong and Macao, at the mouth of the Pearl (Zhu) River, the sedimentary basin of the same name extends over a distance of $800 \mathrm{~km}$ along the Chinese coast north of Hainan Island (Figs 1 and 3d). Its structure is a series of parallel, elongated depressions formed by northwest-southeast extension along normal faults (Zhong 1985). The oldest sediments range from Palaeocene (Guong et al. 1989; CCOP 1991) to Oligocene (Zhong 1985). The first extension phase seems to have been Palaeocene and affected all of the main depressions of the basin. Until the end of the Oligocene (Zhujhai formation) the deposits were continental, fluvial and lacustrine. After the beginning of the Miocene (Zhujiang, Hanjiang and Yuehai formations) the depositional environment became marine; sediments are sandy clastics with conglomerates (see Zhong 1985 for a complete description). Sediment accumulations range between 1500 and $2500 \mathrm{~m}$.

\subsection{Basins surrounding Indochina}

\subsubsection{Hainan basins: Beibu, Song Hong-Yinggehai and Qongdongnan}

Three sedimentary basins surround Hainan Island in the Gulf of Tonkin northwest of the South China Sea: the Beibu basin, the Song Hong-Yinggehai basin, which continues inland into the Hanoi basin, and the Qongdongnan basin (Figs 1 and $3 \mathrm{e}-\mathrm{g}$ ). The structure of the Beibu and Qongdongnan basins is grabens and half-grabens separated by structural highs while that of the oval-shaped Yinggehai basin seems to be related to its position in the prolongation of the Red River strike-slip fault zone. The oldest sediments encountered in DLs of the Hanoi and Beibu basins, at $2700 \mathrm{~m}$ depth, are Palaeocene (Chengliu formation of Palaeocene to Eocene age) and consist of red sandstones and conglomerates deposited in an alluvial environment. The Liushagang lacustrine shales of middle Eocene to early Oligocene age rest unconformably on the older strata. They are overlain by the early Miocene Weizhou and Xiayang formations composed of claystones, sandstones and intercalated conglomerates. Sediments of middle Miocene age (Jiaowei formation) are finer and more calcareous in the Yinggehai and Qongdongnan basins. During the upper Miocene the sediments that accumulated in the Beibu Gulf region (Dengloujiao formation) become coarser than those in the Yinggehai basin (Huangliu formation). They are absent from the Qongdongnan basin where biostratigraphic correlations indicate a $7 \mathrm{Myr}$ hiatus in sedimentation at that time. Claystones and sandstones accumulated from the Pliocene to Recent (Wenglougang formation) in the three basins without any marked discontinuities in the sedimentation process (see Zhang \& Kou 1989 for a general review of the stratigraphy). The Neogene sequences range from 2000 to $4000 \mathrm{~m}$ in thickness and can even reach $5000 \mathrm{~m}$ in deep wells of the Qongdongnan basin (east of Yinggehai)

\subsubsection{Mekong and Nam Consom basins}

These two basins are aligned along the prolongation of the Mekong River offshore Vietnam (Figs 1 and $3 \mathrm{~h}$ and i). They are grabens that formed during the Cenozoic. The basal sequence is a sandstone-rich layer inferred to be of Oligocene age $(300-800 \mathrm{~m})$. During the Miocene the depositional system in the Mekong basin evolved into an open sea environment. To the south, in the Nam Consom basin, deposition took place in a fluvial and deltaic environment. Bedding progressively disappeared during the middle Miocene, especially in the Mekong basin; the sediment was clastic with a very high sand/ clay ratio. There seems to be a hiatus around 10.5 Ma. This marked discontinuity occurs throughout the Nam Consom basin. Pliocene and younger sediments are composed of 80 per cent or more of sands (Mekong basin and Nam Consom basin, TOTAL TEP DE 1990 unpublished reports). Neogene strata are up to $3500 \mathrm{~m}$ thick.

\subsubsection{The Sarawak and Sabah basins}

These two basins, of Tertiary age, are located north of the island of Borneo (Kalimantan); their deepest parts are located offshore (Figs 1 and $3 \mathrm{j}$ and $\mathrm{k}$ ).

Sarawak. The stratigraphy of the basin can be subdivided into several sedimentary cycles separated by short transgressive intervals (e.g ESCAP 1978; ASCOPE 1981; CCOP 1991; Hamilton 1979; Hutchinson 1989). Cycles I and II extend from the Eocene to the lower Miocene and have sediments that accumulated in a coastal environment laterally grading into marine beds. Cycle III is lower to middle Miocene and has argillaceous and carbonaceous facies. It is present in only twothirds of the basin. Cycle IV is middle Miocene and Cycle V is middle to upper Miocene; this was the time when reefs formed in the Luconia province $\left(\approx 112^{\circ} \mathrm{E}, 4^{\circ} \mathrm{N}\right)$. Cycles VI to VII are late Miocene to Quaternary and correspond to the deposition of clastic sandy materials over the entire area. 
Sabah. This basin is located to the northeast of the Sarawak basin along Kalimantan. It extends from the piedmont of the mountains formed by folding of the Cretaceous to Oligocene Crocker formation in the east to the Sabah trough in the west. The latter is inferred to have been active throughout the Early Tertiary from the Palaeocene to the lower Miocene. Clastic material rests on the Crocker formation. The lower Miocene sediments are mainly clays and sandy turbidites (Setap and Meligan formations). During the rest of the Miocene (Belait formation) and afterwards, sediments accumulated in shallow marine and coastal environments (e.g. ESCAP 1978).

\subsubsection{The Malay basin}

The Malay basin extends from the Gulf of Thailand to the South China Sea (Figs 1 and 31). Its elongate oval form is similar to the Yinggehai basin described above (Fig. 1). The long axes of these two ellipsoidal depressions separated by the Indochina peninsula are subparallel. The opening mechanism of such basins is unclear. The age of the basal deposits in the deepest part of the basin is not known. Tapponnier et al. (1986), Briais et al. (1993) and Lacassin et al. (1996) suggested that the opening of these two structures was related to strike-slip faulting along large structures such as the Wang Chao and the Three Pagoda fault zones. Folding in the deepest parts of the basin is interpreted to reflect the presence of strike-slip faults or of a shear zone at depth (ASCOPE 1981). The stratigraphy has been described in terms of deposition cycles. The description of each of these cycles, as in the case of the Sarawak and Sabah basins, relies on sequence stratigraphy and on palynological and planktonic analysis. The basement is formed by Cretaceous or older igneous rocks. The base of Cycle I, corresponding to red fluviatile sandstones, is assigned to the Oligocene. It is separated from the overlying Cycle II (Lower to middle Miocene) by a hiatus. The latter cycle is composed of successive sequences of fluvio-lacustrine, littoral and deltaic or swamp deposits. Cycle III (Late Miocene to Recent) is composed of littoral sandy sediments, more or less coarse, with some shale pebbles and intercalated limestones (e.g. ASCOPE 1981; Hutchinson 1989).

\subsubsection{The Gulf of Thailand}

At the northern limb of the Gulf, south of the mouth of the Chao Phraya, different north-south-trending grabens have been the site of ongoing sedimentation since the early Tertiary (Figs 1 and $3 \mathrm{~m}$ ). This region, known as the Thai basin, is composed of a series of almost parallel sub-basins. From west to east these are the Chumphon, the West, the Kra and the Pattani (the deepest) depressions. Sedimentary units are identical to those found in the Western Malay basin. The three-cycle classification is similar, but the boundary between the second and third cycles, at 1200-1800 m depth, has been dated with some accuracy by radiometric ages of intercalated basaltic flows and dating of fossil mammals. The ages range from 13.6 to $10.4 \mathrm{Ma}$ (Pradidtan \& Dook 1992). The oldest sediments are assigned to the Oligocene (700-2400 m), although the regional subsidence of the depressions is thought to have begun at the onset of the Tertiary (ASCOPE 1981). The upper Miocene to recent sediments are $\approx 1000-1500$ m thick.

\subsubsection{The basins of Sumatra}

The Sibolga basin lies west of the Island of Sumatra and east of the subduction zone. It constitutes the main forearc basin of the island and is filled with Tertiary sediments (Figs 1 and 3n). The age of the oldest deposits is the subject of ongoing arguments: Miocene (Hutchinson 1989) or Late Eocene (Oyo formation) (CCOP 1991). Until the lower Miocene (Nias formation) the sediments were clastics, mainly sandstones. During the middle and upper Miocene platform carbonates accumulated in the Sibolga basin. The Pliocene is composed of sandstones (Nalawo formation) and limestones (Sitoli formation) (Hutchinson 1989; CCOP 1991).

On the eastern side of the island, several back-arc basins can be distinguished: the north (Fig. 3o), central and south Sumatra basins. The northern basin merges to the north with the Mergui basin and the Andaman Sea. The two other basins are mostly onshore. As in the case of the Sibolga basin there seems to be no general agreement as to the age of the different formations that accumulated in the basins. To the north, sedimentation began in the upper Eocene-lower Oligocene with the Parapat series. The depositional environment was fluviatile and became marine coastal with the accumulation of the Bampo formation [CCOP (1991) assigned an Oligocene age to the two formations, while Hutchinson (1989) assigned an Oligocene to Lower Miocene age to the latter formation]. Marine sedimentation continued with the accumulation of the Arun and Belumai limestones and claystones. The middle Miocene is composed of the Baong shales. The upper Miocene (Keutapang) and the Pliocene (Seurula and Jurulayeu) are coastal clastic deposits.

In the centre of the island the oldest deposits are Palaeocene. The Permatang formation, which consists of carbonaceous claystones, accumulated until the lower Miocene. The lower to middle Miocene sediments are shales and limestones (Telisa formation). Grey shale and sand beds attest to successive regression phases since the middle Miocene (Petani formation). The depositional environment progressively became continental (Hutchinson 1989).

To the south, deposition began with the Kikim sandy tuffs and conglomerates of Late Cretaceous age. From the Palaeocene to the Oligocene (Lemat formation) the sediments were sandstones, sands and tuffs followed by brackish clays and sandstones. From the Oligocene to the Early Miocene, sandstones, silts and clays were deposited in a deltaic environment. They are capped by the Telisa formation described above. The overlying Palembang formation consists of shallow marine sedimentary units. The Plio-Pleistocene sediments are deltaic sands and gravels (Hutchinson 1989).

\subsubsection{The Mergui basin}

At the boundary between the straits of Malacca and the Andaman Sea, the Mergui basin (Figs 1 and $3 p$ ) extends from the Megui High to the west, to the southern tip of the Tenasserim Mountains to the north and connects with the north Sumatra basin to the south. It is a series of roughly north-south-trending half-grabens. Extension and coeval onset of sedimentation began in the Oligocene (CCOP 1991). The deposits are fluviatile or shallow marine sandstones and shales (Ranong formation). The lower Miocene (Tai formation) corresponds to a deepening of the depositional 
environment. The sediments are shales and limestones. Since the middle Miocene (middle Miocene Trang formation, upper Miocene Thalang formation and Plio-Quaternary Takua Pa formation) the sediments have been essentially turbidites (CCOP 1991).

\subsubsection{The Andaman Islands and Sea}

Onshore, the stratigraphy of the Andaman and Nicobar Islands can be summarized as follows (see Fig. $3 \mathrm{q}$ for cumulative thickness curves): the oldest formation is the Cretaceous Port Meadow radiolarites, quartzites and limestones (metamorphosed into marble), which accumulated in a deep marine environment. It is followed by the Cretaceous to Late Eocene Baratang and the Oligocene Port Blair formations, composed of sandstones, shales or silts, overlying basal conglomerates. Palaeogene strata are up to $3500 \mathrm{~m}$ thick in drill holes east of the Archipelago. From the Miocene to the Pliocene, the Archipelago group accumulated. It may be subdivided into the microsandstones and claystones of the Round formation (middle to upper Miocene) followed by the foraminiferal limestones of the Guitar formation (Pliocene) and clays and silts of the Long formation (Pliocene). Recent deposits accumulated in alluvial, tidal or reef environments.

Offshore (Fig. 3r), the oldest formation drilled is the Baratang. The Port Blair, Round and Long formations are separated from the overlying series by discontinuities (Andaman Nicobar Basin, TOTAL TEP DE, unpublished report). Neogene and Quaternary sediment accumulations range from $700-2500 \mathrm{~m}$ in offshore DLs.

\subsubsection{Basins of Burma (Myanmar)}

Cenozoic continental basins of Myanmar extend over an arched area corresponding to the Chindwin-Irrawady river's alluvial plains. They are limited to the west by the Tertiary Naga, Chin Yoma and Arakan mountains forming the IndoBurman ranges. To the east, the right-lateral Sagain fault, following the Shan Scarp, marks the boundary with the highlands of the Shan and Tenasserim plateau. Depressions are aligned along the curved line formed by the eastern piedmont of the Indo-Burman ranges. From north to south the basins are known as the Chindwin, Minbu, Pegu-Yoma and Irrawaddy delta basins. The oldest sediments encountered are Orbitolinabearing limestones in the jade mines of the Chindwin basin (e.g. ESCAP 1978). Detrital sedimentation occurred in all the depressions during the Upper Cretaceous as the Kabaw formation The sediments are sandstones and marine claystones with few limestones. The Tertiary sediments are essentially molasse deposits [Fig. 3(s) shows some cumulative thicknesses obtained from geological sections, while Fig. 3(r) shows cumulative thickness curves in the Andaman Sea, some from DLs offshore of the Irrawaddy mouth]. During the Palaeocene and Eocene both arenaceous formations (Paunggyi, Tilin and Pondaung) and clay-rich formations (Laungshe, Tabyin and Yau) were deposited. The Oligocene deposits are thin, with the main depocentres in the Minbu depression. Geological sections show thicknesses of up to $12 \mathrm{~km}$ of Cretaceous to Palaeogene sediments. Neogene strata rest unconformably on the older units. To the north, in the Chindwin depressions, freshwater deposits accumulated (Letkat, Natma and Shwethamin). To the south sediments accumulated in a shallow marine environment (Tumyaung, Kwingyaung and Kathabaung). They are overlain by the upper Miocene and Pliocene Irrawaddy formation and by Recent alluvium (e.g. ESCAP 1978).

\subsection{Basins of the Indian Plate}

\subsubsection{The Indus fan and basin}

The Indus basin extends over $1200 \mathrm{~km}$ from north to south at the western border of the Indian subcontinent in Pakistan (Fig. 1). It is bounded to the west by the Kirthar and Sulaiman ranges and to the north by the Potwar Plateau and the Main Boundary Thrust. In Punjab, the Indus River and four tributaries, the Sutlej, the Ravi, the Chenab and the Jhelum Rivers, flow from the summits of the Himalaya, Karakorum and Indukush. The basin is subdivided into two geographic units: the Higher and Lesser Indus, the latter being divided into northern, central and southern parts (Bender \& Raza 1995 pp. 28-31). Three depocentres have been described: Kirthar, Sulaiman and Potwar. The first two lie in the lesser Indus basin while the third represents the Higher Indus basin. Cenozoic deposits can be roughly divided into two separate depositional environments: Palaeogene (900-3400 m) marine and Neogene $(<800 \mathrm{~m}$ in DLs) continental clastic sediments. These two distinct sedimentation patterns are separated by thin accumulations, sometimes hiatuses, during the Oligocene (Fig. 3t). As is the case for the Bengal fan and the Taiwan basins, formations and units are numerous. We shall name only the principal units (see e.g. Bender \& Raza 1995 for an extensive stratigraphy of the basin). At the front of the Kirthar ranges, Palaeocene sediments belong to the Ranikot group. From bottom to top the deposits are marine sediments (Khadro formation) evolving to fluviatile sandstones and claystones (Bara formation) and capped by marine limestones and coastal sandstones (Lakhra formation). To the north at the front of the Sulaiman ranges, the Palaeocene consists of fossiliferous limestones of the Dungan formation, while in Potwar sediments of the Makarwal group evolve from continental sandstones (Hangu formation) to marine limestones (Lockhart formation) and marine sandy and calcareous claystones (Patala formation). Fig. 3(t) shows cumulative thickness curves sampled throughout the basin.

During the early Eocene, sedimentation was uniform in the Kirthar and Sulaiman depocentres. The Gazij group consists mainly of fossiliferous marine claystones with various intercalations. This group is overlain by limestone-rich (the Kirthar, the Habib Rahi and the Pirkoh) or claystone-rich (Domanda) formations of middle Eocene to Oligocene age. In the Higher Indus, successive stratigraphic units of the Eocene consist of the Panoba claystones, saline Bahadur Khel formation, Shekhan massive limestones and gypsum series, gypsum-rich or arenaceous clays of the Kuldana formation and finally the thick nodular limestones of Kohat. All these Eocene formations are overlain by Neogene sediments.

The Oligocene to lower Miocene Nari formation [36-20 Ma according to Latif (1964) and cited in Bender \& Raza (1995)] is present in the Lesser Indus basin. This deposit evolves from sandy limestones, carbonaceous sandstones and clays to coarse-grained sandstones and conglomerates.

In the Lesser Indus basin, Neogene sedimentation begins with the Early Miocene Gaj clays with intercalated sandstones and limestones. These are overlain by the Siwaliks, a 
description of which is given in the section on the Ganga Basin. To the north, in the Potwar depocentre, the Murree formation lies directly on Eocene sediments. The overlying Quaternary sediments are mainly composed of Pleistocene and Holocene alluvium that accumulated in the Indus plain.

In the deep-sea fan, the sediments that have been recovered are mainly composed of nannofossil-bearing chalk and ooze. Unconformities are encountered during the Eocene and at the Eocene-Oligocene boundary. Neogene and Quaternary sedimentation seems to have been continuous.

\subsubsection{The Kutch basin}

Offshore, Tertiary sediments directly overlie the Deccan Traps or, to the west, the older Bhuj formation Palaeocene sediments (Matanomadh formation) are composed of silts and dark shales. From the Eocene to the Oligocene (Naredi-Hrudi Fulra and Maniyara Fort formations, 200-700 m thick) the sediments are mainly limestones. Since the beginning of the Miocene (Khari Nadi and Vinjhan shale) the sediments consist of alternating accumulations of clays, silts and sands with a total thickness of the order of 500-950 m (Kutch basin, TOTAL TEP DE, unpublished report, Fig. 3u).

\subsubsection{The Western Platform}

Sediments that accumulated on this platform along the west coast of India originate from the eastern Ghats and the onshore part of the Deccan Traps. The erosion products were carried by the Narmada River, although most of the yield of the river accumulated in the Bombay basin. Tertiary sediments lie on the traps. The Palaeocene deposits are sandstones and claystones. During the Eocene, Oligocene and Miocene sediments deposited were mainly carbonates, evolving to a more shaly facies towards the Indus fan. From the middle Miocene onwards, shales accumulated throughout the basin (e.g. Mohan 1985 and Fig. 3v)

\subsubsection{The Ganga basin}

Deep wells and magnetostratigraphic cross-sections give some insight into the stratigraphy of the Ganga basin (Figs 1 and 3w) (Sastri et al. 1971; Acharyya \& Ray 1982; Johnson et al. 1983; Burbank \& Reynolds 1984). Above the Proterozoic Vindhyan basement, an intermediate sequence of ferruginous red beds and laterites remains undated. These strata are not present throughout the basin and are overlain successively by the Subathu and Dharamsala formations (up to $2500 \mathrm{~m}$ thick). The former is composed of nummulitic limestones and carbonaceous shales, while the latter is composed of clay sandstones and shales. These two sedimentary units are not found everywhere in the basin. The Dharamsala formation constitutes an equivalent of the Murree described to the west in the Potwar and Punjab regions, as indicated by their relative positions, which are similar to the Subathu and Siwalik formations. To the west the boundary between the Murree and the Siwalik is not always clear.

The alluvial and fluvial molassic Siwalik deposits are subdivided into the lower (900-1800 m), the middle (1000-2000 m) and the upper (200-900 m) Siwalik series. This subdivision is used throughout the Himalayan piedmont [see Ganser (1964) and Delcaillau (1992) for a complete description of the series].
The age of the Siwalik sediments has been the subject of much research for over 30 years. The results seem to indicate an age of Early Miocene to Pleistocene for the entire series (Delcaillau 1992). The sub-sequence boundaries correspond to isochrons, as pointed out by Ganser (1964). Very roughly one may summarize the stratigraphy as follows. The lower Siwalik consists of sandstones and clays with local conglomeratic accumulations; it is subdivided, from base to top, into the Kamlial and Chinji formations, the former being mainly composed of sandstones, while the latter is composed of red clays and silts. The middle Siwalik sequence is also divided into two formations, the Nagri and Dhok Patan. The first is composed of thick sandstones with intercalated claystones, while the second is mainly formed of claystones and silts with interbedded fine-grained sandstones. The upper Siwalik is divided into three formations: Tatrot, Pinjor and the Boulder conglomerate. The deposits are coarse, with many conglomerates and breccias. The Siwalik series is overlain by the recent alluvium of the Ganges River (Fig. 3w).

\subsubsection{The Bengal Fan}

The Ganges-Brahmaputra delta. The Neogene series of the Bengal fan are characterized by a monotonous succession of sandstones, silts and clays bearing no datable fossils. They overlie the Sylhet limestone and the unconsolidated Tura sandstones, both of Eocene age. The oldest sediments drilled in Bangladesh in the deepest part of the basin have been assigned a late Miocene age. They could belong to the Tipam sandstone formation (Maroof Khan 1980). The delta is bounded to the east by the Indo-Burman ranges. To the west the depth of the basin diminishes towards the Ganga basin. The maximum thickness of the sediment is assumed to be between 17 and 21 km [Fig. 1; Curray $(1991,1994)$ proposed an upper estimate of $22 \mathrm{~km}$ suggesting metamorphosed rocks of greenschist facies at the base]. Seismic analyses seem to indicate a history that began with the accumulation of the Sylhet limestones. The sedimentation above this reference horizon may roughly be described as follows: from bottom to top are the Barail (Oligocene) and Surma (Miocene) groups, the Tipam (Mio-Pliocene) formation, and the Dupi-tila (Plio-Pleistocene) group. The depositional environment was deltaic. A noticeable feature of sedimentation is the decrease in grain size with increasing depth of the environment. Also, the clay proportion increases towards the southwest and, conversely, the sand proportion increases towards the northeast. These observations are in good agreement with the growth of a delta from the northeast towards the southwest. The Tipam formation disconformably overlies the older units. It contains fluvial deposits, consisting of arenaceous, coarse-grained sandstones and conglomerates. The presence of shale pebbles indicates incorporation of older sediments through episodes of violent erosion (major floods, for example). The Dupi-Tila group is composed of coarse-grained Fe-rich sandstones and claystones. The grain size decreases towards the upper part of the sedimentary sequence. The presence of wood remains and lignite indicates a deltaic depositional environment (e.g. Khan et al. 1988; Alam 1989; Reimann 1993).

In the West Bengal Basin in India, drilling has penetrated the oldest sedimentary formations and reached the Archaean basement of the basin. The Palaeocene Jalangi formation is composed of claystones and thin limestone beds. 
The depositional environment was brackish and marshy. Eocene sediments are similar. Oligocene sedimentation is characterized by the Burdwan, Diamond Harbour and Memari formations, which are mainly composed of claystones that accumulated in shallow marine environments. Palaeogene sequences are 500-1800 m thick in DLs. During the Miocene (Pandua and Matla formations) and the Pliocene (Debragam and Ranaghat formations) the sediments deposited were mainly claystones, with some silt and sands deposited under brackish and deltaic environments (Bengal basin, TOTAL TEP DE, unpublished report). Neogene and Quaternary thicknesses in the basin range from $600-4600 \mathrm{~m}$. The Miocene deposits are separated from the underlying series by a discontinuity, dated at 10.5 Ma (Lindsay et al. 1991). Lindsay et al. (1991) found a very thin sequence that accumulated between 21 and 10.5 Ma. Figs 3(x) and (y) show the different cumulative thickness curves obtained from drilling in the basin in India as well as in Bangladesh.

The Northeast Coast. Southwest of the mouth of the GangesBrahmaputra, the coast of India is also known as the Northeast coast (Fig. 1) and is part of the Ganges-Brahmaputra fan complex. In this area the Precambrian basement is covered by clay, shales and limestones of early Cretaceous age. Palaeocene and Eocene shales, silts and limestones lie unconformably on these units. The accumulations may reach $1000 \mathrm{~m}$ in thickness. They are unconformably overlain by the Miocene and Pliocene series composed of claystones and silts. During the Pleistocene, sedimentation coarsened and sandstones accumulated (Fig. 3z; TOTAL TEP DE, unpublished report). From the Miocene to Recent, $4500 \mathrm{~m}$ of sediments accumulated on the platform.

The Eastern Platform of India. $100 \mathrm{~km}$ south of the Bay of Bengal, the Mahnadi delta and its prolongation seawards on the platform provide some information about the stratigraphy of the fan (Figs 1 and 3aa). The deposits become thicker towards the fan, with which they merge in apparent continuity. Palaeocene deposits consist of mudstones, shales and sandstones deposited in a deltaic or shallow marine environment. During the Eocene, fossiliferous limestones and shales or sandstones accumulated in a platform environment. Oligocene deposits are absent. Miocene and younger deposits lie unconformably on older strata and are composed of silt, clays and sandstones. Induration of the sediment decreases from bottom to top.

To the south just, before the Indian coast crosses the $80^{\circ} \mathrm{E}$ meridian, the Krishna and the Godavari Rivers form two deltas that join together and discharge their yield onto the platform and into the Bay of Bengal (Figs 1 and 3ab). The oldest sediments on the platform and in the fan are Cretaceous. Accumulation took place in a platform environment and prograded seawards. The sediments are shales and claystones with some sandstones. During the Eocene, massive limestones also accumulated. From the Miocene onwards, the sediments were more sandy. The depositional environment was shallow marine (Krishna-Godavari Basin, TOTAL TEP DE, unpublished report).

Further to the south, at the mouth of the Cauvery River (Figs 1 and $3 \mathrm{ac}$ ), several sedimentary basins are aligned along NE-SW-trending normal faults. The infill of these grabens is Mesozoic, whilst the Cenozoic sedimentation unconformably overlies the older deposits and hides the grabens. As along the rest of the coast, accumulation prograded seawards and merged with sedimentation in the Bengal fan. Accumulation took place in shallow (platform) and deeper marine environments. From the Palaeocene to the Oligocene the sediments were limestones, shales and sandstones. During the Oligocene and until the late Miocene, the sedimentation was dominated by shales. Since the middle Miocene clays and more or less coarse sands have accumulated on the margin.

The distal part of the fan. In the distal part of the Bengal Fan, about $800 \mathrm{~km}$ from Ceylon, three holes (717, 718 and 719; e.g. Cochran et al. 1989) were drilled at about $1^{\circ} \mathrm{S}$ and $81^{\circ} 24^{\prime} \mathrm{E}$ during ODP leg 116. The stratigraphy described in this part of the fan, $2000 \mathrm{~km}$ away from the mouth of the Jamuna river, extends back into the Miocene (17 Ma). The sediments are turbidites. Five units have been described. Unit I, a few metres thick, corresponds to Holocene deposits. It is composed of very fine clays and mud turbidites. Unit II corresponds to Pleistocene deposits and is mainly composed of silts. Units III and IV are fine-grained mud turbidites that accumulated during the late Miocene and the Pliocene. Unit $\mathrm{V}$ is very thick and corresponds to monotonous accumulations of grey turbidites with mud and silt (Cochran et al., 1989; Cochran 1990).

\section{DATA ANALYSIS}

In the following paragraphs we briefly summarize the technique developed by Métivier \& Gaudemer (1997) to estimate the masses accumulated in a sedimentary basin. Calculating mass from sediment thickness measurements implies a knowledge of how density varies with depth. There are two ways of making such a calculation if the stratigraphic sequence is known: $\left\{\left(z_{i}, t_{i}\right), i=1 \ldots N\right\}$, where each $\left(z_{i}, t_{i}\right)$ pair defines the age $\left(t_{i}\right)$ and the depth $\left(z_{i}\right)$ of the $i$ th stratum (the first being the youngest) and one of the following quantities: density $\rho(z)$ or porosity $\omega(z)$. Given depth and density, the mass accumulation $M$ per unit area over a time interval $\Delta t$ is

$M(\Delta t)=\int_{z_{1}}^{z_{2}} \rho(z) d z$

where $z_{1}$ and $z_{2}$ are the upper and lower limits of the strata deposited during the time interval $\Delta t=t_{2}-t_{1}$. This is the most precise way to obtain $M(\Delta t)$. Knowledge of $\rho(z)$ often being poor, one can derive the mass from a knowledge of the porosity.

From depth and porosity, one can obtain the grain volume (Gallagher 1989), which can be directly related to the mass by the grain density $\rho_{\mathrm{g}}(z)$ :

$M(\Delta t)=\int_{z_{1}}^{z_{2}} \rho_{\mathrm{g}}(z)[1-\omega(z)] d z$

The grain density is often considered to be constant, $\bar{\rho}$, as shown in Fig. 4(a), where density measurements from ODP sites 717, 718 and 719 (Cochran et al. 1989) show that for the sediments of the Bengal fan

$\bar{\rho} \approx 2.78 \pm 0.14 \times 10^{3} \mathrm{~kg} \mathrm{~m}^{-3}(2 \sigma)$.

This is very close to the well-accepted average value of $2.7 \times 10^{3} \mathrm{~kg} \mathrm{~m}^{-3}$ (Baldwin \& Butler 1985; Curray 1994) and the value of $2.75 \times 10^{3} \mathrm{~kg} \mathrm{~m}^{-3}$ usually assumed for the density of crustal rocks. However, it should be noted that in a marine sedimentary environment, low values of $\bar{\rho}$ can arise owing 


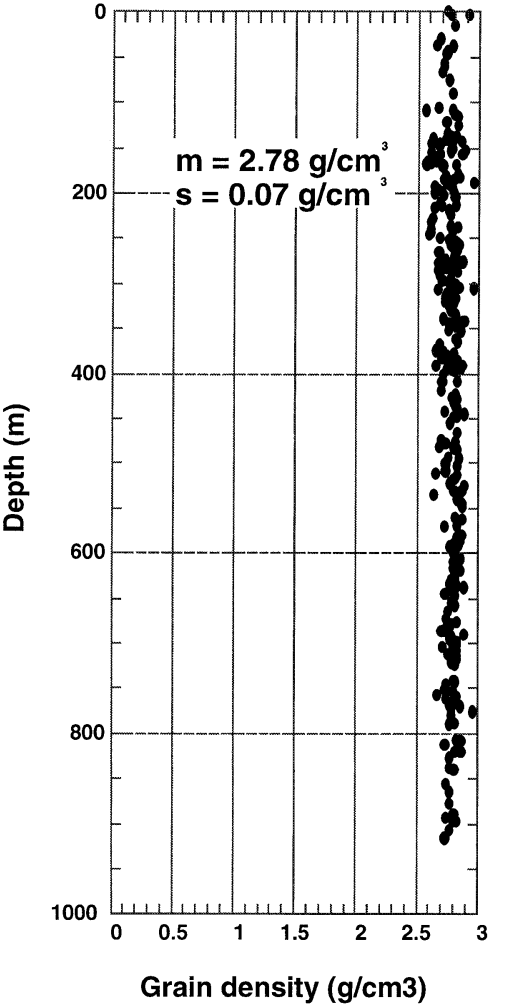

(a)

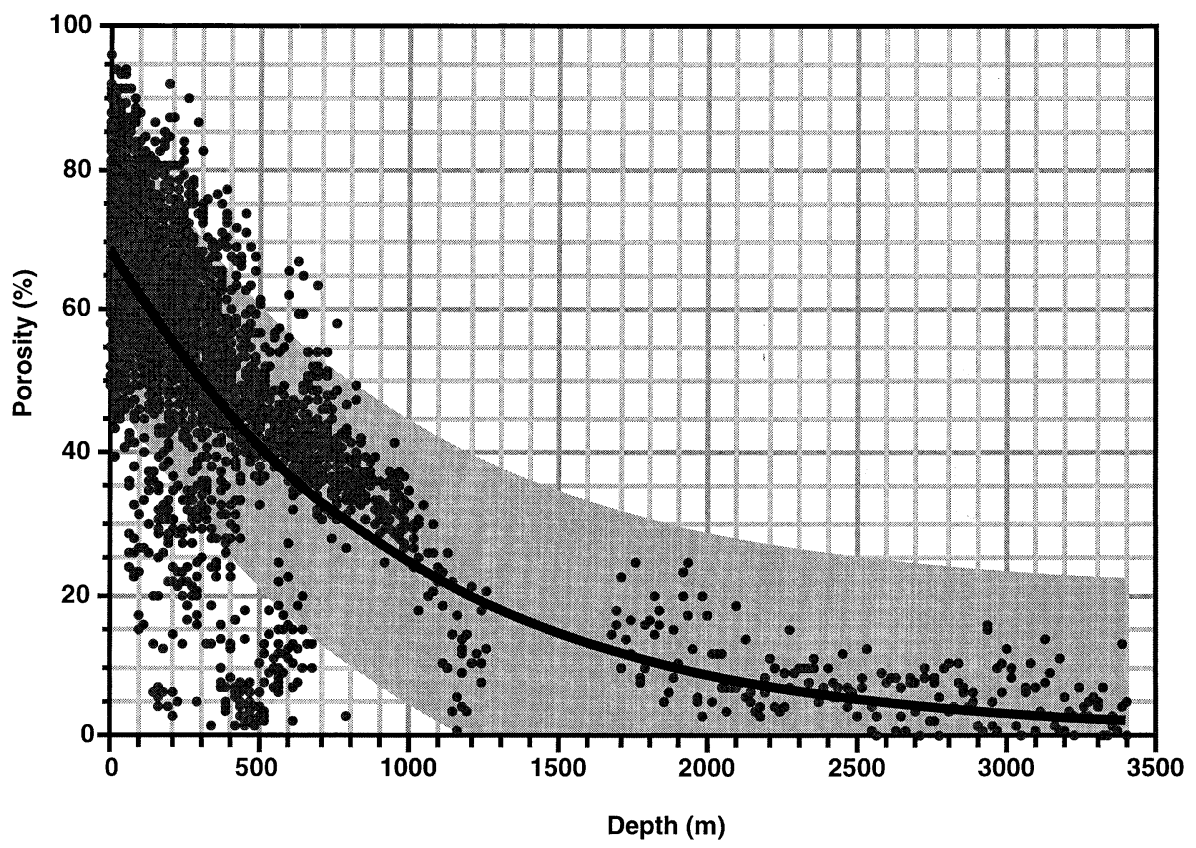

(b)

Figure 4. (a) Grain density measurements in several ODP DLs showing the remarkable consistency of $\rho$ averaging, $\rho_{\mathrm{g}}=2.78 \pm 0.14(2 \sigma) \mathrm{g} \mathrm{cm}^{-3}$. (b) Porosity data from different drill sites of Asia (ODP and courtesy of TOTAL CFP). Black curves correspond to fitting of data with an exponential curve of the form $\omega(z)=68.245 \exp (-z / 980)$ used to account for compaction of sediments. Grey-shaded area corresponds to the arbitrary uncertainty of 20 per cent assumed in order to ensure robustness of results.

to the presence of biogenic silica or siliceous ooze in the sedimentary column (Davies et al. 1995). We used values of porosity derived from ODP and DSDP drill holes in the Indian Ocean and values given to us by TOTAL CFP from its database on east Asia. These data were then fitted assuming an exponential decay of porosity with depth. This led to an average porosity of the form

$\omega(z)=68.245 \exp \left(-\frac{z}{980}\right)$.

The data and the resulting fitted curve are shown in Fig. 4(b), together with the uncertainty envelope of 20 per cent that we assumed in order to ensure robustness of our estimates.

\subsection{Mass accumulation}

The composite map that we made and used in this study shows the thicknesses that accumulated over a long time interval $(\approx 66 \mathrm{Myr})$. In order to obtain a detailed estimate of mass transfers through time, it is necessary to refine the sedimentary record with respect to time. This can be done with the detailed stratigraphic columns provided by drill holes. For example, if we want to analyse deposition in a given basin during the Tertiary we first determine the average thickness of the Tertiary, $H(x)$, for the entire basin by interpolation of local thicknesses of the Tertiary given by isopachs and drill-hole measurements. Next, we assume that only one drill hole is available. Measurements at point $x_{\mathrm{o}}$ indicate that the thicknesses of the $N$ layers accumulated during the Neogene are $h_{i}\left(x_{\mathrm{o}}\right), i=1 \ldots N$, with

$\sum_{i=1}^{N} h_{i}\left(x_{\mathrm{o}}\right)=H\left(x_{\mathrm{o}}\right)$,

where $H\left(x_{\mathrm{o}}\right)$ is the total thickness of the Neogene at location $x_{\mathrm{o}}$. Introducing the ratios

$R_{i}=\frac{h_{i}\left(x_{\mathrm{o}}\right)}{H\left(x_{\mathrm{o}}\right)} \quad$ for $i=1 \ldots N$,

we assume that, at any location $x$ in the basin,

$h_{i}(x)=R_{i} H(x)$ for $i=1 \ldots N$.

This implies that relative thicknesses are uniform over the entire basin (Fig. 5a). If $M$ drill-hole measurements are available, we divide the basin into $M$ domains, according to a criterion of minimum distance to drill-hole sites. As before,

$h_{i j}(x)=R_{i j} H(x)$ for $i=1 \ldots N$ and $j=1 \ldots M$,

where $H(x)$ is again the total thickness of the Neogene, $R_{i j}$ are the relative thicknesses of the $i=1 \ldots N$ layers measured in drill-holes $j=1 \ldots M$ (Fig. 5b), and $h_{i j}(x)$ is the thickness of the $i$ th layer at the point $x$ whose nearest drill site is $j$. Sharp discontinuities at boundaries of adjacent domains are smoothed out to ensure continuity of thickness (Fig. 5c). Given an average grain density, it is now possible to calculate the mass per unit area at each node of the grid that covers the basin, and then, by integration over the basin area, the mass deposited in the entire basin. 

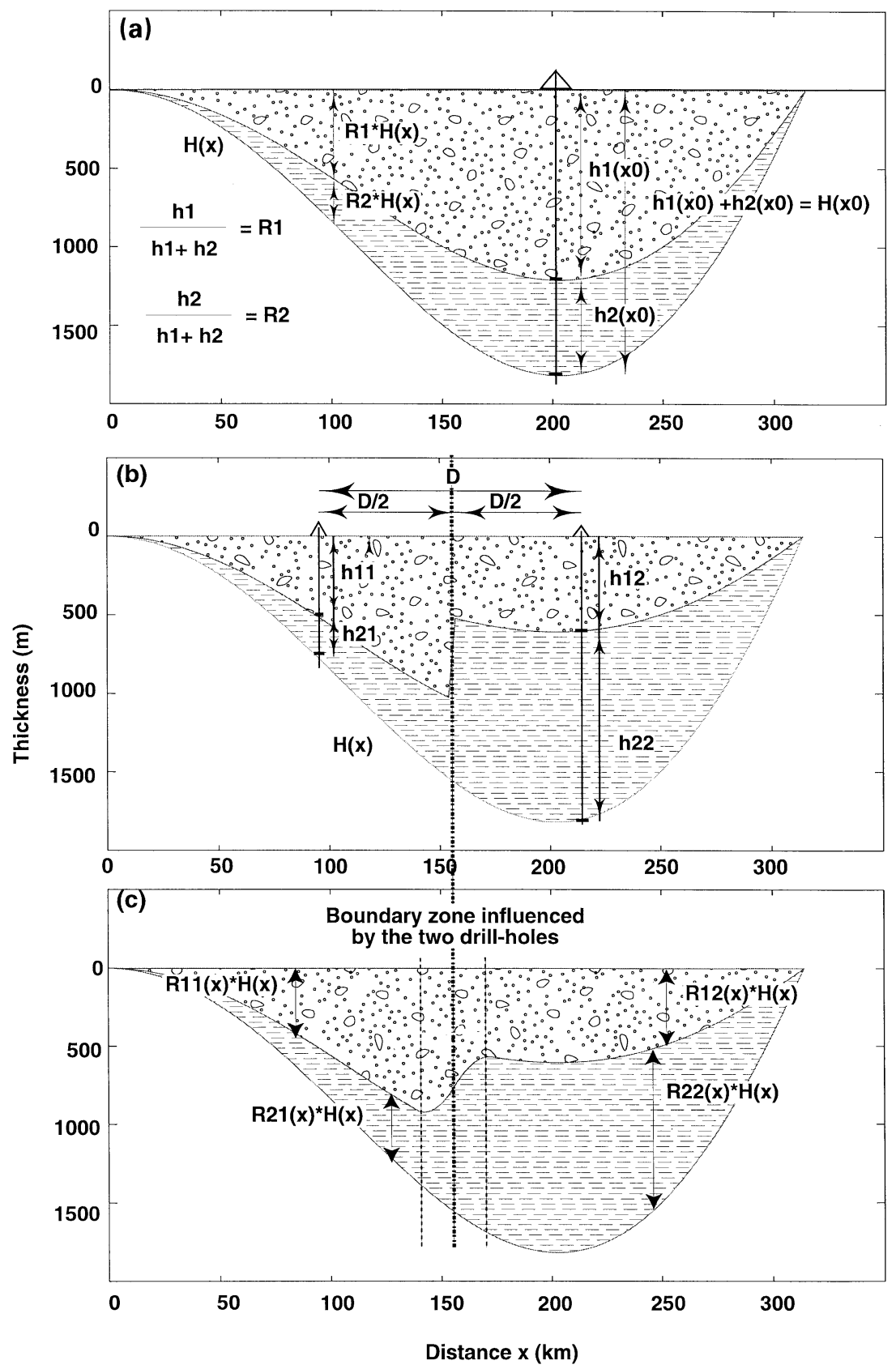

Figure 5. (a) 2-D reconstruction of two sedimentary layers from one isopach and one drill-hole. (b), (c) Same as in (a) for one isopach and two drill-holes, with smoothing of transition zone. Variables are defined in the text (from Métivier \& Gaudemer 1997).

From the preceeding calculation it is straightforward to generalize the results for a 2-D problem. We get

$\sum_{i=1}^{N} h_{i}\left(x_{\mathrm{o}}, y_{\mathrm{o}}\right)=H\left(x_{\mathrm{o}}, y_{\mathrm{o}}\right)$,

$R_{i}=\frac{h_{i}\left(x_{\mathrm{o}}, y_{\mathrm{o}}\right)}{H\left(x_{\mathrm{o}}, y_{\mathrm{o}}\right)} \quad$ for $i=1 \ldots N$,

$h_{i}(x, y)=R_{i} H(x, y)$ for $i=1 \ldots N$,

$h_{i j}(x, y)=R_{i j} H(x, y)$ for $i=1 \ldots N$ and $j=1 \ldots M$.

Eq. (12) gives the general formula for the reconstruction of $N$ different stratigraphic layers, provided the following are known: (1) the cumulative thickness of these layers everywhere in the depositional area; and (2) the exact stratigraphy at $M$ different points. The cumulative thickness is given by isopach data digitized and interpolated on a regular grid. Thus the maximum resolution of the reconstruction is given by the grid spacing. If we have one DL at each grid point the problem is completely determined. Details of the uncertainties in the calculations are discussed in Métivier \& Gaudemer (1997). We present here the formula for the uncertainty of the estimated thicknesses:

$\delta h_{\mathrm{g}, i}=\left|\delta h_{i} S\left(z_{i}\right)+\sum_{1}^{i-1} \delta h_{1}\left[S\left(z_{i}+h_{i}\right)-S\left(z_{i}\right)\right]+0.2 \int_{z_{i}}^{z_{i}+h_{i}} S(u) d u\right|$, 
where, at any point $(x, y)$ in a basin and for a stratum referenced $i, h_{\mathrm{g}, i}$ is the grain thickness, $S$ is the solidity $(1-\omega)$, $z$ is the depth of the base of the stratum and $h i$ is the thickness of that stratum

\subsection{Dating of clastic continental strata, data scatter and significance of the accumulation rates}

Our reconstruction results in a series of volumes that accumulated in each basin during each time period. Dating of continental strata in these basins is mainly based on palynology of cores recovered during drilling. In several places nannofossils and other biostratigraphic markers give reliable time estimates. However, because of the general lack of fossils and of reliable and datable markers, the stratigraphy of the basins of Asia is mainly linked to palynological analyses and seismic stratigraphy. There is no way to quantify the uncertainty associated with the dating but we found it interesting to calculate the variation $x$ in time that could induce a change of the trend of accumulation rates between two consecutive stratal units. This variation gives some information about a limiting value above which the shape of the accumulation rate curve becomes inverted and thus implies changes in the interpretation.

Given the volume and deposition period of $N$ strata in a sedimentary basin $\left(V_{i}, \Delta t_{i}\right), i=1 \ldots N$, let $x_{i}$ be the uncertainty in time between strata $i$ and $i+1$. A change in the accumulation rate pattern between the two strata will occur when

$\left(\frac{V}{\Delta t}\right)_{i}-\left(\frac{V}{\Delta t}\right)_{i+1}=0$

that is, when

$\frac{V_{i}}{\Delta t_{i}-x}-\frac{V_{i+1}}{\Delta t_{i+1}+x}=0$.

This corresponds to a time limit $x$ of the form

$|x|=\left|\frac{V_{i+1} t_{i}-V_{i} t_{i+1}}{V_{i}+V_{i+1}}\right|$.
Table 3 gives the values of $x$ corresponding to the volumes estimated in the sedimentary basins of Asia (Table 2). These values are not an expression of the uncertainty in age and cannot be interpreted as such. Rather, they are intended to give some idea of the fragility/robustness of our results.

A second point concerns the scatter and accuracy of the data used to reconstruct the mass balance. Stratigraphic data in the Cenozoic basins of Asia are not precise, and knowledge of the sediment composition and approximate age is limited to the borders of the basins. Drilling in the deep sea is rare and seldom reaches the basement of a basin. Where we did not have access to seismic or geological sections, sedimentary ratios (eq. 10) that we derive and use to compute the mass balance are biased by platform stratigraphy and may introduce large but unquantifiable uncertainties in the results. Nevertheless, this technique is the only existing reconstruction method that ensures conservative calculations of the volumes stored in the basins of Asia.

A third and last point regarding dating concerns the age limits of epochs. We used the GSA timescale (Palmer 1983) to derive rates from our reconstruction of the sediment volumes because this timescale is currently one of the most used in the literature. Future improvements of the database will incorporate variations in age limits, especially for the Palaeocene-Eocene, Eocene-Oligocene, Early to Late Oligocene and possibly Oligo-Miocene boundaries (Odin 1994), although these changes do not lead to a very different pattern of mass balance (see discussion).

The temporal resolution of our reconstructions is at best 2 Myr. This corresponds to the smallest time interval for which we were able to gather data all around Asia. The spatial resolution corresponds to grid squares with a surface area $\mathrm{S} \approx 100 \mathrm{~km}^{2}$. The results that we obtain are to be viewed as averages in time and space $(\Delta V / \Delta t)$. Clearly, much greater accumulation rates may exist on shorter scales, thus the use of the term 'accumulation rates' is intended to remind one that the reconstructions are the algebraic sum of the deposition and erosion that take place during a certain time span:

$\frac{\Delta V}{\Delta t}=\frac{1}{\Delta t} \int_{\Delta t}\left(\int_{x} \int_{y} \frac{\partial z}{\partial t} d x d y\right) d t$

Table 3. Time variations (or dating errors) required to change the pattern of the accumulation rates curves of Figs 17-19. When two numbers are given they correspond to the time fluctuations between the considered and the overlying strata (left value) and the underlying strata (right value).

\begin{tabular}{|c|c|c|c|c|c|c|c|c|c|}
\hline Epoch (Ma) & $0-2$ & $2-5$ & $5-11$ & $11-17$ & $17-24$ & $24-30$ & $30-37$ & $37-58$ & $58-66$ \\
\hline Indus & 1.29 & $1.29 / 0.40$ & $0.40 / 0.14$ & $0.14 / 0.70$ & $0.70 / 0.36$ & $0.36 / 0.27$ & $0.27 / 1.33$ & $1.33 / 1.60$ & 1.60 \\
\hline Pakistan & 0.56 & $0.56 / 0.55$ & $0.55 / 0.18$ & $0.18 / 0.37$ & $0.37 / 0.93$ & $0.93 / 0.13$ & $0.13 / 3.23$ & $3.23 / 5.57$ & 5.57 \\
\hline Ganga & 0.08 & $0.08 / 1.08$ & $1.08 / 1.58$ & $1.58 / 2.01$ & $2.01 / 3.47$ & $3.47 / 2.57$ & $2.57 / 0.18$ & $0.18 / 1.03$ & 1.03 \\
\hline Bengal & 0.11 & $0.11 / 0.99$ & $0.99 / 0.16$ & $0.16 / 0.79$ & $0.79 / 2.10$ & $2.10 / 0.06$ & $0.06 / 0.90$ & $0.90 / 2.79$ & 2.79 \\
\hline Burma & 0.40 & $0.40 / 2.24$ & $2.24 / 0.88$ & $0.88 / 0.06$ & $0.06 / 0.92$ & $0.92 / 0.09$ & $0.09 / 3.01$ & $3.01 / 5.20$ & 5.20 \\
\hline Andaman & 0.08 & $0.08 / 1.71$ & $1.71 / 0.74$ & $0.74 / 0.67$ & $0.67 / 0.82$ & $0.82 / 3.79$ & $3.79 / 2.35$ & $2.35 / 2.97$ & 2.97 \\
\hline Mergui \& Sumatra & 2.19 & $2.19 / 0.35$ & $0.35 / 0.62$ & $0.62 / 0.41$ & $0.41 / 1.65$ & $1.65 / 0.41$ & $0.41 / 9.36$ & $9.36 / 3.14$ & 3.14 \\
\hline G. of Thailand & 0.01 & $0.01 / 0.04$ & $0.04 / 1.34$ & $1.34 / 1.41$ & $1.41 / 3.08$ & $3.08 / 6.11$ & $6.11 / 20.81$ & $20.81 / 11.62$ & 11.62 \\
\hline Malay \& W. Natuna & 0.06 & $0.06 / 0.23$ & $0.23 / 0.97$ & $0.97 / 1.19$ & $1.19 / 1.17$ & $1.17 / 2.58$ & $2.58 / 20.51$ & $20.51 / 7.69$ & 7.69 \\
\hline Mekong \& Nam Consom & 0.19 & $0.19 / 0.46$ & $0.46 / 0.92$ & $0.92 / 1.16$ & $1.16 / 1.40$ & $1.40 / 0.69$ & $0.69 / 18.70$ & $18.70 / 1.61$ & 1.61 \\
\hline Sarawak \& Sabah & 0.08 & $0.08 / 0.99$ & $0.99 / 0.02$ & $0.02 / 2.78$ & $2.78 / 0.19$ & $0.19 / 0.19$ & $0.19 / 8.07$ & $8.07 / 1.40$ & 1.40 \\
\hline Yinggehai & 1.31 & $1.31 / 0.29$ & $0.29 / 0.84$ & $0.84 / 0.92$ & $0.92 / 0.94$ & $0.94 / 1.55$ & $1.55 / 9.67$ & $9.67 / 4.09$ & 4.09 \\
\hline Zhu \& S. Taiwan & 0.32 & $0.32 / 0.48$ & $0.48 / 2.86$ & $2.86 / 0.84$ & $0.84 / 2.20$ & $2.20 / 1.41$ & $1.41 / 0.43$ & $0.43 / 6.80$ & 6.80 \\
\hline China Sea \& N. Taiwan & 0.38 & $0.38 / 4.37$ & $4.37 / 0.46$ & $0.46 / 2.02$ & $2.02 / 2.27$ & $2.27 / 3.21$ & $3.21 / 4.83$ & $4.83 / 8.29$ & 8.29 \\
\hline Okinawa & 0.80 & $0.80 / 4.77$ & $4.77 / 3.01$ & $3.01 / 0.66$ & $0.66 / 0.62$ & $0.62 / 0.55$ & $0.55 / 3.25$ & $3.25 / 10.33$ & 10.33 \\
\hline Yellow Sea & 0.03 & $0.03 / 4.43$ & $4.43 / 1.97$ & $1.97 / 0.51$ & $0.51 / 5.51$ & $5.51 / 1.46$ & $1.46 / 0.22$ & $0.22 / 11.13$ & 11.13 \\
\hline Bohai & 0.07 & $0.07 / 2.93$ & $2.93 / 0.57$ & $0.57 / 0.10$ & $0.10 / 1.57$ & $1.57 / 3.69$ & $3.69 / 4.62$ & $4.62 / 6.42$ & 6.42 \\
\hline
\end{tabular}


where $d z / d t$ is the rate of variation of the depositional surface within the basin $-d z / d t<0$ means erosion, $d z / d t>0$ means sedimentation. In the following we will always speak of solidphase accumulation rates, referred to as SPAR, so that it is clear that we derived mass accumulation rates through the compaction of rocks.

The history that we describe is intended to be an order of magnitude more precise than previously published mass balances (Curray 1991; Le Pichon et al. 1992; Rea 1992; Einsele et al. 1996). However, its minimum resolution prevents it from being used on a local scale.

\section{RECONSTITUTION OF THE SEDIMENTARY SIGNAL}

Figs 6 to 14 represent the mean SPAR in Asia during nine epochs of the Cenozoic: 66-58, 58-37, 37-30, 30-24, 24-17, 17-11, 11-5, 5-2 and 2-0 Ma. The nine time intervals that we have defined correspond approximately to the following geological limits: Palaeocene, Eocene, lower and upper Oligocene, lower, middle and upper Miocene, Pliocene and Quaternary (Palmer 1983). Figs 15 to 19 show the resulting accumulation rate curves for 17 sedimentary basins of Asia (locations shown in Figs 1 and 2). The volumes of compacted rocks (or solid phase) are given in Table 4 with their relative uncertainties (Table 5).

\subsection{The Palaeocene ( $\approx 66-58 \mathrm{Ma})$}

During the Palaeocene (Fig. 6) there was significant sedimentation in the two largest sedimentary basins of Asia, the Bengal and the Indus fans. Maximum SPAR were 0.21 and $0.23 \mathrm{~mm} \mathrm{yr}^{-1}$ respectively. In the Indus fan, especially in Pakistan, the sediment is carbonate (Lackhra and Lockhart formations), in good agreement with the palaeolatitude of the Indian continent at this time (Pakistan would be in the carbonate accumulation zone of Chamley 1988). Detrital accumulations (sandstones of the Khadro and Hangu formations and clastic formations overlying the traps along the western platform of India) could result from the erosion of India, Madagascar, Arabia or even Africa.

In the case of the Bengal fan, the former Indian continent, encompassing India and the lands to the north that were shortened by the collision process, is the only possible source of sediment for the fan. Carbonates occur along the margin of India. They may, as in the case of the Indus fan, correspond to accumulation in the $10^{\circ}-20^{\circ}$ latitudinal band. Weathering products of the traps were transported on the eastern border of India, whereas at present the materials eroded from the traps are carried away to the west, mainly by the Narmada river.

Considering the relatively high rates of SPAR, we cannot rule out the possibility that the sediments we dated as Palaeocene are in part Cretaceous in the deep fan [note the differences in thickness between maps drawn by Rabinowitz et al. (1988) and Curray (1991, 1994)]. The basement of the central part of the fan has never been reached and there is some continuity between Cretaceous and Palaeocene deposits on the eastern margin of India. The volumes $\left(1.6 \times 10^{6} \mathrm{~km}^{3}\right)$ and accumulation rates we derived for the Palaeocene may thus be overestimated.

Rapid SPAR in Burma, up to $0.65 \mathrm{~mm} \mathrm{yr}^{-1}$, are significant. Detrital deposits (Kabaw molassic formation) persist from the Late Cretaceous throughout the Palaeocene and are related to some tectonic event affecting the drainage area of these basins. To the north in the Chindwin basin the earliest sediments are locally slightly older than Late Cretaceous.

To the east, there is no significant sedimentation in the basins surrounding Indochina except in the Sabah trough (Crocker formation) to the north of Borneo and in the northern part of the Yinggehai basin, where Palaeocene deposits are known from the Gulf of Tonkin (red beds of the Chengliu formation in the Beibu and Hanoi basins). SPAR in these basins are less than $0.1 \mathrm{~mm} \mathrm{yr}^{-1}$. In the East China Sea the Palaeocene was a time of spreading along normal, approximately north-south faults, and rapid sedimentation occurred

Table 4. Solid phase volume accumulated in the Cenozoic sedimentary basins of Asia during nine periods of the Cenozoic. Volumes are in km ${ }^{3}$ of compacted rocks, ages are in $10^{6} \mathrm{yr}$. Basins of Central Asia include the Dzungar, Tarim and Qaidam and Hexi corridor basins. Specific information can be found in Métivier \& Gaudemer (1997) and Métivier et al. (1998). Only the first two digits are considered significant.

\begin{tabular}{|c|c|c|c|c|c|c|c|c|c|c|}
\hline Epoch (Ma) & $0-2$ & $2-5$ & $5-11$ & $11-17$ & $17-24$ & $24-30$ & $30-37$ & $37-58$ & $58-66$ & Total \\
\hline Indus & $3.4 \times 10^{5}$ & $1.7 \times 10^{5}$ & $2.9 \times 10^{5}$ & $2.7 \times 10^{5}$ & $4.0 \times 10^{5}$ & $3.1 \times 10^{5}$ & $3.3 \times 10^{5}$ & $7.8 \times 10^{5}$ & $3.8 \times 10^{5}$ & $3.3 \times 10^{6}$ \\
\hline Pakistan & $1.9 \times 10^{4}$ & $1.8 \times 10^{4}$ & $2.8 \times 10^{4}$ & $3.0 \times 10^{4}$ & $3.1 \times 10^{4}$ & $2.0 \times 10^{4}$ & $2.4 \times 10^{4}$ & $1.5 \times 10^{5}$ & $1.4 \times 10^{5}$ & $4.6 \times 10^{5}$ \\
\hline Gange & $5.3 \times 10^{4}$ & $7.5 \times 10^{4}$ & $2.7 \times 10^{5}$ & $1.6 \times 10^{5}$ & $1.0 \times 10^{5}$ & $2.4 \times 10^{4}$ & $1.2 \times 10^{4}$ & $3.6 \times 10^{4}$ & $1.6 \times 10^{4}$ & $7.5 \times 10^{5}$ \\
\hline Bengal & $9.0 \times 10^{5}$ & $1.2 \times 10^{6}$ & $1.5 \times 10^{6}$ & $1.5 \times 10^{6}$ & $1.3 \times 10^{6}$ & $5.8 \times 10^{5}$ & $6.8 \times 10^{5}$ & $2.5 \times 10^{6}$ & $1.5 \times 10^{6}$ & $1.2 \times 10^{7}$ \\
\hline Burma & $7.7 \times 10^{4}$ & $8.3 \times 10^{4}$ & $6.0 \times 10^{4}$ & $4.4 \times 10^{4}$ & $5.1 \times 10^{4}$ & $3.3 \times 10^{4}$ & $3.7 \times 10^{4}$ & $2.2 \times 10^{5}$ & $1.9 \times 10^{5}$ & $7.9 \times 10^{5}$ \\
\hline Andaman & $2.7 \times 10^{5}$ & $3.9 \times 10^{5}$ & $3.5 \times 10^{5}$ & $2.7 \times 10^{5}$ & $2.6 \times 10^{5}$ & $2.9 \times 10^{5}$ & $9.4 \times 10^{4}$ & $1.9 \times 10^{5}$ & $1.1 \times 10^{5}$ & $2.2 \times 10^{6}$ \\
\hline Mergui \& Sumatra & $3.9 \times 10^{5}$ & $7.5 \times 10^{4}$ & $1.3 \times 10^{5}$ & $1.0 \times 10^{5}$ & $1.4 \times 10^{5}$ & $6.8 \times 10^{4}$ & $7.0 \times 10^{4}$ & $5.0 \times 10^{4}$ & $3.1 \times 10^{4}$ & $1.1 \times 10^{6}$ \\
\hline Malay \& W. Natuna & $3.8 \times 10^{4}$ & $6.0 \times 10^{4}$ & $1.1 \times 10^{5}$ & $1.5 \times 10^{5}$ & $1.2 \times 10^{5}$ & $1.5 \times 10^{5}$ & $7.6 \times 10^{4}$ & $1.4 \times 10^{3}$ & $1.5 \times 10^{1}$ & $7.0 \times 10^{5}$ \\
\hline Mekong \& Nam Consom & $5.6 \times 10^{4}$ & $7.2 \times 10^{4}$ & $1.8 \times 10^{5}$ & $1.3 \times 10^{5}$ & $1.1 \times 10^{5}$ & $6.0 \times 10^{4}$ & $8.7 \times 10^{4}$ & $7.8 \times 10^{3}$ & $2.2 \times 10^{3}$ & $7.2 \times 10^{5}$ \\
\hline Sarawak \& Sabah & $2.2 \times 10^{5}$ & $3.1 \times 10^{5}$ & $3.9 \times 10^{5}$ & $3.9 \times 10^{5}$ & $1.9 \times 10^{5}$ & $1.5 \times 10^{5}$ & $1.9 \times 10^{5}$ & $1.6 \times 10^{5}$ & $4.7 \times 10^{4}$ & $2.1 \times 10^{6}$ \\
\hline Yinggehai & $2.3 \times 10^{5}$ & $1.2 \times 10^{5}$ & $2.0 \times 10^{5}$ & $1.5 \times 10^{5}$ & $1.3 \times 10^{5}$ & $8.6 \times 10^{4}$ & $6.2 \times 10^{4}$ & $4.2 \times 10^{4}$ & $3.0 \times 10^{4}$ & $1.1 \times 10^{6}$ \\
\hline Zhu \& S. Taiwan & $8.1 \times 10^{4}$ & $9.3 \times 10^{4}$ & $2.4 \times 10^{5}$ & $8.5 \times 10^{4}$ & $1.3 \times 10^{5}$ & $5.3 \times 10^{4}$ & $4.0 \times 10^{4}$ & $1.3 \times 10^{5}$ & $5.6 \times 10^{3}$ & $8.6 \times 10^{5}$ \\
\hline E. China Sea \& N. Taiwan & $1.9 \times 10^{5}$ & $2.0 \times 10^{5}$ & $4.5 \times 10^{4}$ & $3.9 \times 10^{4}$ & $8.8 \times 10^{4}$ & $3.6 \times 10^{4}$ & $1.5 \times 10^{4}$ & $1.7 \times 10^{5}$ & $2.2 \times 10^{5}$ & $1.0 \times 10^{6}$ \\
\hline Okinawa & $1.3 \times 10^{5}$ & $9.9 \times 10^{4}$ & $1.6 \times 10^{4}$ & $5.2 \times 10^{3}$ & $4.9 \times 10^{3}$ & $5.1 \times 10^{3}$ & $5.0 \times 10^{3}$ & $3.3 \times 10^{4}$ & $5.6 \times 10^{4}$ & $3.5 \times 10^{5}$ \\
\hline Yellow Sea & $2.9 \times 10^{4}$ & $4.4 \times 10^{4}$ & $9.3 \times 10^{3}$ & $4.7 \times 10^{3}$ & $6.4 \times 10^{3}$ & $5.0 \times 10^{4}$ & $3.7 \times 10^{4}$ & $1.2 \times 10^{5}$ & $2.3 \times 10^{5}$ & $5.2 \times 10^{5}$ \\
\hline Central Asia & $2.4 \times 10^{5}$ & $6.8 \times 10^{5}$ & $3.0 \times 10^{5}$ & $3.6 \times 10^{5}$ & $1.4 \times 10^{5}$ & $5.0 \times 10^{4}$ & $5.0 \times 10^{4}$ & $1.0 \times 10^{5}$ & $4.0 \times 10^{4}$ & $1.9 \times 10^{6}$ \\
\hline Total & $3.3 \times 10^{6}$ & $3.8 \times 10^{6}$ & $4.2 \times 10^{6}$ & $3.8 \times 10^{6}$ & $3.3 \times 10^{6}$ & $2.0 \times 10^{6}$ & $1.8 \times 10^{6}$ & $4.8 \times 10^{6}$ & $2.9 \times 10^{6}$ & $3.0 \times 10^{7}$ \\
\hline
\end{tabular}




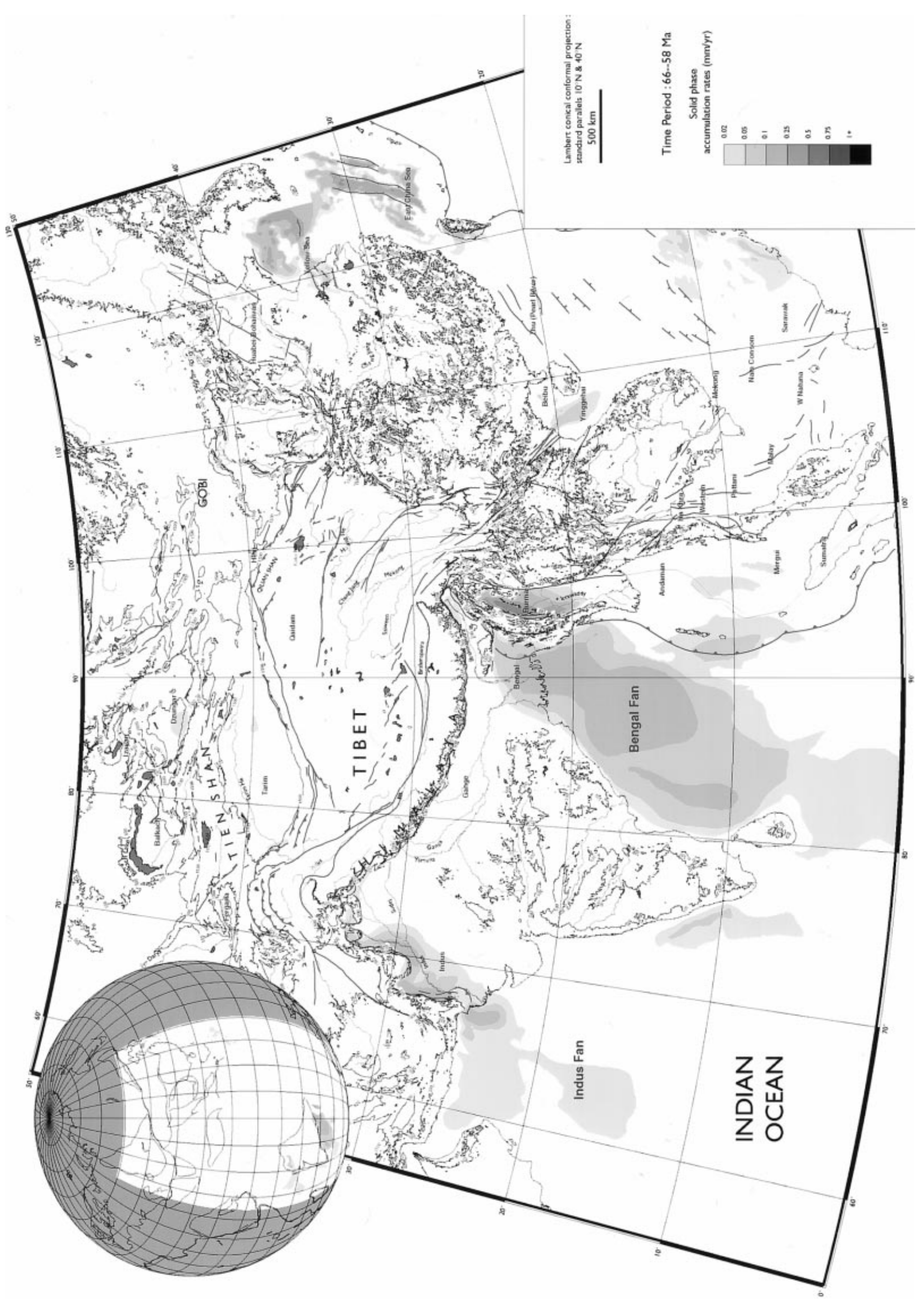

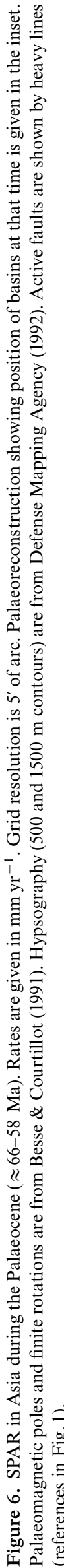

(C) 1999 RAS, GJI 137, 280-318 


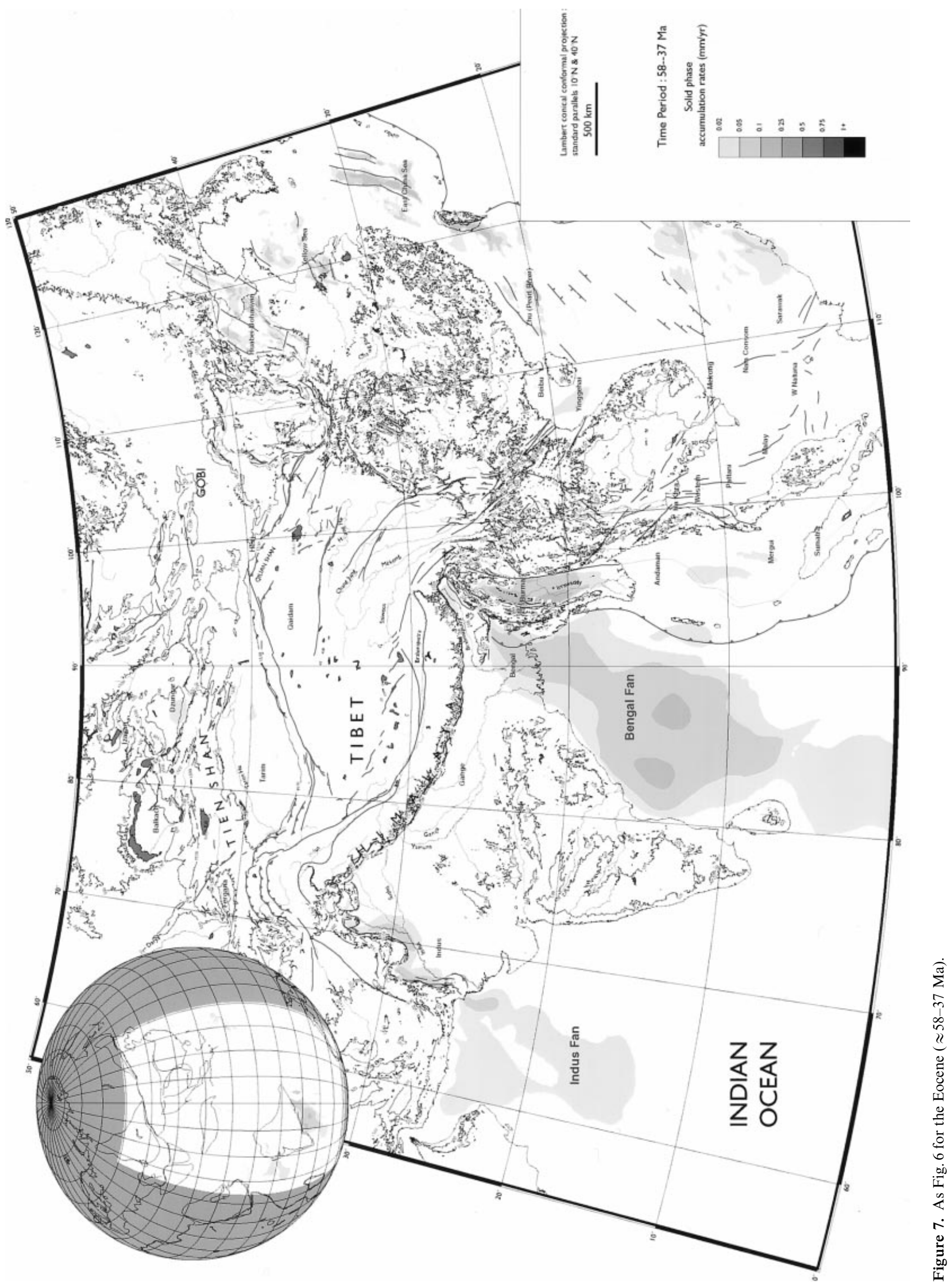

(C) 1999 RAS, GJI 137, 280-318 


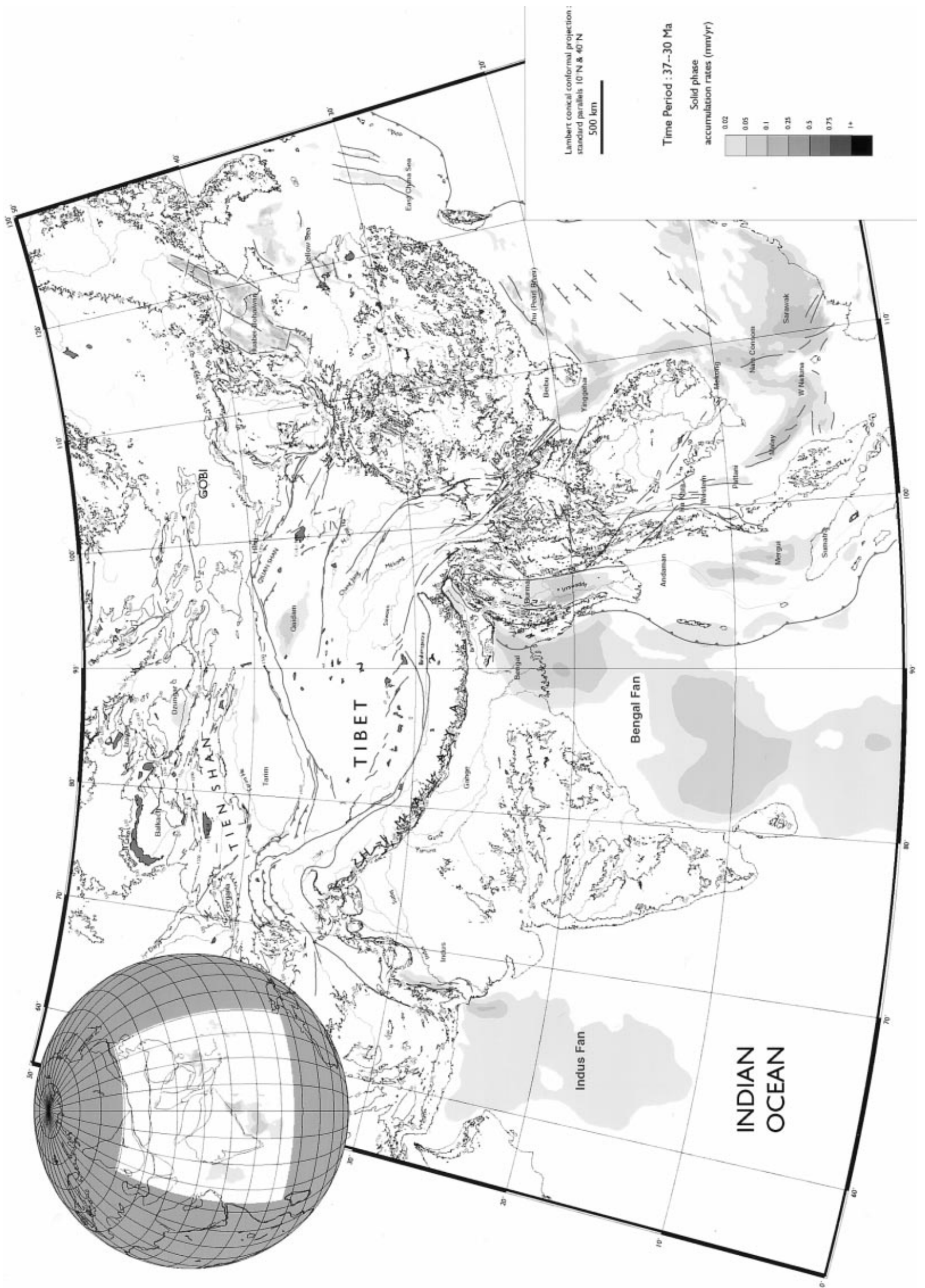

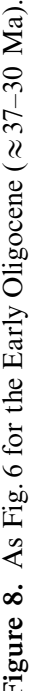




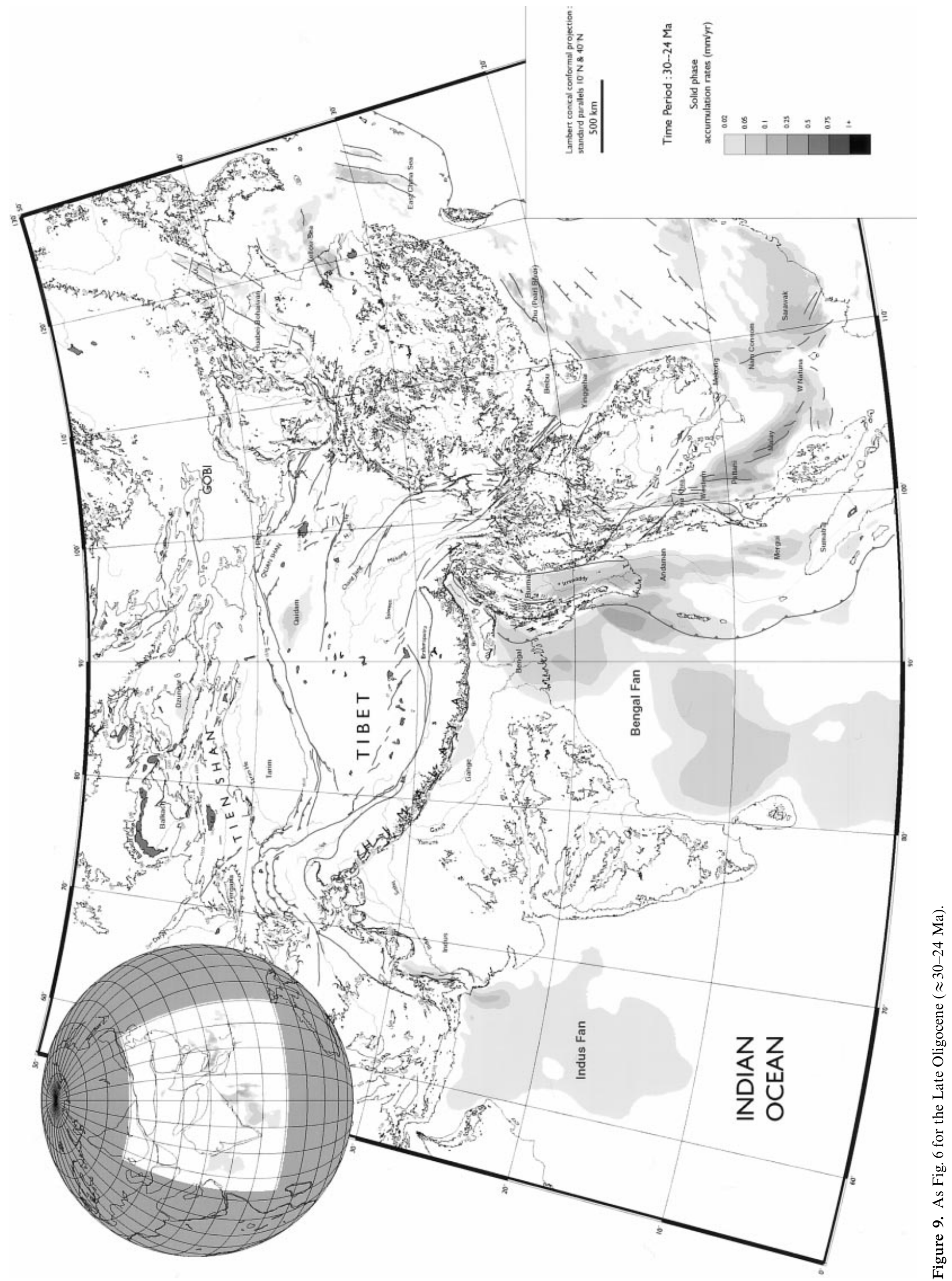

(C) 1999 RAS, GJI 137, 280-318 


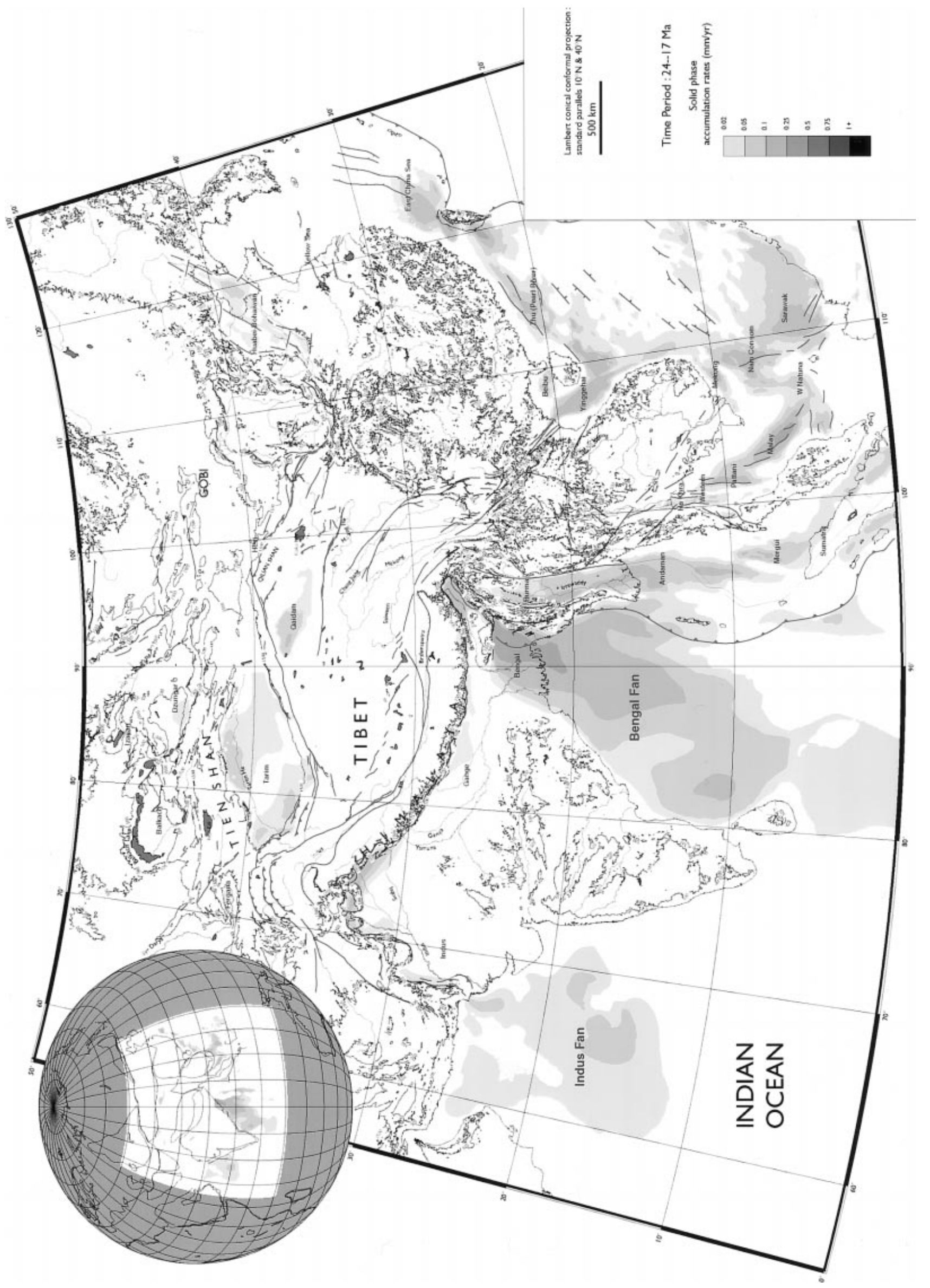

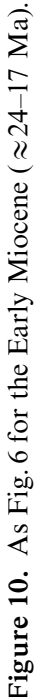




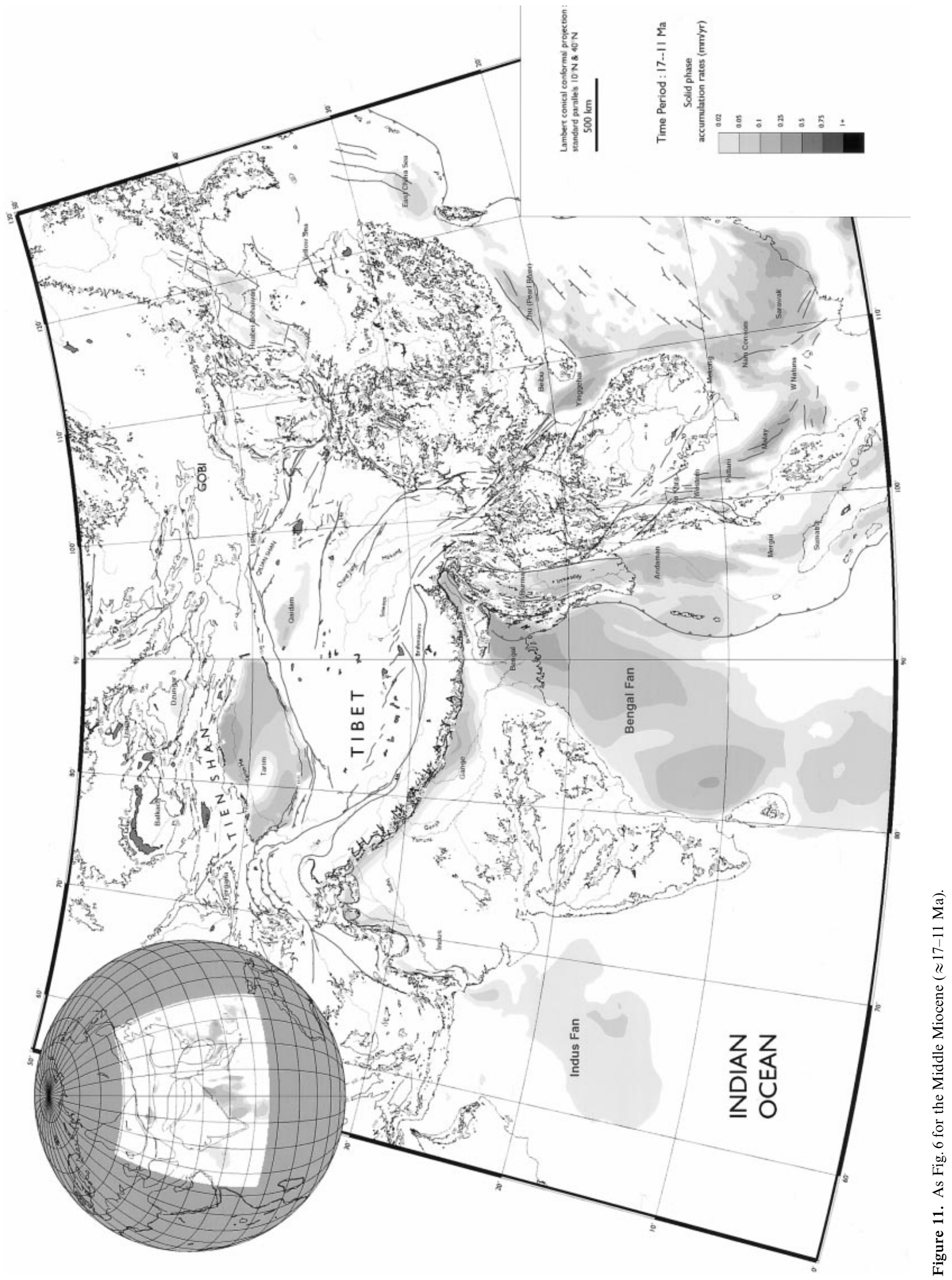

(C) 1999 RAS, GJI 137, 280-318 


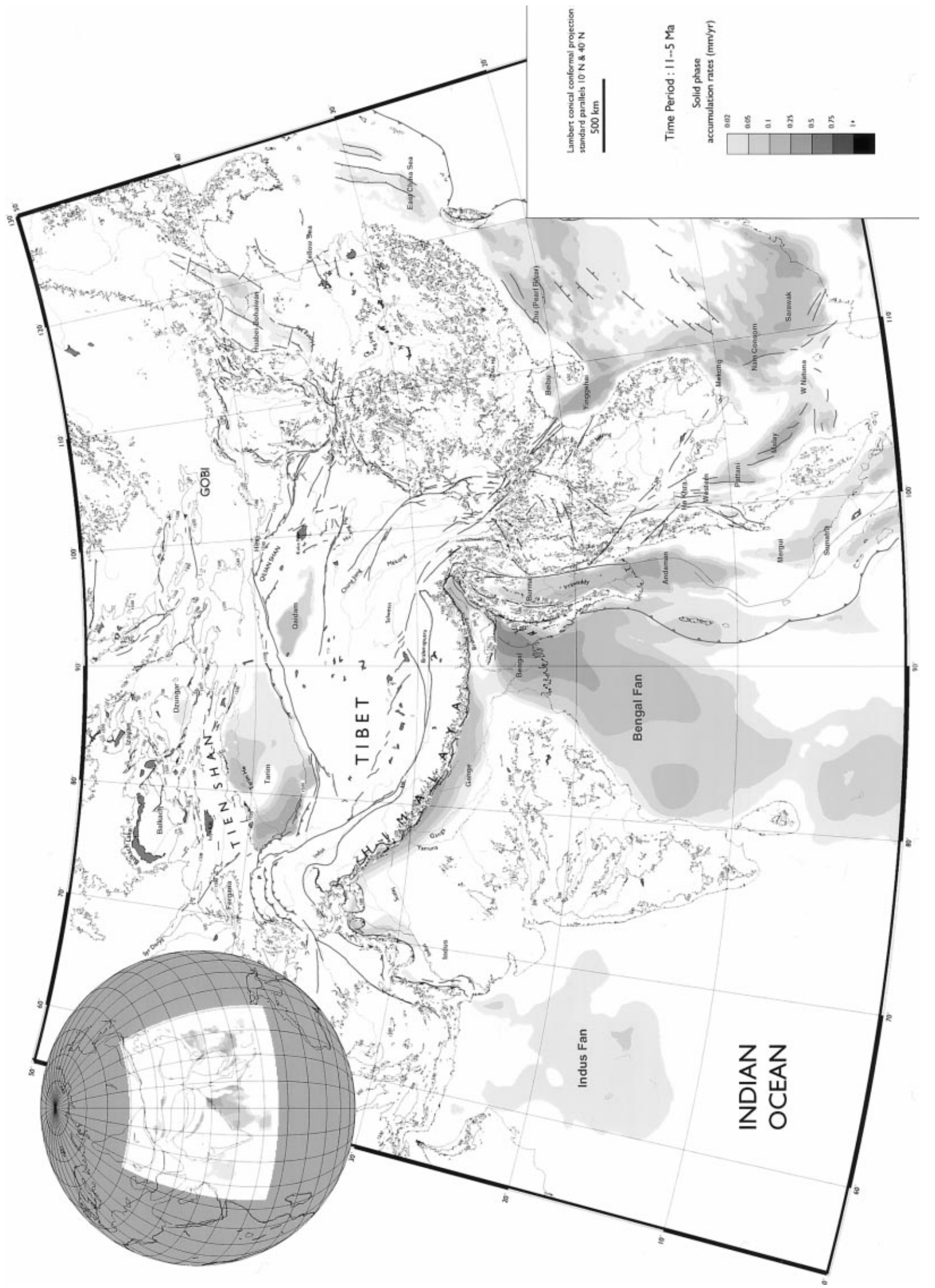

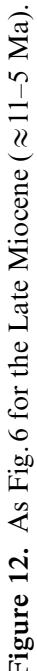




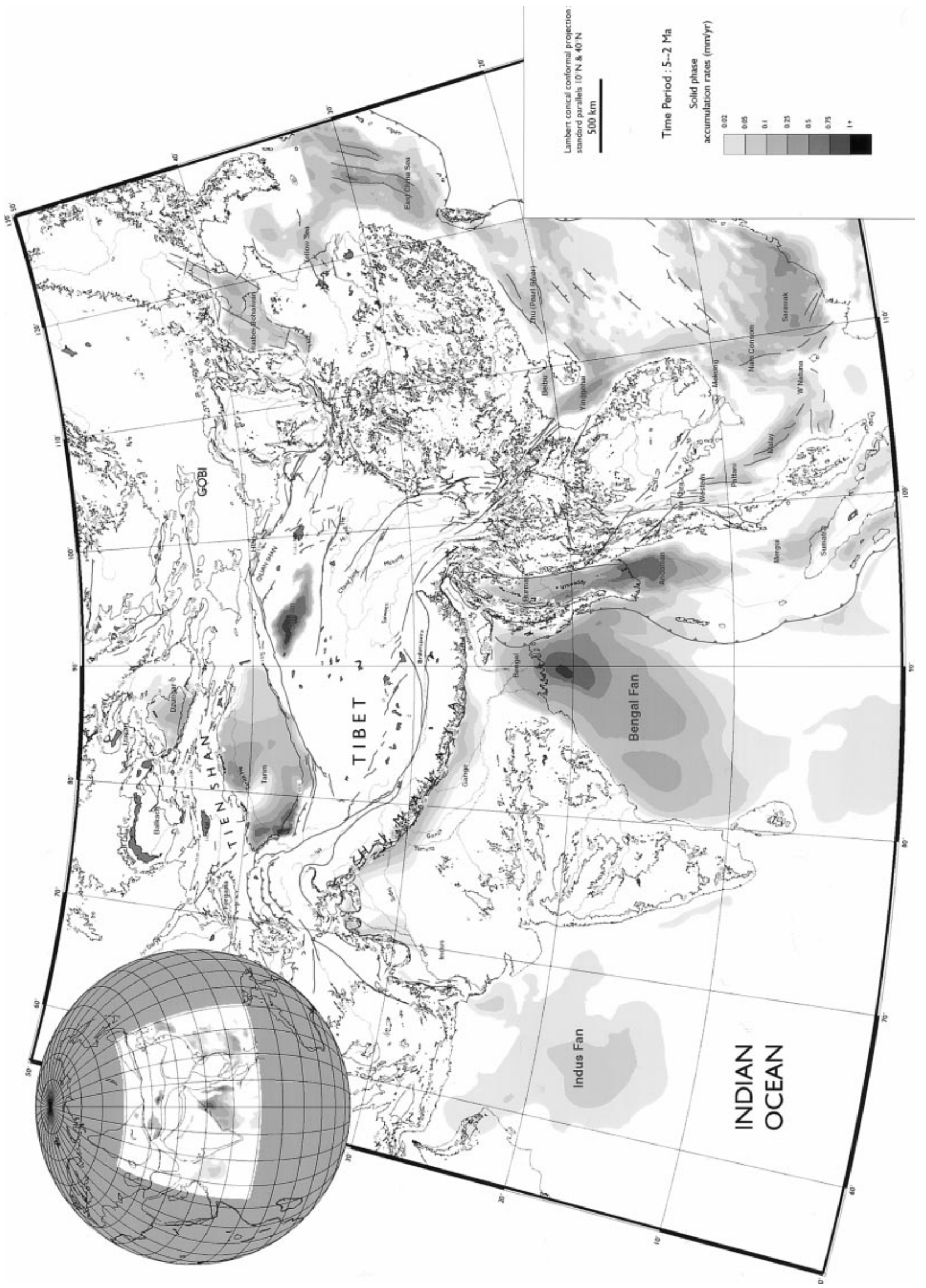

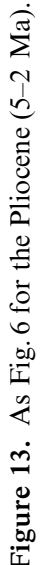




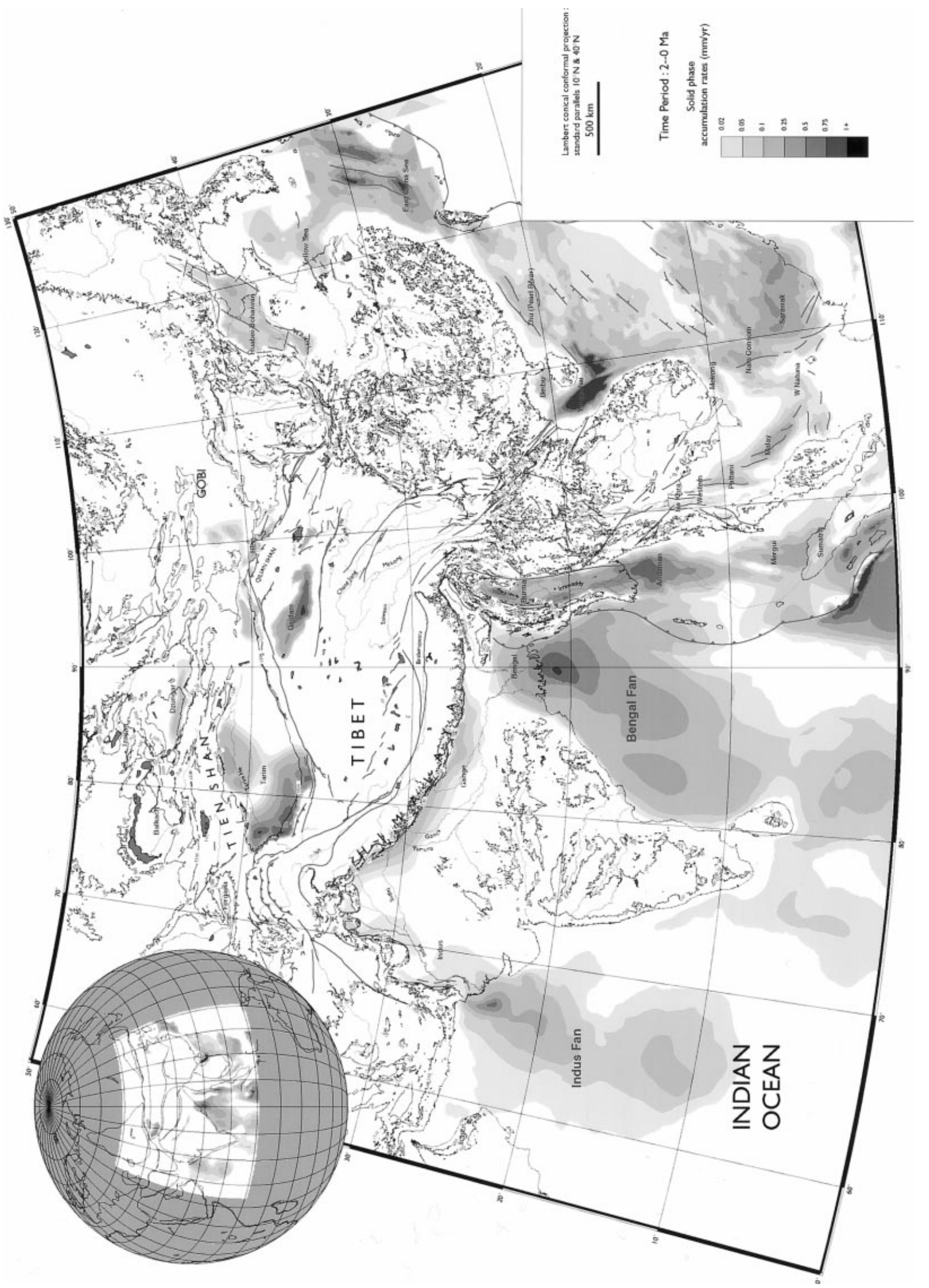

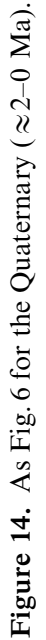



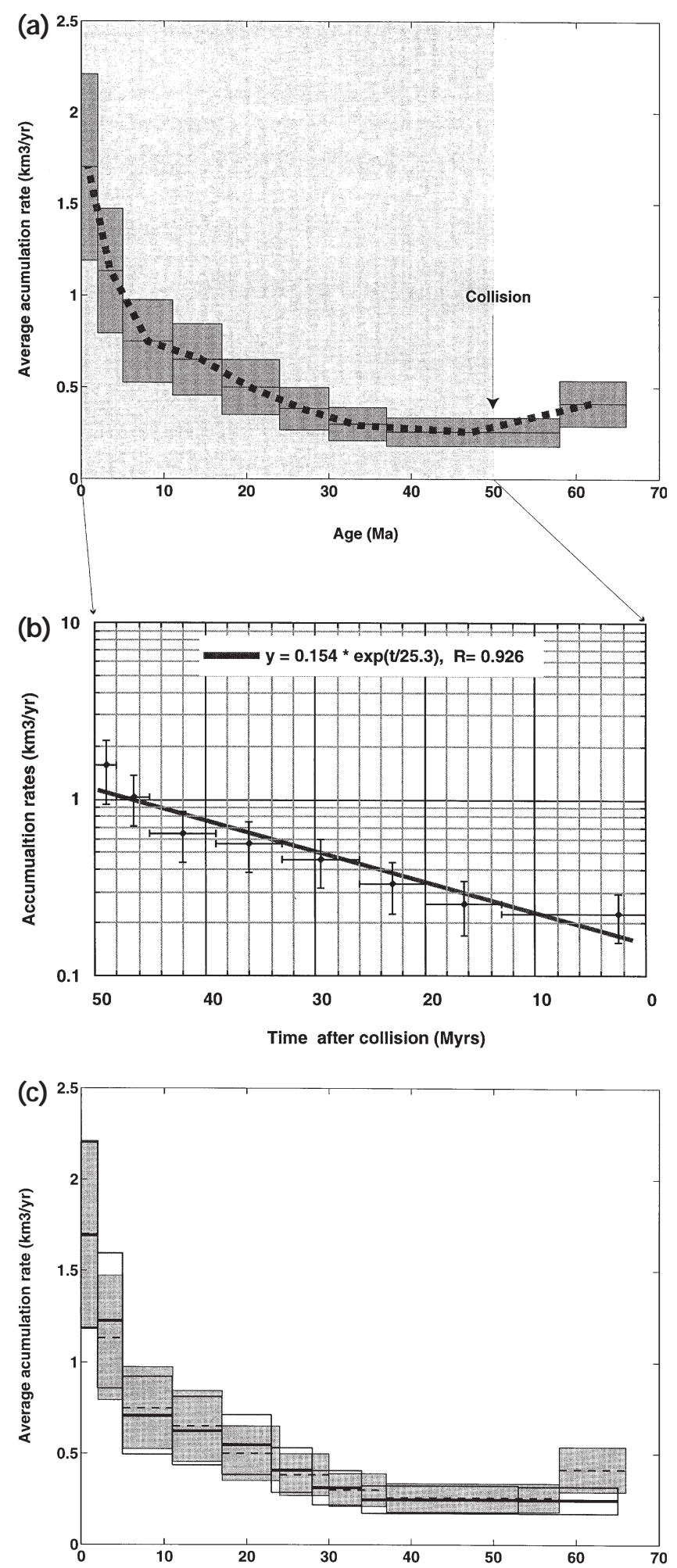

Figure 15. (a) Average SPAR integrated over all basins of Asia. $x$-axis: age in Ma; $y$-axis: rates in $\mathrm{km}^{3} \mathrm{yr}^{-1}$. Dotted line joining midpoints shows general trend of SPAR. Grey-shaded boxes represent calculation uncertainty. (b) Average fit of SPAR starting from $50 \mathrm{Ma}$ (average age assumed for collision between India and Asia; Patriat \& Achache 1984) with an exponential curve. (c) Approximated differences in SPAR induced by use of the Odin (1994) timescale (black lines and empty squares) compared to SPAR obtained using the GSA timescale (Palmer 1983; dotted lines and filled squares). in the associated depressions such as the East China Sea basin. There, rates of accumulation ( Linfeng, Oujiang and Pinghu formations) reached $0.66 \mathrm{~mm} \mathrm{yr}^{-1}$.

\subsection{The Eocene $(\approx 58-37 \mathrm{Ma})$}

The period between 58 and $37 \mathrm{Ma}$ coincides with uniform accumulation over the entire Asian realm (Figs 7 and 15). In Burma the maximum rates dropped to $0.2 \mathrm{~mm} \mathrm{yr}^{-1}$. Average SPAR are less then $0.1 \mathrm{~mm} \mathrm{yr}^{-1}$ with maxima of $0.2 \mathrm{~mm} \mathrm{yr}^{-1}$. East of China, accumulation extended to the Hubei basin at the present-day mouth of the Huang He (this sedimentation seems coeval with extension along NE-SW-trending normal faults). To the south of the East China Sea, extension took place in the Pearl River Basin and grabens began to form where fluvial deposits begin to accumulate (Zuhai formation).

Off Oman there was some extension of the Indus fan to the east and a major reduction of accumulation along the western margin of India.

It is during this $21 \mathrm{Myr}$ period that the collision between India and Asia most probably began. From the analysis of magnetic anomalies in the Indian Ocean, Patriat \& Achache (1984) found a major slowing of the convergence rate (from 15 to $5 \mathrm{~cm} \mathrm{yr}^{-1}$ ) between India and Asia at about $50 \mathrm{Ma}$. Based on palaeomagnetism, Besse et al. (1984) derived a palaeoposition of $57 \mathrm{Ma}$ Eocene limestones of Tibet of $2^{\circ} \mathrm{S}$. The samples they studied showed a second magnetization at $6^{\circ} \mathrm{N}$ at the end of a folding stage. Studying the wander path of these rocks along the margin of India, Besse et al. (1984) derived the same age as Patriat \& Achache (1984). Plate tectonic reconstructions of Besse \& Courtillot (1988) converge towards the same pattern, with a collision time between 53 and $48 \mathrm{Ma}$. However, there is some evidence that the collision could have taken place even earlier, around $60 \mathrm{Ma}$. Jaeger et al. (1990) reported the presence of Pelobatid frogs and Plaeoryctid mammals of Eurasian origin in sediments intercalated between the flood basalts of the Deccan Traps. This suggests contacts between the two continents, allowing these animals to migrate. From an analysis of stratigraphy in Waziristan and Kuram further north, Beck et al. (1995) suggested that the collision zone in the Thal region was located further to the south than previously thought (Carbonnel 1977 cited in Beck et al. 1995). All these results indicate an age of collision bracketed between the Palaeocene and the Eocene. We assume a 50 Ma collision age, realizing that this is probably a minimum.

The shortening in Asia induced by the penetration of India involves three mechanisms: crustal shortening, lateral escape of blocks (extrusion) and possibly some crustal subduction (Tapponnier et al. 1986; Peltzer \& Tapponnier 1988; Leloup et al. 1995; Mattauer 1986). Of these three mechanisms, shortening and crustal subduction lead to uplift and formation of significant relief. Reduction of SPAR between the Palaeocene and Eocene and persistent low rates during the Eocene do not favour a massive uplift throughout Asia. However, over such a long period the average rate $\left(0.22 \mathrm{~mm} \mathrm{yr}^{-1}\right)$ that we derive may not be statistically significant and a major part of the sediment record could have accumulated after the onset of collision, say after $50 \mathrm{Ma}$. In this case average SPAR for the late Eocene would be of $0.36 \mathrm{~mm} \mathrm{yr}^{-1}$, equivalent to the Palaeocene SPAR $\left(0.36 \mathrm{~mm} \mathrm{yr}^{-1}\right)$, slightly higher than the lower Oligocene SPAR $\left(0.26 \mathrm{~mm} \mathrm{yr}^{-1}\right)$ and even the entire Oligocene SPAR $\left(0.33 \mathrm{~mm} \mathrm{yr}^{-1}\right)$. The collision would then be marked by a 
Table 5. Uncertainty associated with the estimate of the mass accumulated in the Cenozoic sedimentary basins of Asia (Table 2). Volumes are in $\mathrm{km}^{3}$; ages are in $10^{6}$ yr. For basins of Central Asia see Métivier \& Gaudemer (1997), and Métivier et al. (1998).

\begin{tabular}{|c|c|c|c|c|c|c|c|c|c|c|}
\hline Epoch (Ma) & $0-2$ & $2-5$ & $5-11$ & $11-17$ & $17-24$ & $24-30$ & $30-37$ & $37-58$ & $58-66$ & Total \\
\hline Indus & $1.8 \times 10^{5}$ & $7.5 \times 10^{4}$ & $1.2 \times 10^{5}$ & $1.1 \times 10^{5}$ & $1.5 \times 10^{5}$ & $1.2 \times 10^{5}$ & $1.3 \times 10^{5}$ & $3.1 \times 10^{5}$ & $1.6 \times 10^{5}$ & $1.4 \times 10^{6}$ \\
\hline Pakistan & $9.8 \times 10^{3}$ & $7.3 \times 10^{3}$ & $1.1 \times 10^{4}$ & $1.1 \times 10^{4}$ & $1.2 \times 10^{4}$ & $7.0 \times 10^{3}$ & $8.5 \times 10^{3}$ & $6.0 \times 10^{4}$ & $5.4 \times 10^{4}$ & $1.8 \times 10^{5}$ \\
\hline Ganga & $2.4 \times 10^{4}$ & $2.8 \times 10^{4}$ & $1.1 \times 10^{5}$ & $5.7 \times 10^{4}$ & $3.5 \times 10^{4}$ & $8.6 \times 10^{3}$ & $4.4 \times 10^{3}$ & $1.3 \times 10^{4}$ & $5.7 \times 10^{3}$ & $2.8 \times 10^{5}$ \\
\hline Bengal & $2.8 \times 10^{5}$ & $3.3 \times 10^{5}$ & $4.3 \times 10^{5}$ & $4.1 \times 10^{5}$ & $3.7 \times 10^{5}$ & $1.7 \times 10^{5}$ & $2.0 \times 10^{5}$ & $7.2 \times 10^{5}$ & $4.2 \times 10^{5}$ & $3.3 \times 10^{6}$ \\
\hline Burma & $2.2 \times 10^{4}$ & $2.1 \times 10^{4}$ & $1.5 \times 10^{4}$ & $1.1 \times 10^{4}$ & $1.3 \times 10^{4}$ & $8.6 \times 10^{3}$ & $9.7 \times 10^{3}$ & $6.0 \times 10^{4}$ & $5.0 \times 10^{4}$ & $2.1 \times 10^{5}$ \\
\hline daman & $9.4 \times 10^{4}$ & $1.1 \times 10^{5}$ & $1.1 \times 10^{5}$ & $8.9 \times 10^{4}$ & $8.1 \times 10^{4}$ & $9.0 \times 10^{4}$ & $3.3 \times 10^{4}$ & $6.4 \times 10^{4}$ & $4.3 \times 10^{4}$ & $7.1 \times 10^{5}$ \\
\hline Mergui \& Sun & $2.0 \times 10^{5}$ & $3.0 \times 10^{4}$ & $5.2 \times 10^{4}$ & $4.0 \times 10^{4}$ & $5.4 \times 10^{4}$ & $2.6 \times 10^{4}$ & $2.6 \times 10^{4}$ & $1.9 \times 10^{4}$ & $1.2 \times 10^{4}$ & $4.6 \times 10^{5}$ \\
\hline G. of Thailand & $5.0 \times 10^{3}$ & $6.6 \times 10^{3}$ & $1.3 \times 10^{4}$ & $2.1 \times 10^{4}$ & $1.5 \times 10^{4}$ & $3.5 \times 10^{4}$ & $2.5 \times 10^{3}$ & $1.8 \times 10^{1}$ & $2.4 \times 10^{1}$ & $9.8 \times 10^{4}$ \\
\hline alay \& W. Natuna & $1.4 \times 10^{4}$ & $2.0 \times 10^{4}$ & $3.4 \times 10^{4}$ & $4.8 \times 10^{4}$ & $3.9 \times 10^{4}$ & $4.9 \times 10^{4}$ & $2.6 \times 10^{4}$ & $5.0 \times 10^{2}$ & $1.6 \times 10^{1}$ & $2.3 \times 10^{5}$ \\
\hline Mekong \& Nam Consom & $2.3 \times 10^{4}$ & $2.5 \times 10^{4}$ & $6.4 \times 10^{4}$ & $4.6 \times 10^{4}$ & $3.9 \times 10^{4}$ & $2.2 \times 10^{4}$ & $3.1 \times 10^{4}$ & $2.9 \times 10^{3}$ & $7.9 \times 10^{2}$ & $2.5 \times 10^{5}$ \\
\hline Sarawak & $7.6 \times 10^{4}$ & $9.0 \times 10^{4}$ & $1.1 \times 10^{5}$ & $1.1 \times 10^{5}$ & $5.6 \times 10^{4}$ & $4.5 \times 10^{4}$ & $5.6 \times 10^{4}$ & $5.0 \times 10^{4}$ & $1.5 \times 10^{4}$ & $6.2 \times 10^{5}$ \\
\hline Yinggehai & $7.4 \times$ & $3.3 \times 10^{4}$ & $5.8 \times 10^{4}$ & $4.5 x$ & $4.1 \times 10^{4}$ & $2.6 \times 10^{4}$ & $1.9 \times 10^{4}$ & $1.2 \times 10^{4}$ & $8.9 \times 10^{3}$ & $3.2 \times 10^{5}$ \\
\hline Zhu \& S. Taiwan & $4.0 \times 10^{4}$ & $3.8 \times 10^{4}$ & $1.0 \times 10^{5}$ & $3.1 \times 10^{4}$ & $4.9 \times 10^{4}$ & $1.5 \times 10^{4}$ & $1.2 \times 10^{4}$ & $3.3 \times 10^{4}$ & $1.4 \times 10^{3}$ & $3.3 \times 10^{5}$ \\
\hline E. China Sea \& N. Taiwan & $8.1 \times 10^{4}$ & $7.5 \times 10^{4}$ & $1.6 \times 10^{4}$ & $1.2 \times 10^{4}$ & $3.1 \times 10^{4}$ & $8.1 \times 10^{3}$ & $3.3 \times 10^{3}$ & $4.3 \times 10^{4}$ & $5.7 \times 10^{4}$ & $3.2 \times 10^{5}$ \\
\hline Okinawa & $6.4 \times 10^{4}$ & $4.0 \times 10^{4}$ & $6.0 \times 10^{3}$ & $2.0 \times 10^{3}$ & $2.1 \times 10^{3}$ & $9.6 \times 10^{2}$ & $9.8 \times 10^{2}$ & $7.8 \times 10^{3}$ & $1.3 \times 10^{4}$ & $1.4 \times 10^{5}$ \\
\hline Yellow Sea & $2.4 \times 10^{4}$ & $2.9 \times 10^{4}$ & $4.9 \times 10^{3}$ & $2.2 \times 10^{3}$ & $2.9 \times 10^{3}$ & $1.3 \times 10^{4}$ & $1.0 \times 10^{4}$ & $3.4 \times 10^{4}$ & $6.5 \times 10^{4}$ & $1.9 \times 10^{5}$ \\
\hline 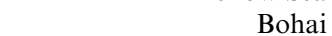 & & $2.4 \times 10^{4}$ & $1.1 \times$ & 9.2 & $1.1 \times 10^{4}$ & $5.8 \times$ & $3.0>$ & 4.3 & $2.4 \times 10^{3}$ & $1.5 \times 10^{5}$ \\
\hline Central Asia & $1.0 \times 10^{5}$ & $2.6 \times 10^{5}$ & $1.1 \times 10^{5}$ & $1.4 \times 10^{5}$ & $5.0 \times 10^{4}$ & $2.0 \times 10^{4}$ & $2.0 \times 10^{4}$ & $4.0 \times 10^{4}$ & $1.0 \times 10^{4}$ & $7.5 \times 10^{5}$ \\
\hline Total & $1.3 \times 10^{6}$ & $1.2 \times 10^{6}$ & $1.4 \times 10^{6}$ & $1.1 \times 10^{6}$ & $1.0 \times 10^{6}$ & $6.5 \times 10^{5}$ & $6.0 \times 10^{5}$ & $1.5 \times 10^{6}$ & $9.0 \times 10^{5}$ & $9.8 \times 10^{6}$ \\
\hline
\end{tabular}
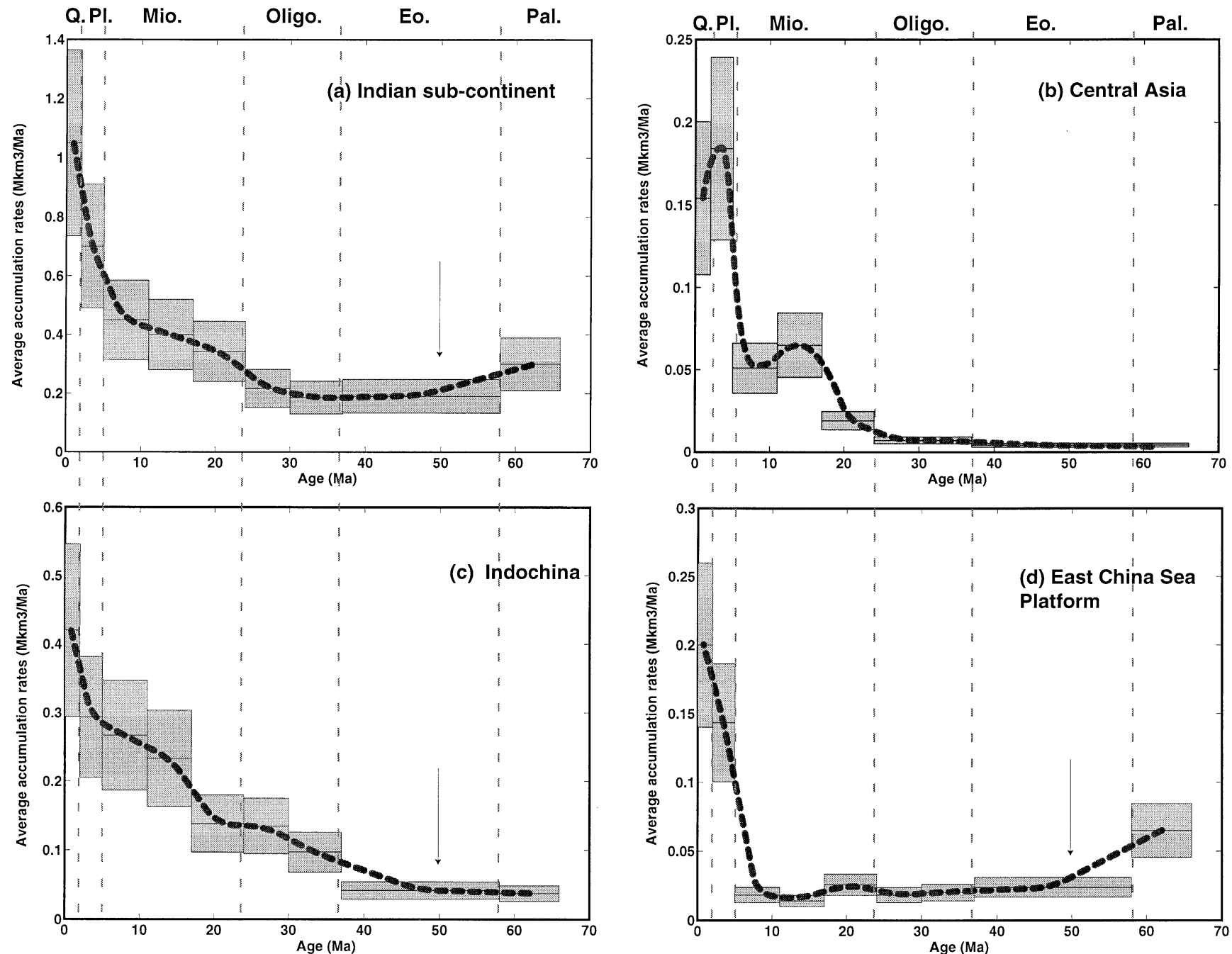

Figure 16. Average SPAR integrated over four subsets of Cenozoic basins of Asia. (a) Basins of Indian subcontinent; (b) basins of Central Asia; (c) basins of Indochina; (d) basins of East China Sea. $x$-axis: age in Ma; $y$-axis: rates in $\mathrm{km}^{3} \mathrm{yr}^{-1}$. Dotted line joining mid-points shows general trend of SPAR. Grey-shaded boxes represent calculation uncertainty. 

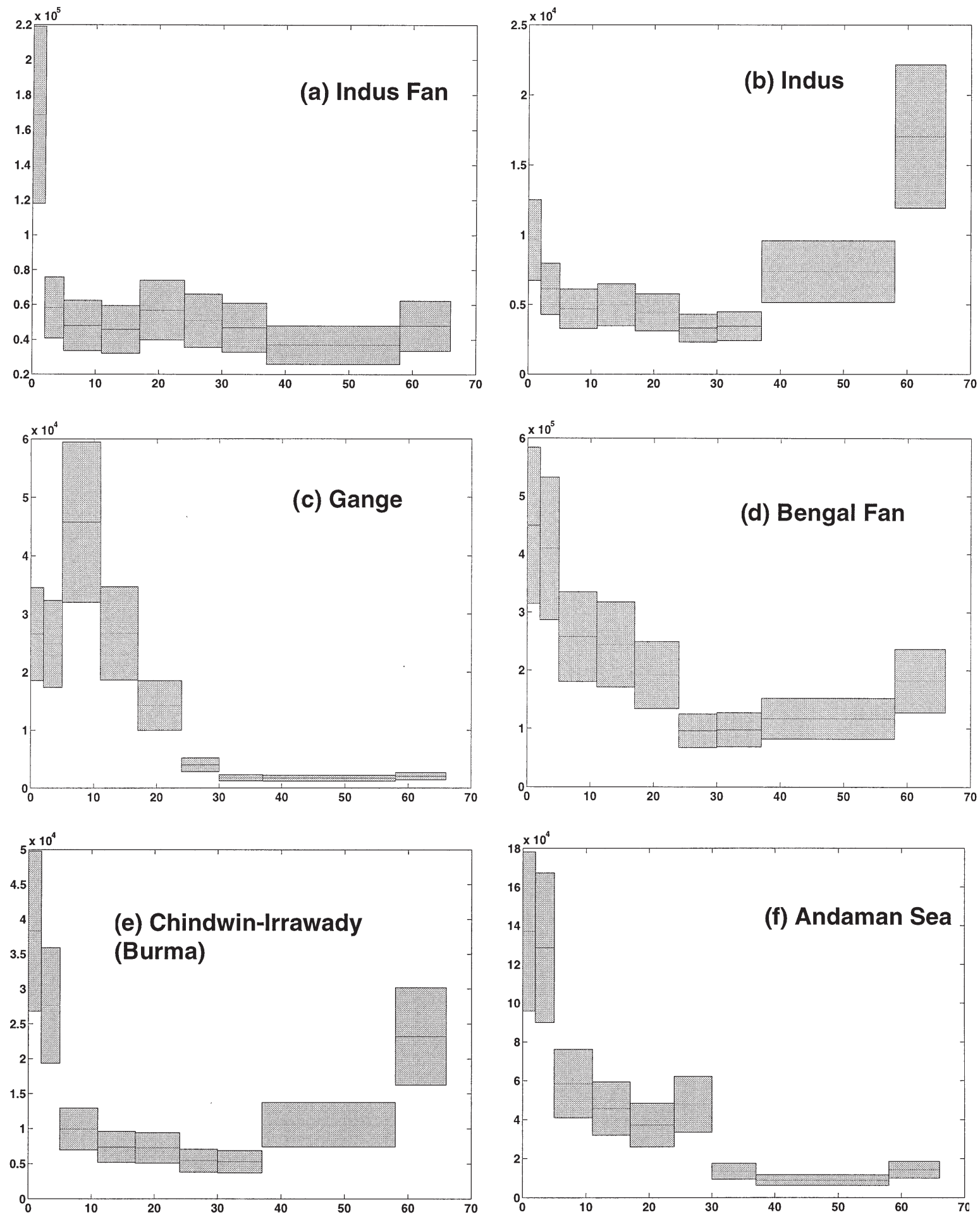

Figure 17. Average SPAR integrated over each major depositional area of reconstruction. $x$-axis: age in Ma; $y$-axis: rates in $\mathrm{km}^{3} \mathrm{yr}^{-1}$. Grey-shaded boxes represent calculation uncertainty.

rise in SPAR that would attest for some uplift component. However, two comments can be made: (1) these rates are smaller than the Miocene and more recent SPAR, suggesting that either uplift was maybe not the major accommodating process of the shortening induced by the collision or that the geometry of the collision was not the same as the present-day geometry so that surface shortening may have been less than it is today; and (2) the SPAR differences we are discussing can hardly be considered significant within the error bars even if one takes into account the sediments now incorporated into mountain ranges such as the Makran and Indo-Burman mountains (see Section 5.2). 

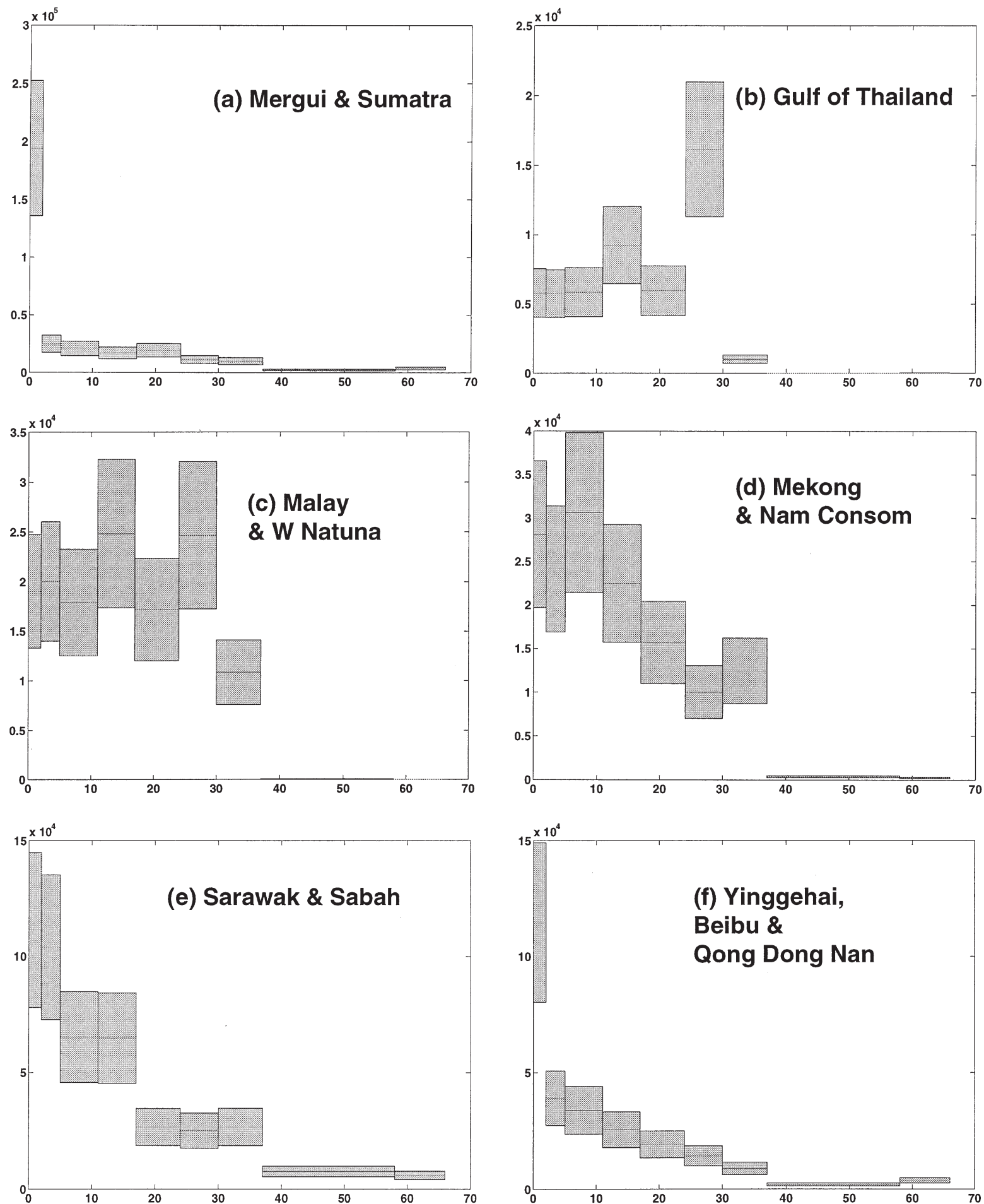

Figure 18. As Fig. 17.

\subsection{The Oligocene ( $\approx 37-24 \mathrm{Ma})$}

The Early Oligocene was a time of major changes in the geography of sedimentation in Asia (Fig. 8). First, it was the time of opening of the South China Sea when accumulation along the Indian margin spread to the south and extended to the Sibolga basin west of Sumatra. It was also the time when SPAR in the Bengal fan reached their minimum value.

In the East China Sea, accumulation was confined to the grabens formed during the beginning of the Tertiary. Deposits are fluvio-lacustrine (Huangang formation). However, south of Taiwan, clastic sedimentation did not occur prior to the Oligocene. To the south of Indochina, the Gulf of Thailand and the Malay basins began to form. Near Kalimantan, the sedimentation that had been confined in the Sabah Trough extended to the entire Sarawak basin. To the north of Vietnam, 

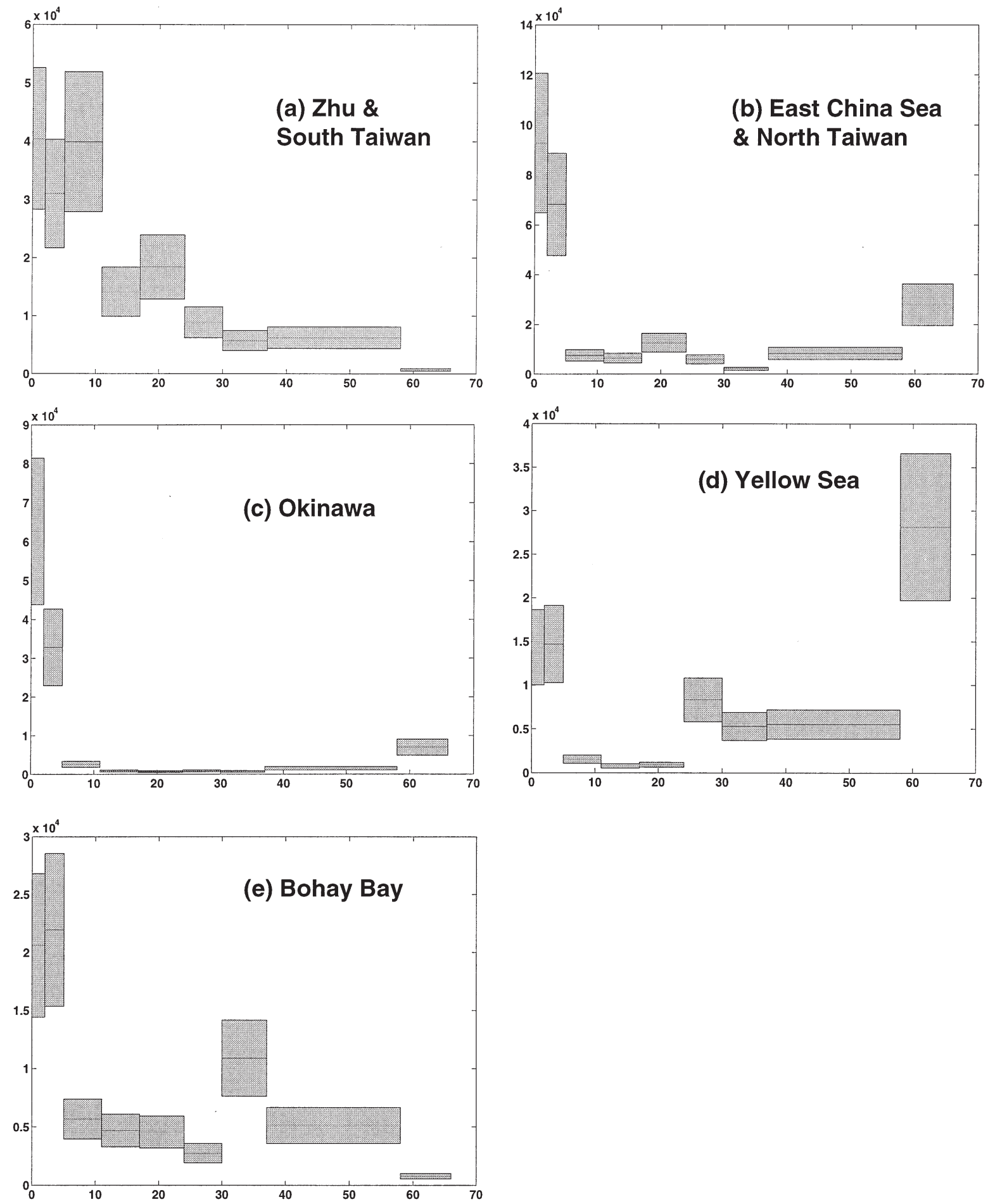

Figure 19. As Fig. 17.

sedimentation extended throughout the Yinggehai basin, the eastern margin of Vietnam and to the Qongdongnan basin on the southern margin of Hainan Island. Deposits were lacustrine (Liushagang formation); rates were of the order of $0.1 \mathrm{~mm} \mathrm{yr}^{-1}$ with a maximum at $0.24 \mathrm{~mm} \mathrm{yr}^{-1}$.

From 30-24 Ma, during the late Oligocene (Fig. 9), SPAR rose in the Gulf of Thailand, around the Andaman Islands and in the eastern part of the Bengal fan, east of the Ninety-
East Ridge, where sandstones of the Port Blair formation accumulated. Rates increased from 0.19 to $0.49 \mathrm{~mm} \mathrm{yr}^{-1}$ in the Gulf of Thailand and from 0.15 to $0.36 \mathrm{~mm} \mathrm{yr}^{-1}$ in the Andaman Sea. To the north of the Indochina peninsula sedimentation prograded towards the centre of the South China Sea. In the Yellow Sea SPAR increased slightly. The basins of Subei and of the East China Sea were connected as they had been during the Palaeocene. 
An important feature of the late Oligocene was the appearance of sedimentation in the Ganga basin with the accumulation of the Subathu formation; rates were low, less than $0.05 \mathrm{~mm} \mathrm{yr}^{-1}$. The Indus fan seems to have grown continuously since the Eocene; maximum rates were $0.13 \mathrm{~mm} \mathrm{yr}^{-1}$. This growth of the fan was coeval with deposition of the Nari formation in the lower Indus basin, with the sand percentage increasing towards the top.

\subsection{The Miocene $(\approx 24-5 \mathrm{Ma})$}

During the Early Miocene (Fig. 10), between 24 and 17 Ma, a major depocentre formed in front of the Shillong plateau and the Indo-Burman ranges bordering the Bengal Basin. SPAR were of the order of $0.2 \mathrm{~mm} \mathrm{yr}^{-1}$ with maxima of $0.4 \mathrm{~mm} \mathrm{yr}^{-1}$. Sediments were detrital but coarse facies do not predominate (Surma group, claystones of Pandua and Matla). In the Ganga basin depocentres formed especially in Potwar, where the first molasse deposits (Murree formation) started to accumulate. Rates were of the order of $0.12 \mathrm{~mm} \mathrm{yr}^{-1}$ with maxima at $0.29 \mathrm{~mm} \mathrm{yr}^{-1}$. To the north of the Tibetan plateau, in front of the Kunlun ranges in the Tarim and Qaidam basins, accumulation rates rose from 0.05 to $0.1 \mathrm{~mm} \mathrm{yr}^{-1}$. Rates were higher in the western part of the range (Tarim) than in the eastern part (Qaidam) (Métivier \& Gaudemer 1997; Métivier et al. 1998).

In Indonesia, back-arc basins began to form and sandstones accumulated (Nias formation). In the Gulf of Thailand, rates of accumulation diminished everywhere except in the central part of the Malay basin, where maximum rates were of the order of $0.32 \mathrm{~mm} \mathrm{yr}^{-1}$. This slow-down coincided with the stratigraphic hiatus defining the limit between cycles I and II. At the same time SPAR rose in the Gulf of Tonkin and the first conglomerates began to accumulate (Weizhou and Xiayang formations). Deposition continued to prograde towards the centre of the South China Sea, which was still undergoing extension. To the north there was a small increase in the basins surrounding Taiwan and in the southern part of the East China Sea basin; maximum rates reached $0.39 \mathrm{~mm} \mathrm{yr}^{-1}$. To the north of this region, including the Yellow Sea, SPAR decreased to less than $0.01 \mathrm{~mm} \mathrm{yr}^{-1}$. The Bohai Bay basin was the ongoing site of fluvio-lacustrine sediment accumulation.

Between 17 and $11 \mathrm{Ma}$, during the Middle Miocene (Fig. 11), SPAR rose everywhere in southeastern Asia. The most spectacular changes took place in the Sarawak and Sabah basins, north of Borneo. Rates of deposition of carbonates and shallow-water detrital materials changed from 0.17 to $0.4 \mathrm{~mm} \mathrm{yr}^{-1}$. The Yinggehai basin also experienced an increase in SPAR, to a maximum of $0.34 \mathrm{~mm} \mathrm{yr}^{-1}$ from $0.21 \mathrm{~mm} \mathrm{yr}^{-1}$. To the north of the Pearl River, SPAR dropped, although the sediment remained conglomeratic. In the Andaman sea, rates increased. In the Malay Basin turbidites accumulated (Trang formation). In the Ganga Basin the Siwalik molasse deposits began to accumulate with maximum rates of about $0.27 \mathrm{~mm} \mathrm{yr}^{-1}$. In the Indus basin there was progradation of the deposits towards the south and regression of fan sedimentation in the west. In the Bengal fan, east of the Coromandel Coast and north of Ceylon, depocentres started to fill quickly at rates of the order of $0.26 \mathrm{~mm} \mathrm{yr}^{-1}$ (earlier they had been $0.11 \mathrm{~mm} \mathrm{yr}^{-1}$ ). In Central Asia, the northern part of the Tarim experienced a sharp increase in SPAR, coeval with the deposition of the first conglomerates (Métivier \&
Gaudemer 1997). Rates of accumulation also rose in the south but not as significantly. In the Qaidam basin, there was a small increase in the rates of accumulation of the Ganchaigou formation (Métivier et al. 1998).

During the Late Miocene (Fig. 12), between 11 and 5 Ma, SPAR in the East China Sea rose again. Significant deposition began in the Okinawa Basin [note that CCOP (1991) argue that there was no sedimentation there before the Pliocene, $5 \mathrm{Ma}$. SPAR increased in the Pearl River basin (where deposits were continuously coarse), in the Yinggehai basin north of Indochina and in the Nam Consom and Mekong basins southeast of the peninsula. In the East China Sea the maximum rates of accumulation were less than $0.11 \mathrm{~mm} \mathrm{yr}^{-1}$, while they were less than $0.47 \mathrm{~mm} \mathrm{yr}^{-1}$ in the South China Sea. In the Andaman Sea, maximum rates increased slightly from 0.23 to $0.28 \mathrm{~mm} \mathrm{yr}^{-1}$ as the environment deepened. SPAR of the Siwaliks increased all along the Himalayan front, with southward progradation of the deposits. In central Asia, the southern depression of Tarim was, like the Ganga plain, the site of an increase in accumulation rates, coeval with the onset of sandstone deposition in the piedmont of the Kunlun Range (Pakablak group). Maximum rates changed from 0.22 to $0.43 \mathrm{~mm} \mathrm{yr}^{-1}$ in the southwestern depression. In the northern part of the basin, maximum rates dropped from 0.5 to $0.27 \mathrm{~mm} \mathrm{yr}^{-1}$. In the Qaidam, in front of the eastern Kunlun ranges, rates continued to increase, reaching $0.2 \mathrm{~mm} \mathrm{yr}^{-1}$.

\subsection{The Pliocene ( $\approx 5-2 \mathrm{Ma})$}

The Pliocene was a time of general increase in SPAR throughout the Asian realm with maximum SPAR rising from 0.7 to $1.17 \mathrm{~mm} \mathrm{yr}^{-1}$ (Fig. 13). A depocentre formed in the Gulf of Bohai, where accumulation rates were up to $0.44 \mathrm{~mm} \mathrm{yr}^{-1}$. To the south in the East China Sea, the maximum increased from 0.11 to $0.8 \mathrm{~mm} \mathrm{yr}^{-1}$. Sandy and silty accumulation took place in the Okinawa basin. In the South China Sea, rates increased, especially in the Qongdongnan, Yinggehai, Sarawak and Sabaha basins; maxima there were about 0.4, 0.58, 0.69 and $0.65 \mathrm{~mm} \mathrm{yr}^{-1}$ respectively. Sedimentation was rapid in the Andaman Sea and in the Irrawady basin. The average rates were of the order of $0.24 \mathrm{~mm} \mathrm{yr}^{-1}$ and maximum rates were $0.92 \mathrm{~mm} \mathrm{yr}^{-1}$. In the Bengal fan, depocentres prograded southwards. Three of them can be recognized. The largest is located at the present-day mouth of the Jamuna River (Ganges-Brahmapoutra). Average and maximum rates were of the order of 0.33 and $1.06 \mathrm{~mm} \mathrm{yr}^{-1}$. The sediments were coarse arenites (Tipam group). In the other two depocentres, located more to the south, finer sediments accumulated at an average rate of $0.18 \mathrm{~mm} \mathrm{yr}^{-1}$. In the Himalayan piedmont, SPAR dropped. The average rates there were low (around $0.22 \mathrm{~mm} \mathrm{yr}^{-1}$ ) and maxima were of the order of $0.35 \mathrm{~mm} \mathrm{yr}^{-1}$ along the mountain front. In central Asia, the Pliocene was also a period of very rapid accumulation. In the Tarim basin rates increased everywhere. In the southwestern depression, where the Anjuan conglomerate accumulated, rates were of the order of $0.17 \mathrm{~mm} \mathrm{yr}^{-1}$. In the depocentres, rates locally reached $1 \mathrm{~mm} \mathrm{yr}^{-1}$. In the Dzungar basin, the maximum rates changed from less than 0.01 to $0.44 \mathrm{~mm} \mathrm{yr}^{-1}$ [although as noted by Métivier \& Gaudemer (1997), one may question the meaning of an average accumulation rate for a $61 \mathrm{Myr}$ period]. To the east, in the Qaidam basin, SPAR of the Youshashan formation experienced a drastic increase, reaching more than 
$1 \mathrm{~mm} \mathrm{yr}^{-1}$ over more than half of the depositional area. To the north, in the Hexi corridor of the Qilian Shan piedmont, foreland accumulation took place at an average rate of $0.2 \mathrm{~mm} \mathrm{yr}^{-1}$ (Métivier et al. 1998).

\subsection{The Quaternary ( $\approx 2-0 \mathrm{Ma})$}

The Quaternary (Fig. 14), like the preceding period, was a time of rapid accumulation in most of the depocentres of Asia. In Central Asia, rates were of the same order as during the Pliocene (maximum rates were $1.04 \mathrm{~mm} \mathrm{yr}^{-1}$ in the Tarim basin and $1.08 \mathrm{~mm} \mathrm{yr}^{-1}$ in the Qaidam basin). In the Dzungar basin to the north, sedimentation slowed down, with maximum rates of $0.16 \mathrm{~mm} \mathrm{yr}^{-1}$. In the East China Sea, rapid accumulation took place at the mouth of the Blue River (Chang Jiang) and in the Okinawa basin, with maximum rates of $1.18 \mathrm{~mm} \mathrm{yr}^{-1}$ and averages around $0.17 \mathrm{~mm} \mathrm{yr}^{-1}$. Everywhere in the South China sea basins accumulation took place at rates higher than $0.1 \mathrm{~mm} \mathrm{yr}^{-1}$. Maximum rates occurred in the Yinggehai basin $\left(1.95 \mathrm{~mm} \mathrm{yr}^{-1}\right)$. In the Sarawak and Sabah basins, the maximum accumulation rate was of the order of $0.65 \mathrm{~mm} \mathrm{yr}^{-1}$, whereas in the Gulf of Thailand to the west it was of the order of $0.42 \mathrm{~mm} \mathrm{yr}^{-1}$. Further to the west, SPAR rose sharply in the Sibolga basin and at the front of the subduction zone. Average SPAR were $0.28 \mathrm{~mm} \mathrm{yr}^{-1}$ with a maximum at $1.83 \mathrm{~mm} \mathrm{yr}^{-1}$. In the Andaman Sea and in Burma accumulation took place in all the depocentres with an average rate of $0.22 \mathrm{~mm} \mathrm{yr}^{-1}$ and maximum rates of $1.02 \mathrm{~mm} \mathrm{yr}^{-1}$. A major depocentre appeared at the mouth of the Indus river, where accumulation took place at rates reaching $0.9 \mathrm{~mm} \mathrm{yr}^{-1}$. In front of the Himalaya, rates of accumulation were similar to the rates of accumulation during the Pliocene, with a maximum of $0.36 \mathrm{~mm} \mathrm{yr}^{-1}$ along the Main Boundary Thrust front.

\section{GENERAL PATTERN OF}

\section{SEDIMENTATION: DISCUSSION}

\subsection{Rise in SPAR and erosion in the catchments}

SPAR distribution in Asia (Fig. 15a) can be subdivided and grouped into four distinct geographical subsets: the Indian subcontinent, Central Asia, the Indochinese peninsula and the Chinese continental margin. Fig. 16 shows the total SPAR in these four regions. These rates, in $\mathrm{km}^{3} \mathrm{yr}^{-1}$, were obtained by integrating the grain volumes over each of the subsets for each period and by dividing by the duration of each epoch.

SPAR were low during the Palaeogene (the first half of the Cenozoic) and reached a maximum during the last 5 Myr. Assuming that the entire volume of Eocene sediments accumulated after the onset of the collision at 50 Ma would not significantly change the overall trend of the curves. This is intriguing if one also assumes that the collision induced rapid and major uplift of mountain ranges in order to accommodate the continental shortening. Integrated over the entire Asian continent, accumulation rates show a continuous rise that can be fitted by an exponential curve of the type

$\frac{d S}{d t}=0.154 \exp \left(\frac{t}{25.3}\right)$,

where $t$ is the time (in Myr) after the onset of collision at $50 \mathrm{Ma}$, and $\tau=25.3$ is the characteristic period of rise of the accumulation rates (Fig. 15b). $\tau$ corresponds to the average period corresponding to a rise in SPAR by a factor of $\mathrm{e} \approx 2.7$. It therefore reflects the time delay between initiation of the collision and significant change in the clastic sedimentation pattern in Asia.

As mentioned above, we used the GSA timescale (Palmer 1983) to establish our balance. Using a more recent timescale such as that of Odin (1994) should not significantly change the volumes accumulated and, within the error bars, the rates derived, because changes in the ages of the limits of epochs do not lead to huge changes in duration of these epochs. An idea of what the rates would be using this timescale can be derived from the values in Table 4 together with new period limits. The trend of the general accumulation rates curves will not change significantly within the error bars (Fig. 15c). Only for the Palaeocene is there a significant change. The SPAR anomaly disappears and rates stay at the same small level throughout the Palaeogene. Slight differences may be expected to appear in the maps depending on the varying time constraints available within each of the hundreds of stratigraphic columns we gathered.

This SPAR curve corresponds to a surface integral of mass accumulations over more than $10^{6} \mathrm{~km}^{2}$. It reflects an overall mechanism that affects most of the Asian catchments. However, it is also the sum of independent histories, as can be clearly seen from the accumulation patterns for each individual basin (Figs 17-19). Thus, interpretation of SPAR depends on our knowledge, at different scales, of erosional and tectonic mechanisms affecting the different drainage areas of the Asian continent.

Continental clastic sedimentation implies relief in the source area. Once the relief exists, it is systematically subjected to weathering and erosion (see e.g. Leeder 1991 for erosion rate estimates for numerous catchments). On a regional scale it has been shown that erosion rates depend on the average elevation of a given catchment above its base level (e.g. Ahnert 1970; Pinet \& Souriau 1988; Summerfield \& Hulton 1994). An interesting statistical analysis on data sets was performed by Fournier (1960), the validity of which has been discussed by Leeder (1991). It showed a dependence of erosion on precipitation, average elevation and slope of the catchment of the form

$\log E=\log \left(\frac{p^{2}}{P}\right)+0.46 \log (H \tan \alpha)-1.56$,

where $E$ is the erosion rate $\left(10^{3} \mathrm{~kg} \mathrm{~km}^{-2} \mathrm{yr}^{-1}\right), P$ is the annual precipitation $(\mathrm{mm}), p$ is the amount of rainfall $(\mathrm{mm})$ during the wettest month, $H$ is the average elevation of the catchment and $\alpha$ is the average slope of the drainage area.

To first order, Fournier's formula shows the power-law dependence of erosion on two terms, one climatic and one hypsographic and hence tectonic because the average elevation is tectonically controlled in actively growing mountain ranges (Métivier \& Gaudemer 1997). We discuss the interactions between these two factors below.

\subsection{Onset of crustal thickening}

The Cenozoic movement of the Indian plate is well constrained (Patriat \& Achache 1984) and exhibits a clear decrease in velocity from 15 to $5 \mathrm{~cm} \mathrm{yr}^{-1}$ at about $50 \mathrm{Ma}$. Since then, 
penetration of India into Asia has been a continuous and constant phenomenon. The convergence rate of India relative to Siberia has remained constant since that time at about $5 \mathrm{~cm} \mathrm{yr}^{-1}$.

According to the simple erosion laws, it is difficult to explain the lack of sedimentary accumulation in Asia if there was young, growing relief all along the collision front or somewhere else in the Asian realm, assuming that, although the present-day monsoonal climate was not established, significant rainfall must have existed (Kutzbach et al. 1989; Ramstein et al. 1997; Fluteau et al. 1999). Furthermore, this absence of sedimentation can hardly be explained by claiming that the sediment accumulated 'somewhere else'. We carefully checked all the major Asian Cenozoic sedimentary basins and there is no record of major Palaeocene and Eocene arc volcanism that would indicate significant sediment subduction at the border of the Indian plate at that time.

Palaeogene sediments (dated from the Palaeocene to the Oligocene and even Miocene) are recorded in the Indo-Burman ranges in the Makran prism and in the ranges of Pakistan. These rocks are no longer in sedimentary areas and cannot be reconstructed using our technique. However, it is possible to derive an estimate of the maximum Palaeogene volume stored in these ranges by assuming that all the present-day topography is made only of Palaeogene sedimentary rocks.

From the database of the Defense Mapping Agency (1992), we find a volume of topography, corresponding to the Makran prism, Pakistan ranges and Indo-Burman ranges, of approximately $5 \times 10^{5} \mathrm{~km}^{3}$. Assuming local isostasy we obtain a total volume (including topography and lithospheric crust) of the order of $3.6 \times 10^{6} \mathrm{~km}^{3}$. Assuming furthermore that this volume is only made of sediments that are already compacted and that it corresponds only to the Palaeocene and Eocene epochs (a crude overestimation) we can derive from this volume a supplementary rate of $0.12 \mathrm{~mm} \mathrm{yr}^{-1}$ to be added to the $0.22 \mathrm{~mm} \mathrm{yr}^{-1}$ derived from mass balance. This would not change significantly the shape of the Asian SPAR curve within the error bars.

Given the present knowledge we have of SPAR in Asia during the Cenozoic, mountain formation, although certainly existing, was probably not the dominant mechanism accommodating the collision-induced shortening during the Palaeogene. Two possibilities remain: subduction of most of the continental crust along the collision front or lateral extrusion of continental blocks along at least crustal-scale strike-slip faults such as the Altyn Tagh and Red River faults. The first hypothesis seems quite unreasonable because, on a mechanical basis, it would be difficult to have large-scale continental subduction without topographic uplift and ensuing erosion. In northeastern Tibet, for example, subduction of the middle and lower Asian crust is correlated with strong uplift and erosion of mountain ranges such as the Kunlun Shan and the Qilian Shan (Tapponnier et al. 1990; Meyer et al. 1998; Métivier et al. 1998). The extrusion mechanism is remarkable in that it provides a simple physical mechanism for accommodating shortening by mostly horizontal movements of mass. Hence, extrusion should lead to little erosion.

Depending on the geometry of the Indian and Asian margins prior to the collision, and assuming that the surface loss remains approximately constant after the collision has begun, the amount of shortening since $50 \mathrm{Ma}$ is between 4 and $8 \times 10^{6} \mathrm{~km}^{2}$ (England \& Houseman 1986; Tapponnier et al.
1986; Le Pichon et al. 1992). If, following these authors, one assumes a constant shortening rate in front of the Indian indentor, then the general curve of Fig. 15 suggests that the extrusion and the crustal thickening processes are complementary mechanisms accommodating the collision-induced shortening. Extrusion thus appears to be predominant in the first million years of the collision. When does it become minor compared to thickening of the crust? Does it stop? What is its proportion in the regional mass balance?

The clastic sedimentation rate shows a progressive rise starting in the Oligocene. Crustal thickening and coeval topographic uplift therefore seem to have been continuous since. The overall shape of the curve is exponential (Figs 16a and 18), with rates culminating during the Quaternary. This result is consistent with the idea that the Himalaya in its present-day configuration is a young mountain range, less than 30 Myr old. Figs 18(e) and (f) show even more significant SPAR changes in Burma, in the Andaman Sea and in the Bay of Bengal around $24 \mathrm{Ma}$ (Fig. 18d). Note also the sharp rise $(\times 5)$ of the SPAR in the Ganga foredeep.

In Indochina, the general shape of the SPAR curve is that of two successive plateaux followed by a period of acceleration at the end of the Cenozoic. The first plateau, until $37 \mathrm{Ma}$, corresponds to very low sediment accumulation rates (Fig. 17c). The basins of the Gulf of Thailand did not exist at that time, while to the north there was minor sedimentation in the Gulf of Tonkin. The Early Oligocene ( $\approx 37-30 \mathrm{Ma}$ ) was a period of opening of the basins surrounding the peninsula and coeval deposition that indicates erosion in the drainage basins onland, suggesting probable uplift. At that time compressive deformation took place in the Yulong Shan in Yunnan Province (Lacassin et al. 1996) in the Red River catchment. Left-lateral strike-slip motion occurred along the Wang Chao and Three Pagodas faults (Lacassin et al. 1997). Between 30 and $17 \mathrm{Ma}$, SPAR were approximately constant, defining the second plateau in Fig. 17(c). This period was coeval with the extension and opening of the South China Sea (Briais et al. 1993). This suggests the establishment of equilibrium between uplift and erosion rates, possibly because of lateral movements along the Red River fault (e.g. Leloup et al. 1995 and references therein). There was a continuous rise of the SPAR after the middle Miocene (17 Ma), the acceleration reaching a maximum between the upper Miocene and the Pliocene. The Quaternary, as was the case almost everywhere in Asia, was a period of maximum SPAR.

\subsection{Climate change and hydrology}

At the scale of continental Asia, there has been a continuous rise of SPAR since the onset of the collision at $50 \mathrm{Ma}$. This evolution of the rates of accumulation in Asian basins does not support a sudden change in climate induced by a sharp altitudinal threshold (Ramstein et al. 1997). However, this observation does not contradict regional evidence for rapid evolution of climate patterns and vegetation around 7-8 Ma such as the change (in photosynthesis) from $\mathrm{C} 3$ to $\mathrm{C} 4$ plants in Pakistan (Quade et al. 1989) or the appearance of radiolarians and foraminiferal fauna characteristic of upwelling in the Sea of Oman (Prell et al. 1992). At a regional scale (the size of large catchments $\approx 10^{6} \mathrm{~km}^{2}$ ) only the Andaman Sea and the Burman basins (Figs 18e-f), regions which experience strong 
monsoons at present, show sharp SPAR increases, doubling between the Late Miocene and the Pliocene. Because erosion also depends on precipitation (e.g. Milos 1980), this rise may be explained by the rapid development of a strong rainfallcontrolled erosional regime in these regions. At the scale of a basin, our results are in partial agreement with the results of Burbank et al. (1993): the SPAR in the Ganga foredeep slow down after the Miocene (Fig. 18c). Our data indicate, however, that they rise in the Bengal fan (Fig. 18d), whereas Burbank et al. (1993), solely on the basis of ODP legs, suggest they decrease after 8 Myr. In the Bengal foredeep the sediments are deltaic, with coarse deposits and a large sand fraction. In the distal part of the fan the sediments are fine muds. Nonetheless, assuming that this decrease of the wash load component in the distal part of the fan has some significance, then differences we observe may in fact reflect changes in the dynamic conditions that control the erosion and segregation mechanisms of the fine and coarse fractions of detritus delivered from the Himalaya. This would suggest a climatic control on the erosion/transport of fine and coarse fractions by rivers (Fluteau et al. 1999).

Although the development of monsoonal conditions is compatible with the sedimentary record on a regional basis, it is not clear that, at the scale of continental Asia, the general rise of the sediment SPAR in Asia should be controlled by such a sudden change in climate. In central Asia (Fig. 17b), for example, the SPAR accelerated, although the development of the Indian monsoon should not enhance erosion there (Luo \& Yanai 1983; Métivier \& Gaudemer 1997). The general trend of a continuous exponential rise in the SPAR in Asia does not correlate very well with Cenozoic climate changes and could, on geological timescales, be controlled mainly by tectonics and not by climate.

In the East China Sea, sediment accumulation began in the Palaeocene (66-58 Ma) and was coeval with extensional tectonics that affected all the basins. Rates of accumulation dropped sharply at the end of this period or during the Eocene. Two of the largest rivers of Asia at present discharge their yield into the East China Sea. This sediment originates mainly from the tectonically active Songpan Garze Range and the Tibetan highlands (Calassou 1994; Meyer 1991) where these rivers have their source. Did these rivers exist in the Palaeogene? What were the river courses? Did they flow more to the south, along the margins of Indochina, west Malaysia and Burma, as may be suggested by the shape of the headwaters of the Chang Jiang (Blue River)? These headwaters flow to the south for several hundred kilometres, almost reaching the drainage divides to the Mekong, Red and Pearl rivers. It seems clear that the present-day discharge sites of these rivers cannot be representative of the drainage prior to the beginning of the Pliocene (5 Ma) or Late Miocene (11 Ma). The strong oscillations and variations observed in the depositional patterns in the basins of East China and around Indochina imply variations in the flow and sediment loads of the rivers or important changes in the configuration of drainage in Asia.

\subsection{Recycling of the sediments of the Ganga plain}

At the scale of Asia, the sedimentary history is dominated by the Indo-Gangetic system and in particular by the Bengal fan, which accounts for approximately one-third to one-half of the total mass budget in the Cenozoic basins of Asia. Accumulation rates at the Asian scale appear to rise in a continuous manner, following an increasing exponential law and showing that on a regional scale clastic detrital sedimentation began more than $20 \mathrm{Myr}$ after of the onset of the India-Asia collision.

The Siwaliks originally formed the distal part of the Himalayan piedmont accumulation system and then became incorporated into the range, eroded, and hence recycled during the last 5 Myr (Lavé 1997). This raises the question of the importance of this recycling in the regional budgets. Assuming the average thickness of the sediment in front of the Himalaya to be less than $5 \mathrm{~km}$ along a $2000 \mathrm{~km}$ front (see Fig. 1) and knowing the present-day proportion of the India-Asia convergence accommodated by formation of the Himalayas $\left(2 \mathrm{~cm} \mathrm{yr}^{-1}\right)$, one can estimate that sediments are incorporated into the Siwalik prism at a maximum rate of $2 \times 10^{5} \mathrm{~km}^{3} \mathrm{Myr}^{-1}$ or $\approx 1.4 \times 10^{5} \mathrm{~km}^{3} \mathrm{Myr}^{-1}$ of solid phase. This corresponds to a maximum recycling rate for the sediments deposited in the Ganga foredeep. Most of these erosion products are carried to the Bengal fan where they ultimately accumulate. Correction for this recycling induces a reduction of the sharp rise of the SPAR during the Plio-Quaternary, leading to a much smoother and more continuous rise of the accumulation rates in the Bengal region since the beginning of the Miocene (Fig. 20). This may in part explain the difference we observe between our results and those of France-Lanord et al. (1993) who, on the basis of chemical analyses of DSDP drill cores in the distal part of the Bengal fan, suggested that there may even be a decrease in SPAR after 8 Ma. Even including the error bars our data indicate a rise of the SPAR in the Gange-Bengal accumulation system throughout the second half of the Cenozoic. The very clear change in the SPAR curve of the Bengal fan may be in part overestimated due to recycling of the Siwaliks. It might reflect the onset of movement along the Main Frontal Thrust and onset of a coupled active tectonic-climatic Siwalik cycle (Lavé 1997).

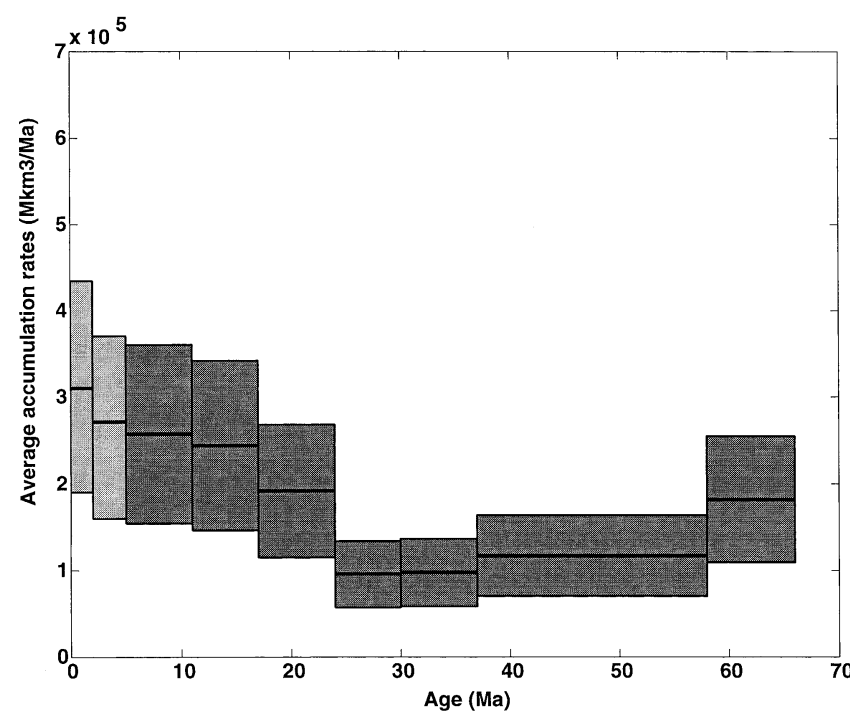

Figure 20. Average SPAR of the Bengal fan, roughly corrected for possible recycling of Siwalik sediments of the order of $1.4 \times 10^{5} \mathrm{~km}^{3} \mathrm{Myr}^{-1}$ during the last $5 \mathrm{Myr}$. 


\section{SUMMARY AND CONCLUSIONS}

In conclusion, this paper presents an attempt to derive information about orogenic processes from mass balance of the sedimentary basins located on the periphery of tectonically active mountain ranges. Using isopach data, cross-sections and stratigraphic columns, we applied simple geometric hypotheses to obtain a conservative estimate of the mass that accumulated in most of the major basins of Asia since the onset of the collision of India with Asia at approximately $50 \mathrm{Ma}$.

This mass budget shows that sedimentation in Asia started to rise rather late in the Cenozoic (after $37 \mathrm{Ma}$ ), whereas one would have expected it to start at the onset of the India-Asia collision. After $37 \mathrm{Ma}$ the general accumulation rates curve follows an exponential pattern, with Quaternary accumulation rates being maximal.

The delay and the overall shape of the curve could be related to a change in the proportions of the various deformation mechanisms in Asia during the collision. The simplest way to account for the shape of the SPAR curve is to have a progressive evolution from a period of dominant extrusion to one of dominant crustal thickening in the second half of the Cenozoic. The general SPAR curve shows no clear quantitative change in the erosion regime at 7-10 Ma that could be linked to the onset or strengthening of the monsoon. However, at the local scale, in regions that experience strong monsoons today, some obvious changes are observed at the end of the Miocene. These can be correlated with evidence for climate change around the Indian subcontinent (e.g. Quade et al. 1989; Prell et al. 1992). For Asia as a whole, it seems that tectonics is the dominant cause of the observed variations in the erosion/sedimentation system.

\section{ACKNOWLEDGMENTS}

This work benefited from discussions with J. Besse, F. Fluteau, J. Lavé, J. Marcoux and J. Van der Woerd. We acknowledge the useful comments by W. Hay, D. K. Rea and D. Burbank. This is IPGP contribution 1584 and INSU PROSE contribution 170. The database may be freely retrieved from http://www.ipgp. jussieu.fr/depts/TECTO/sedbas/sedimentarybasins.html

\section{REFERENCES}

Acharyya, S.K. \& Ray, K.K., 1982. Hydrocarbon possibilities of concealed Mesozoic-Paleogene sediments below Himalayan nappes-reappraisal, Am. Assoc. Petrol. Geol. Bull., 66, 57-70.

Ahnert, F., 1970. Functional relationships between denudation, relief, and uplift in large mid-latitude drainage basins, Am. J. Sci., 268, 243-263.

Alam, M., 1989, Geology and depositional history of Cenozoic sediments of the Bengal basin of Bangladesh, Palaeogeog. Palaeoclimat., Palaeoecol., 69, 125-139.

Armijo, R., Tapponnier, P., Mercier, J.-L. \& Tonglin, H., 1986 Quaternary extension in southern Tibet: field observations and tectonic implications, J. geophys. Res., 91, 13 803-13 872.

Armijo, R., Tapponnier, P. \& Tonglin, H., 1989. Late Cenozoic rightlateral strike-slip faulting in southern Tibet, J. geophys. Res., 94, 2787-2838.

ASCOPE (Asean Council on Petroleum), 1981. Tertiary Sedimentary Basins of the Gulf of Thailand and South China Sea: Stratigraphy, Structure and Hydrocarbon Occurences, ASEAN Council on Petroleum, Jakarta.
Avouac, J.-P. \& Burov, E.B., 1996, Erosion as a driving mechanism of intracontinental mountain growth, J. geophys. Res., 101, $17747-17769$.

Avouac, J.-P. \& Tapponnier, P., 1993. Kinematic model of active deformation in Central Asia, Geophys. Res. Lett., 20, 895-898.

Avouac, J.-P., Tapponnier, P., Bai, M., You, H. \& Wang, G., 1993. Active thrusting and folding along the northern Tien Shan and Late Cenozoic rotation of the Tarim relative to Dzungaria and Kazakhstan, J. geophys. Res., 98, 6755-6804.

Baldwin, B. \& Butler, C.O., 1985. Compaction curves, Am. Assoc. Petrol. Geol. Bull., 69, 622-626.

Beck, R.A. et al., 1995. Stratigraphic evidence for an early collision between northwest India and Asia, Nature, 373, 55-58.

Bender, F.K. \& Raza, H.A., eds, 1995. Geology of Pakistan, Beiträge zur regionalen Geologie der Erde, Vol. 25, Gebrüder Borntraeger, Berlin.

Besse, J. \& Courtillot, V., 1988. Paleogeographic maps of the continents bordering the Indian Ocean since the Early Jurassic, J. geophys. Res., 93, 11791-11808.

Besse, J. \& Courtillot, V., 1991. Revised and synthetic apparent polar path for the African, Eurasian North American and Indian plates and true polar wander since $200 \mathrm{Ma}$, J. geophys. Res., 96, 4029-4050.

Besse, J., Courtillot, V., Pozzi, J.P., Westphal, M. \& Zhou, Y.X., 1984. Paleomagnetic estimates of crustal shortening in the Himalayan thrust and Znagbo suture, Nature, 311, 621-626.

Bird, P., 1978. Initiation of intracontinental subduction in the Himalaya, J. geophys. Res., 83, 4975-4987.

Bird, P., 1979. Continental delamination and the Colorado plateau, J. geophys. Res., 84, 7561-7571.

Briais, A., Patriait, P. \& Tapponnier, P., 1993, Updated interpretation of magnetic anomalies and seafloor spreading stages in the South China Sea: implications for the Tertiary tectonics of southeast Asia, J. geophys. Res., 98, 6299-6328.

Buffalo, M., 1989. L'érosion des terres noires (marnes du Jurassique) dans la région du Buech (Hautes-Alpes, France), Thèse, Université Aix-Marseille III, France.

Burbank, D.W. \& Reynolds, R.G.H., 1984. Sequential late Cenozoic structural disruption of the northern Himalayan foredeep, Nature 311, 114-118.

Burbank, D.W., Derry, L.A. \& France-Lanord, C., 1993. Reduced Himalayan sediment production $8 \mathrm{Myr}$ ago despite an intensified monsoon, Nature, 364, 48-50.

Burbank, D.W., Leland, J., Fielding, E., Anderson, R.S., Brozovic, N., Reid, M.R. \& Duncan, C., 1996. Bedrock incision, rock uplift and threshold hillslopes in the northwestern Himalayas, Nature, 379, 505-510.

Burchfiel, B.C., Zhang, P., Wang, Y., Zhang, W., Song, F., Deng, Q., Molnar, P. \& Royden, L., 1991. Geology of the Haiyuan fault zone, Ningxia-hui autonomous region, China, and its relation to the evolution of the northeastern margin of the Tibetan Plateau, Tectonics, 10, 1091-1110.

Burg, J.-P., Davy, P. \& Martinod, J., 1995. Shortening of analogue models of the continental lithosphere: new hypothesis for the formation of the Tibetan plateau, Tectonics, 13, 475-483.

Calassou, S., 1994. Etude tectonique d'une chaîne de décollement, Thèse, Université Montpellier II, France.

Carbonnel, J.P., 1977. La limite de la plaque indienne en Afghanistan; nouvelles données géologiques et sismologiques, Mém. Soc. Géol. Fr., 8, 145-152.

CCOP (Committee for Co-ordination of joint Prospecting for mineral resources in Asian offshore areas), 1991. Tech. Bull., 23, ed. Hirayama, H., Komiyama, Tokyo.

Chamley, H., 1988. Les Milieux de Sédimentation, BRGM éditions, Orléans. 
Chen, S.C. \& Trenberth, K.E., 1988. Orographically forced planetary waves in the northern hemisphere winter: steady state model with wave-coupled lower boundary formulation, J. atmos. Sci., 45, 657-681.

Cochran, J., 1990. Himalayan uplift, sea level, and the record of Bengal Fan sedimentation, in Proc. ODP, Sci. Results, Vol. 116, pp. 397-414, eds Cochran, J., Stow, D. et al., Ocean Drilling Program, College Station, TX.

Cochran, J. \& Stow, D., eds, 1989. Bengal Fan. Shipboard Scientific Party, Site 717, in Proc. ODP Init. Repts, Vol. 116, pp. 397-414, eds Cochran, J. \& Stow, D., ODP, College Station, TX.

Cochran, J., Stow, D. et al., 1989. Proc. ODP, Init. Repts, Vol. 116, Ocean Drilling Program, College Station, TX.

Curray, J.R, 1991. Possible greenschist metamorphism at the base of a 22-km sedimentary sections, Bay of Bengal. Geology, 19, 1097-1100.

Curray, J.R., 1994. Sediment volume and mass beneath the Bay of Bengal, Earth. planet. Sci. Lett., 125, 371-383.

Davies, T.A., Kidd, R.B. \& Ramsay, A.T.S., 1995. A time-slice approach to the history of Cenozoic sedimentation in the Indian Ocean, Sed. Geol., 96, 157-179.

Defense Mapping Agency, 1992. Digital Chart of the World, Fairfax.

Delcaillau, B., 1992, Les Siwalik de l'Himalaya du Népal oriental, CRNS, Paris.

Einsele, G., Ratschbacher, L. \& Wetzel, E., 1996, The HimalayaBengal Fan denudation-accumulation system during the past $20 \mathrm{Ma}$, J. Geol., 104, 163-184.

England, P.C. \& Houseman, G., 1986. Finite strain calculations of continental deformation 2. Comparison with the India-Asia collision zone, J. geophys. Res., 91, 3664-3676.

England, P.C. \& Houseman, G.A., 1988. The mechanics of the Tibetan Plateau, in Tectonic Evolution of the Himalayas and Tibet, eds Shackleton, R.M., Dewey, J.F. \& Windley, B.F., Phil. Trans. R. Soc Lond., A326, 301-320.

England, P.H. \& McKenzie, D., 1982. A thin viscous sheet model for continental deformation, Geophys. J. R. astr. Soc., 70, 295-321.

ESCAP (Economic and Social Commission for Asia and the Pacific), 1978. ESCAP Atlas of Stratigraphy I, Burma, Malaysia, Thailand, Indonesia, Philippines, United Nations, New York.

ESCAP (Economic and Social Commission for Asia and the Pacific), 1985. ESCAP Atlas of Stratigraphy IV, People's Republic of China, United Nations, New York.

Fluteau, F., Ramstein, G. \& Besse, J., 1999. Evolution of the Asian and African monsoon in the past 30 million years using an AGCM J. geophys. Res., in press.

Fournier, F., 1960. Climat et Erosion. La Relation entre l'Érosion du Sol par l'Eau et les Précipitations Atmosphériques, Presses Universitaires de France, Paris.

France-Lanord, C., Derry, L. \& Michard, A., 1993. Evolution of the Himalaya since Miocene time: isotopic and sedimentological evidence from the Bengal Fan, in Himalayan Tectonics, eds Trealor, P.J. \& Searle, M.P., Geol. Soc. Spec. Publ., 74, 603-621.

Gallagher, K., 1989. An examination of some uncertainties associated with estimates of sedimentation rates and tectonic subsidence, Basin Res., 2, 97-114.

Ganser, A., 1964, Geology of the Himalayas, Interscience, Wiley, New York.

Gaudemer, Y., Tapponnier, P., Meyer, B., Peltzer, G., Guo, S.M., Chen, Z.T., Dai, H.G. \& Cifuentes, I., 1995. Partitioning of crustal slip between linked active faults in the Eastern Qilian Shan, and evidence for a major seismic gap, the Tianzhu gap, on the Western Haiyuan fault, Gansu (China), Geophys. J. Int., 120, 599-645.

Guong, Z., Jin, Q., Qiu, Z., Wang, S. \& Meng, J., 1989. Geology, tectonics and evolution of the Pearl River Mouth Basin, in Chinese Sedimentary Basins, Sedimentary Basins of the World, Vol. I, pp. 181-196, ed. Hsü, K., Elsevier, the Netherlands.

Hamilton, W., 1979. Tectonics of the Indonesian Region, USGS Prof. Pap., 1078.
Hanks, T.C., Bucknam, R.C., LaJoie, K.R. \& Wallace, R.E., 1984. Modification of wavecut and faulting-controlled landforms, J. geophys. Res., 89, 5771-5790.

Hay, W., Shaw, C. \& Wold, C., 1989. Mass-balanced paleogeographic reconstructions, Geol. Runds., 78, 207-242.

Ho, C.S, 1988. An Introduction to the Geology of Taiwan, Explanatory Text of the Geologic Map of Taiwan, Central Geological Survey, The Ministry of Economic Affairs, Taipai, Taiwan.

Howard, A.D. \& Kerby, G., 1983. Channel changes in Badlands, Geol. Soc. Am. Bull., 94, 739-752.

Hu, J., Xu, S., Tong, X. \& Wu, H., 1989. The Bohay Bay basin, in Chinese Sedimentary Basins, Sedimentary Basins of the World, Vol. I, pp. 89-105, ed. Hsü, K., Elsevier, the Netherlands.

Hutchinson, 1989. Geological Evolution of SE Asia, Oxford Scientific Publication, Oxford

Jaeger, J.J., Courtillot, V. \& Tapponnier, P., 1990. Paleontological view of the ages of the Deccan traps, the Cretaceous/Tertiary boundary, and the India-Asia collision, Geology, 17, 316-319.

Jin, Y., McNutt, M. \& Zhu, Y., 1994. Evidence from gravity and topography data for folding of Tibet, Nature, 371, 669-674.

Johnson, G.D., Opdyke, N.D., Tandon, S.K. \& Nanda, A.C., 1983. The magnetic polarity stratigraphy of the Siwalik Group at Haritalyangar (India) and a new last appearance datum for Ramapithecus and Sivapithecus in Asia, Palaeogeog., Palaeoclimat., Palaeoecol., 44, 223-249.

Khan, M.M.A, Ismail, M. \& Mansur, A., 1988. Geology and hydrocarbon prospect of the Surma Basin, Bangladesh, Offshore South East Asia Conference, 88-143, 365-388.

Kooi, H. \& Beaumont, C., 1994. Escarpment evolution on highelevation rifted margins: insight derived from a surface processes model that combines diffusion, advection and reaction, J. geophys. Res., 99, 12 191-12 209.

Kutzbach, J.E., Guetter, P.J., Ruddiman, W.F. \& Prell, W.L., 1989. The sensitivity of climate to late Cenozoic uplift in southeast Asia and the American Southwest: numerical experiments, J. geophys. Res., 94, $18393-18407$.

Lacassin, R., Shärer, U., Leloup, P.H., Arnaud, N., Tapponnier, P., Liu, X. \& Zhang, L., 1996. Tertiary deformation and metamorphism SE of Tibet: the folded Tiger-leap décollement of NW Yunnan, China, Tectonics, 15, 605-622.

Lacassin, R., Maluski, H., Leloup, P.H. \& Tapponnier, P., 1997. Tertiary deformation of the western margin of the extruded Indochina block: structural and 40Ar/39Ar evidence from NW Thailand, J. geophys. Res., 102, $10013-10037$.

Latif, M.A., 1964. Variations in abundance and morphology of pelagic foraminifera in the Palaeocene-Eocene of Rakhi Nala, West Pakistan, Geol. Bull. Univ. Punjab, 4, 29-109, Lahore.

Lavé, J., 1997. Tectonique et érosion: l'apport de la dynamique fluviale l'étude seismotectonique de l'Himalaya et du Népal central, Phd thesis, Université Paris 7.

Lee, K., 1985a. Geology of the Tarim Basin with special emphasis on petroleum deposits, Xinjiang Uygur Zizhiqu, Northwest China, USGS Open-file Rept, 85-616.

Lee, K., 1985b. Geology of the Petroleum and coal deposits in the Junggar (Zhungaer) basin, Xinjiang Uygur Zizhiqu, Northwest China, USGS Open-file Rept, 85-230.

Leeder, M.R., 1991. Denudation, vertical crustal movements and sedimentary basin fill, Geol. Runds., 80/2, 441-458.

Leloup, P.H. et al., 1995. The Ailao Shan-Red River shear zone (Yunnan, China), Tertiary transform boundary of Indochina, Tectonophysics, 251, 3.

Le Pichon, X., Fournier, M. \& Jolivet, L., 1992. Kinematics, topography, shortening and extrusion in the India-Eurasia collision, Tectonics, 11, 1085-1098.

Lindsay, J.F., Holliday, D.W. \& Hullbert, A.G., 1991. Sequence stratigraphy and the evolution of the Ganges-Brahmaputra Delta complex, Am. Assoc. Petrol. Geol. Bull., 75, 1233-1254. 
Luo, H. \& Yanai, M., 1983. The large-scale circulation and heat sources over the Tibetan Plateau and surrounding areas during the early summer of 1979. Part I: precipitation and kinematic analysis, Mon Weather Rev., 111, 922-944.

Maroof Khan, M.A., 1980. Bengladesh: a brief account on geology and hydrocarbon exploration, Oil Gas J., 182-186.

Masek, J.G, Isaacs, B.L., Gubbels, T.L. \& Fielding, E.J., 1994. Erosion and tectonics at the margin of continental plateaus, J. geophys. Res., 99, 13941-13956.

Mattauer, M., 1986. Intracontinental subduction, crust-mantle decollement and crustal stacking wedge in the Himalayas and other collision belts, in Collision Tectonics, eds Coward, M.P. \& Ries, A., Geol. Soc. Spec. Publ., 19, 37-50.

Métivier, F. \& Gaudemer, Y., 1997. Mass transfer between eastern Tien Shan and adjacent basins: constraints on regional tectonics and topography, Geophys. J. Int., 128, 1-17

Métivier, F., Gaudemer, Y., Tapponnier, P. \& Meyer, B., 1998. Northeastward growth of the Tibet plateau deduced from balanced reconstruction of two sedimentary basins: the Qaidam and Hexi corridor, Tectonics, 17, 823-842.

Meunier, M., ed., 1995. Compte-Rendu de Recherches, No. 3, BVRE de Draix, Cemagref edn, Antony, France.

Meyer, B., 1991. Mécanismes des grands tremblements de terre et du raccourcissement crustal oblique au bord nord-est du Tibet, Thèse de Doctorat, Université de Paris VII, France.

Meyer, B., Tapponnier, P., Bourjot, L., Métivier, F., Gaudemer, Y., Peltzer, G., Guo, S. \& Chen, Z., 1998. Crustal thickening in GansuQinghai, lithospheric mantle subduction, and oblique, strike-slip controlled growth of the Tibet plateau, Geophys. J. Int., 135, 1-47.

Milos, H., 1980. Erosion and Environment, in Environmental Sciences and Applications, Vol. 9, eds Biswas, A. \& Biswas, M.R., Pergamon Press, Oxford.

Mohan, M., 1985. Geohistory analysis of Bombay high region, Mar. Petrol. Geol., 2, 350-360.

Molnar, P. \& England, P., 1990. Late Cenozoic uplift of mountain ranges and global climate change: chicken or egg?, Nature, 346, 29-34.

Molnar, P. \& Tapponnier, P., 1975. Cenozoic tectonics of Asia: effects of a continental collision, Science, 189, 419-426.

Molnar, P. \& Tapponnier, P., 1978. Active tectonics of Tibet, J. geophys. Res., 83, 5361-5375.

Molnar, P., England, P. \& Martinod, J., 1993. Mantle dynamics, uplift of the Tibetan Plateau, and the Indian monsoon, Rev. Geophys., 31, 357-396.

Montgomery, D.R., 1994. Valley incision and the uplift of mountain peaks, J. geophys. Res., 99, 13913-13921.

Odin, G.S., 1994. Geological time scale, C. R. Acad. Sci., 318, 59-71.

Palmer, A.R., 1983. A decade of North American geology, 1983 time scale, Geology, 11, 503-504

Patriat, P. \& Achache, J., 1984. India/Asia collision chronology has implications for crustal shortening and driving mechanism of plates, Nature, 311, 615-621.

Peltzer, G. \& Saucier, F., 1996. Present-day kinematics of Asia derived from geologic fault rates, J. geophys. Res., 101, 27943-27956.

Peltzer, G. \& Tapponnier, P., 1988. Formation and evolution of strikeslip faults, rifts, and basins during the India-Asia collision: an experimental approach, J. geophys. Res., 93, 15 095-15117.

Pinet, P. \& Souriau, M., 1988. Continental erosion and large-scale relief, Tectonics, 7, 563-582.

Pradidtan, S. \& Dook, R., 1992. Petroleum geology of the northern part of the gulf of Thailand, in National Conference on Geologic Resources of Thailand: Potential for Future Development, pp. 235-246, 17-24 November, Dept Min. Res., Bangkok, Thailand.

Prell, W.L., Murray, D.W., Clemens, S.C. \& Anderson, D.M., 1992. Evolution and variability of the Indian Ocean summer monsoon: evidence from the western Arabian Sea drilling, in Synthesis of Results from Scientific Drilling in the Indian Ocean, eds
Duncan, R.A., Rea, D.K., Kidd, R.B., von Rad, U. \& Weissel, J.K., Am. geophys. Un. Geophys. Monogr., 70, 447-469.

Quade, J., Cerling, T. \& Bowman, J., 1989. Development of Asian monsoon revealed by marked ecological shift during the latest Miocene in northern Pakistan, Nature, 342, 163-166.

Rabinowitz, P.D., Dipiazza, N. \& Matthias, P.K., 1988. Sediment Thickness Map of the Indian Ocean, AAPG, Tulsa.

Ramstein, G., Fluteau, F., Besse, J. \& Joussaume, S., 1997. Effect of orogeny, plate motion and land-sea distribution on Eurasian climate change over the past 30 million years, Nature, 386, 788-795.

Rea, D.K., 1992. Delivery of Himalayan sediment to the northern Indian Ocean and its relation to global climate, sea level, uplift, and seawater strontium, in Synthesis of Results from Scientific Drilling in the Indian Ocean, eds. Duncan, R.A., Rea, D.K., Kidd, R.B. von Rad, U. \& Weissel, J.K., Am. geophys. Un. Geophys. Monogr., 70, 387-402.

Reimann, K.-U., 1993. Geology of Bangladesh, Beiträge zur regionalen Geologie der Erde, Gebrüder Borntraeger, Berlin.

Sastri, V.V., Bhandari, L.L., Raju, A.T.R. \& Datta, A.K., 1971. Tectonic framework and subsurface stratigraphy of the Ganga Basin, J. geol. Soc. India, 12, 222-233.

Schumm, S., Mosley, M. \& Weaver, W., 1987. Experimental Fluvial Geomorphology, John Wiley \& Sons, New York.

Summerfield, M.A. \& Hulton, N.J., 1994. Natural controls of fluvial denudation rates in major world drainage basins, J. geophys. Res., 99, $13871-13883$.

Sun, D. \& Leibo, W., 1984. Tectonic Systems Map of the People's Republic of China and Adjacent Sea Area, Cartographic Publishing House, Beijing.

Tapponnier, P. \& Molnar, P., 1977, Active tectonics and faulting of China, J. geophys. Res., 82, 2905-2930.

Tapponnier, P. \& Molnar, P., 1979. Active faulting and Cenozoic tectonics of the Tien Shan, Mongolia and Baykal regions, J. geophys. Res., 84, 3425-3459.

Tapponnier, P., Peltzer, G. \& Armijo, R., 1986. On the mechanics of the collision between India and Asia, in Collision Tectonics, eds Coward, M.P. \& Ries, A., Geol. Soc. Spec. Publ., 19, 115-157.

Tapponnier, P. et al., 1990. Active thrusting and folding in the Qilian Shan, and decoupling between upper crust and mantle in northeastern Tibet, Earth. planet. Sci. Lett., 97, 382-403.

Tucker, G.E. \& Slingerland, R., 1994. Erosional dynamics, flexural isostasy, and long-lived escarpments: a numerical modeling, J. geophys. Res., 99, 12229-12243.

Vlassov, N.G. \& Diakov, Y.A., 1984. Geologic Map of the Soviet Socialist Republic of Tadjikhistan, 1:500 000, Ministry of Geology of USSR, Moscow.

Von der Borsch, Sclater, J.G., et al., 1974. Init. Repts DSDP, Vol. 22 US Govt Printing Office, Washington.

Weldon, R.J. \& Sieh, K.E., 1985. Holocene rate of slip and tentative recurrence interval for large earthquakes on the San Andreas fault in Cajon Pass, Southern California, Geol. Soc. Am. Bull., 96, 793-812.

Whitmarsh, R.B., Weser, O.E., Ross, D.A., et al., 1974. Init. Repts $D S D P$, Vol. 23, US Govt Printing Office, Washington.

Willgoose, G.R., Bras, R.L. \& Rodriguez-Iturbe, I., 1991. A physically based coupled network growth and hillslope evolution model, 1. Theory, Water Res. Res., 27, 1671-1684.

Yang, Z. \& Besse, J., 1993. Paleomagnetic study of Permian and Mesozoic sedimentary rocks from northern Thailand supports the extrusion model for Indochina, Earth. planet. Sci. Lett., 117, 525-552.

Ye, H., Shedlock, K.M., Hellinger, S.J. \& Sclater, J.G., 1985. The North China basin: and example of a Cenozoic rifted intraplate basin, Tectonics, 4, 153-169.

Zhang, J., 1985. Huabei-Bohaiwan Basin, in ESCAP Atlas of Stratigraphy IV: People's Republic of China, United Nations, Stratigraphic Correlation between Sedimentary Basins of the ESCAP Region, Vol. X, pp. 22-27, Min. Res. Development Series 52, New York. 
Zhang, Q. \& Kou, C., 1989. Petroleum geology of Cenozoic basins in the northwestern continental shelf, South China Sea, in Chinese Sedimentary Basins, Sedimentary Basins of the World, Vol. I, pp. 197-206, ed. Hsü, K., Elsevier, the Netherlands.

Zhao, J., You, Y. \& Zhou, X., 1985. Subei-South Yellow Sea Basin, in ESCAP Atlas of Stratigraphy IV: People's Republic of China, United Nations, Stratigraphic Correlation between Sedimentary Basins of the ESCAP Region, Vol. X, pp. 28-34, Min. Res. Development Series 52, New York.

Zhao, W.L. \& Morgan, W.J., 1985. Uplift of the Tibetan plateau, Tectonics, 4, 359-369.
Zhong, S., 1985. Pearl River Mouth Basin of South China Sea, in ESCAP Atlas of Stratigraphy IV: People's Republic of China, United Nations, Stratigraphic Correlation between Sedimentary Basins of the ESCAP Region, Vol. X, pp. 45-49, Min. Res. Development Series 52, New York.

Zhou, Z., Zhao, J. \& Yin, P., 1989. Characteristic and tectonic evolution of the East China Sea, in Chinese Sedimentary Basins Sedimentary Basins of the World, Vol. I, pp. 165-180, ed. Hsü, K., Elsevier, the Netherlands.

Zhu, Z., ed., 1990. Quaternary Geologic Map of the Peoples Republic of China and Adjacent Sea Area, China Cartographic Publishing House, Beijing, China. 